Universidade de Brasília - UnB

Instituto de Ciências Humanas - IH

Departamento de Geografia - GEA

Programa de Pós Graduação em Geografia

UNIVERSIDADE DE BRASÍLIA

PÓS-GRADUÇÃO EM GEOGRAFIA

\title{
AVALIAÇÃO DAS MUDANÇAS ESPACIAIS E TEMPORAIS NA COBERTURA DA TERRA DA APA DO RIO SÃO BARTOLOMEU (DISTRITO FEDERAL - BRASIL) APÓS TRINTA ANOS DE CRIAÇÃO
} (1984 - 2014) 
Universidade de Brasília

Instituto de Ciências Humanas

Departamento de Geografia

Programa de Pós Graduação em Geografia

UNIVERSIDADE DE BRASÍLIA

PÓS-GRADUÇÃO EM GEOGRAFIA

\title{
AVALIAÇÃO DAS MUDANÇAS ESPACIAIS E TEMPORAIS NA COBERTURA DA TERRA DA APA DO RIO SÃO BARTOLOMEU (DISTRITO FEDERAL - BRASIL) APÓS TRINTA ANOS DE CRIAÇÃO
} (1984 - 2014)

\author{
Alisson Santos Neves \\ Orientador: Prof. Dr. Osmar Abílio de Carvalho Júnior \\ Co-orientador: Prof. Dr. Sandro Nunes de Oliveira
}

Dissertação de Mestrado

Brasília-DF, setembro de 2016. 


\section{AVALIAÇÃO DAS MUDANÇAS ESPACIAIS E TEMPORAIS NA COBERTURA DA TERRA DA APA DO RIO SÃO BARTOLOMEU (DISTRITO FEDERAL - BRASIL) APÓS TRINTA ANOS DE CRIAÇÃO} (1984 - 2014)

\section{Alisson Santos Neves}

Dissertação de Mestrado submetida ao Departamento de Geografia da Universidade de Brasília, como parte dos requisitos para a obtenção do Grau de Mestre em Geografia, área de concentração Gestão Ambiental e Territorial, linha de pesquisa Geoprocessamento, opção Acadêmica.

Aprovado por:

Prof. Dr. Osmar Abílio de Carvalho Júnior, Doutor (UnB)

Orientador

Prof. Dr. Sandro Nunes de Oliveira, Doutor (IFB)

Co-orientador

Prof. Dr. Roberto Arnaldo Trancoso Gomes, Doutor (UnB)

Examinador Interno

Prof. Dr. Jeater Waldemar Maciel Correa Santos, Doutor (UFMT) Examinador Externo

Brasília (DF), 30 de setembro de 2016. 


\section{FICHA CATALOGRÁFICA}

\section{NEVES, ALISSON SANTOS}

Avaliação das mudanças espaciais e temporais na cobertura da Terra da APA do Rio São Bartolomeu (Distrito Federal - Brasil) após trinta anos de criação (1984 2014), 83p, 297 mm, (UnB-GEA, Mestre em Gestão Ambiental e Territorial, 2016).

Dissertação de Mestrado - Universidade de Brasília. Departamento de Geografia.

1. Séries Temporais

3. Detecção de Mudanças

4. UnB-IH-GEA
2. LANDSAT

4. Sensoriamento Remoto

5. Fragmentação da paisagem

\section{REFERÊNCIA BIBLIOGRÁFICA}

NEVES, A. S.; Avaliação das mudanças espaciais e temporais na cobertura da Terra da APA do Rio São Bartolomeu (Distrito Federal - Brasil) após trinta anos de criação (1984 - 2014); 83p; Dissertação (Mestrado em Geografia) Universidade de Brasília; Brasília - DF; 2016.

\section{CESSÃO DE DIREITOS}

É concebido à Universidade de Brasília - UnB permissão para reproduzir cópias desta dissertação e emprestar ou vender tais cópias somente para propósitos acadêmicos e científicos. O autor reserva outros direitos de publicação e nenhuma parte desta dissertação de mestrado pose ser reproduzida sem a autorização por escrito do autor. 


\section{DEDICATÓRIA}

Dedico este trabalho aos meus pais Wilson Neves e Marlete Neves, ao meu Irmão Fabrício Neves, meu sobrinho Heitor Neves, minha esposa Kali Cerqueira, a nossa filha Sarah que está a caminho e as pessoas com deficiência ... É possível! 


\section{AGRADECIMENTOS}

Agradeço a Deus, pela luz e discernimento para sobrepor os momentos adversos, possibilitando vitórias que contribuem para o meu amadurecimento e evolução espiritual.

A minha família, que me concedeu a estrutura necessária para obter sucesso na vida pessoal e profissional. Aos meus pais Wilson Neves e Marlete Neves, ao meu Irmão Fabrício Neves e minha esposa Kali Cerqueira.

Ao Prof. Dr. Osmar Abílio de Carvalho Júnior, pela orientação, incentivo, paciência e compreensão. Assim como ao Prof. Dr. Sandro Nunes de Oliveira, pelo apoio, atenção, cuidado e disponibilidade.

A Universidade de Brasília - UnB, em especial ao Departamento de Geografia pela oportunidade e estrutura para o desenvolvimento deste trabalho.

A Universidade Estadual de Santa Cruz - UESC (Ilhéus-BA), pela qualidade do Curso de Agronomia, que me possibilitou a construção de uma base para cursar o mestrado e realizar o presente trabalho.

Ao Instituto Brasília Ambiental - IBRAM, por permitir uma contínua evolução profissional, através do desafio de viabilizar tecnicamente o desenvolvimento sustentável nos imóveis rurais do Distrito Federal.

Aos amigos do IBRAM, Amanda Porto, Ana Gabriela Ortiz, Daniel Inácio, Daniella Castanheira, Dilberto Batista, Fernando Costa, José Flávio dos Santos, Juliana de Castro, Natanael Abade, Petrônio Diego e Tatiane Correia, pelo apoio, incentivo, atenção, disponibilidade, carinho e amizade.

Por fim, as minhas companheiras "muletas", grandes professoras, que mesmo sem pronunciar uma palavra ou indicar um livro, são parte fundamental do meu amadurecimento espiritual, pessoal e profissional. 


\section{SUMÁRIO}

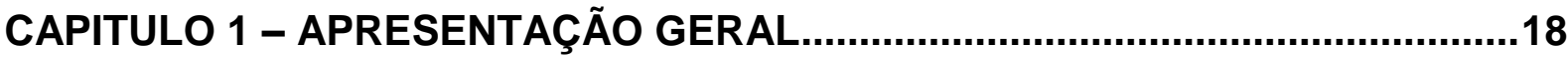

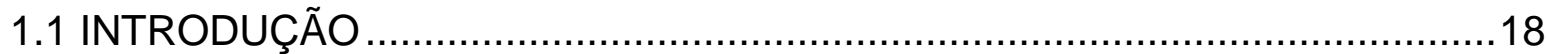

1.2 ANÁLISE DE SÉRIES TEMPORAIS E DETECÇÃO DE MUDANÇAS ............23

1.3 CARACTERÍSTICAS DO SENSOR LANDSAT TM …...............................24

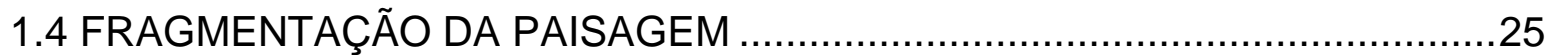

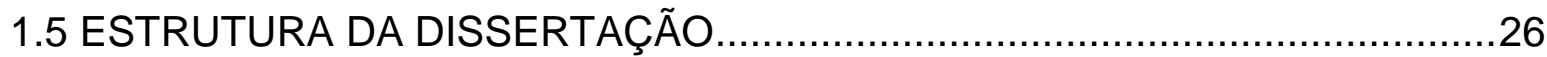

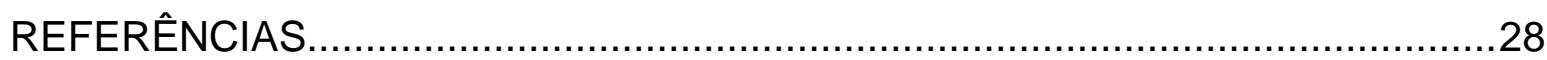

CAPÍTULO 2 - ANÁLISE MULTITEMPORAL DA PERDA DE VEGETAÇÃO NATIVA NA APA DO RIO SÃO BARTOLOMEU - DISTRITO FEDERAL - BRASIL

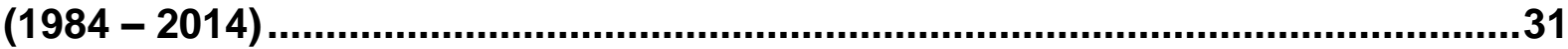

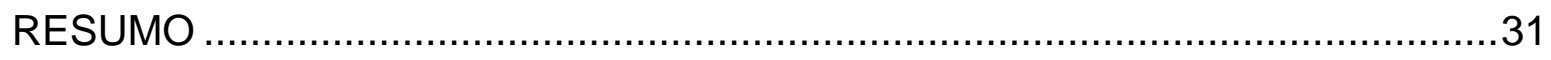

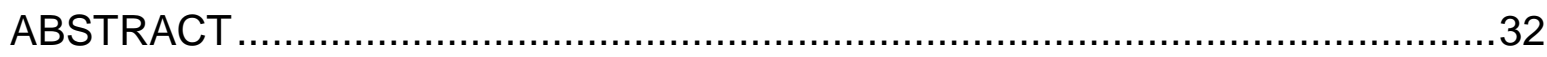

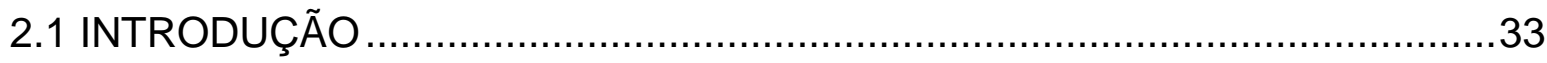

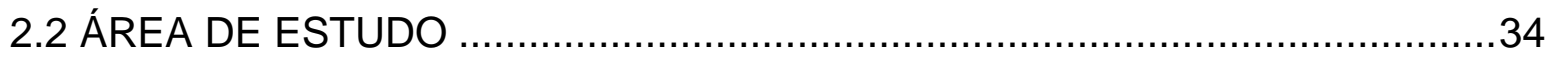

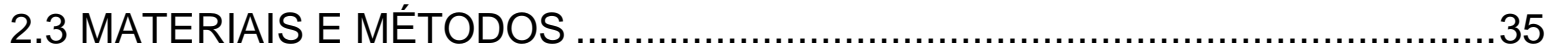

2.3.1 Imagens de Aerofotos e Landsat 5 TM do Distrito Federal ........................35

2.3.2 Classificação do uso e cobertura da Terra por interpretação visual ...........36

2.3.3 Detecção de mudanças pelo método de pós-classificação .........................37

2.3.4 Fatores que controlam as atividades antrópicas.......................................38

2.4 RESULTADOS

2.4.1 Resultados da evolução temporal do uso e cobertura da Terra .................38

2.4.2 Resultados da deteç̧ão de mudanças ...................................................43

2.4.3 Fatores que condicionam a ocupação humana .......................................48

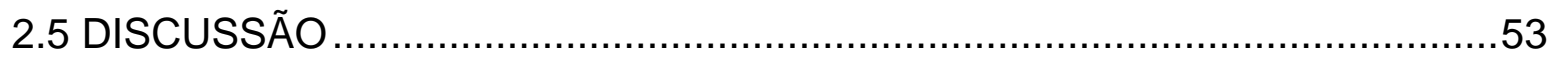

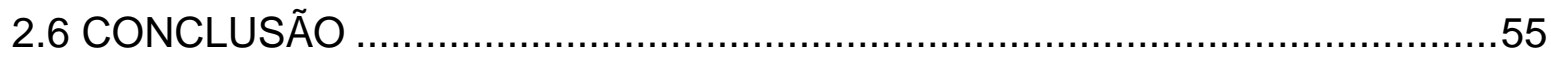

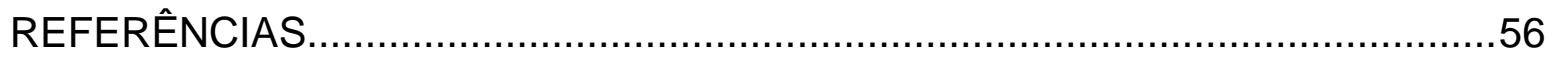


CAPÍTULO 3 - ANÁLISE DA FRAGMENTAÇÃO DA PAISAGEM NA APA DO RIO SÃO BARTOLOMEU - DISTRITO FEDERAL - BRASIL (1984 - 2014)..................59

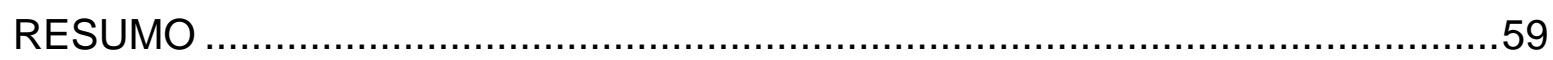

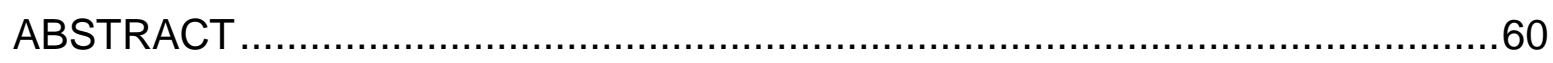

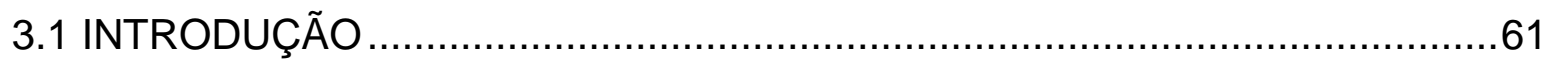

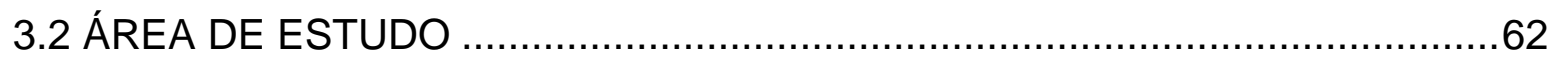

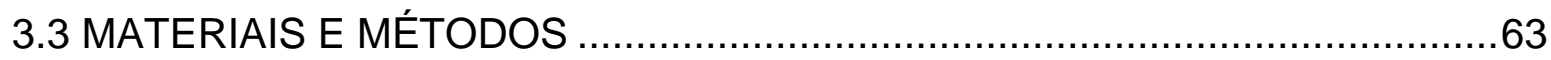

3.3.1. Classificação multitemporal do uso e cobertura da Terra ...........................63

3.3.2 Análise das métricas tradicionais de Paisagem ........................................64

3.3.3 Análise Morfológica do Padrão Espacial (Morphological Spatial Pattern

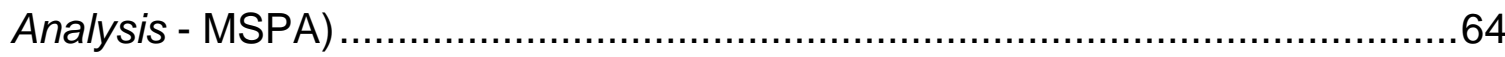

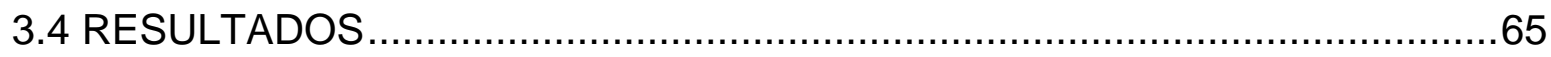

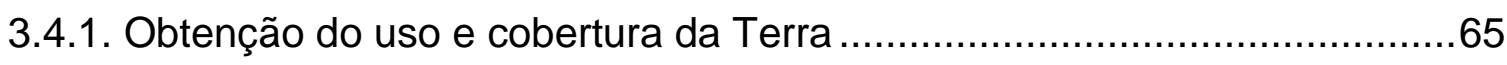

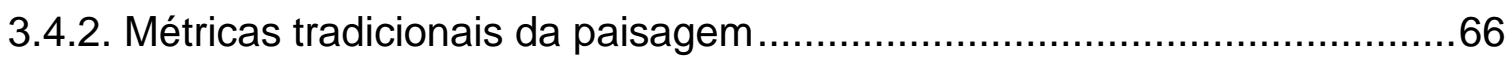

3.4.3. Análise Morfológica do Padrão Espacial (MSPA) ....................................68

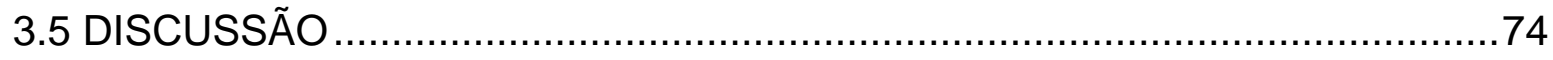

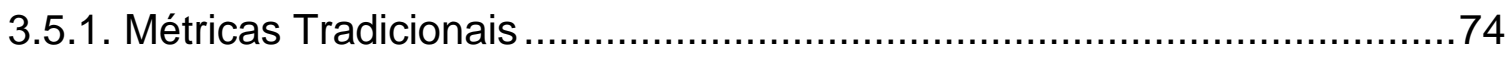

3.5.2. Análise Morfológica do Padrão Espacial (MSPA) ………............................75

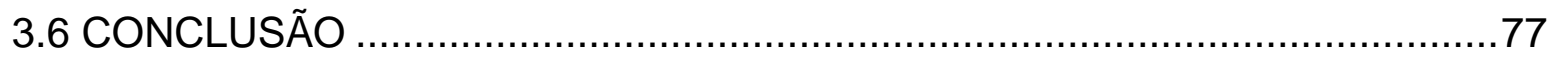

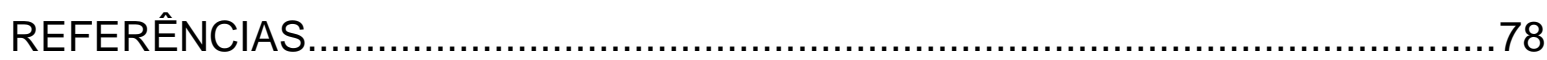

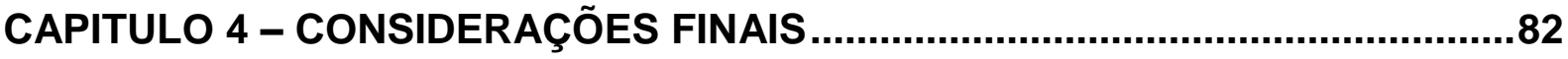




\section{LISTA DE FIGURAS}

Figura 1.2: Fluxograma da Dissertação. .26

Figura 2.1 - Mapa de localização da Área de Proteção Ambiental do Rio São Bartolomeu.

Figura 2.2 - Cobertura do solo da APA do Rio São Bartolomeu 2014 (a), 2011 (b), 2008 (c), 2005 (d), 2002 (e), 1999 (f), 1996 (g), 1993 (h), 1990 (i), 1987 (j) e 1984 (l).

Figura 2.3 - Dinâmica do Uso e Cobertura da Terra na APA do Rio São Bartolomeu entre 1984 a 2014. 41

Figura 2.4 - Áreas Alteradas na APA do Rio São Bartolomeu. 42

Figura 2.5 - Escalada reservatórios artificiais na APA do Rio São Bartolomeu. 42

Figura 2.6 - Gráfico com as porcentagens das classes vegetação nativa, agrossilvipastoril, área alterada e área urbana.

Figura 2.7 - Mapas de detecção (a) e padrões (b) de mudanças da vegetação natural na área de estudo entre os períodos do mapeamento.

Figura 2.8 - Análise de declividade da região de estudo. 49

Figura 2.9 - Relação de declividade com a manutenção de vegetação natural. 49

Figura 2.10 - Correlação do uso agrícola com a propriedade dos imóveis rurais.....50

Figura 2.11 - Macrozona Urbana na APA do Rio São Bartolomeu. .51

Figura 2.12 - Zonas de maior restrição ambiental na Área de Proteção Ambiental do Rio São Bartolomeu. .52

Figura 2.13 - Zonas de maior restrição ambiental na APA do Rio São Bartolomeu. 53 Figura 3.1 - Mapa de localização da Área de Proteção Ambiental do Rio São Bartolomeu. 63

Figura 3.2 - Dinâmica das mudanças da cobertura da terra na APA do Rio São Bartolomeu.

Figura 3.3 - Métricas tradicionais da área de estudo no período de 1984 à 2014: (a) CA, (b) TE, (c) MPE, (d) MPS, (e) NumP, (f) PSSD, (g) MSI e (h) MNNDist ....

Figura 3.4 - MSPA da vegetação natural existente em 1984, com bordas de (a) 30m, (b) $60 \mathrm{~m}$, (c) $90 \mathrm{~m}$ e (d) $120 \mathrm{~m}$. 69

Figura 3.5 - MSPA da vegetação natural existente em 2014, com bordas de (a) 30m, (b) $60 \mathrm{~m}$, (c) $90 \mathrm{~m}$ e (d) $120 \mathrm{~m}$. 70

Figura 3.6 - MSPA em percentagem da área de estudo no período de 1984 à 2014: (a) Core, (b) Islet, (c) Edge, (d) Perforation, (e) Bridge, (f) Loop e (g) Branch. .71 
Figura 3.7 - MSPA em frequência no período de 1984 à 2014: (a) Core, (b) Islet, (c) Edge, (d) Perforation, (e) Bridge, (f) Loop e (g) Branch. ......................................72 


\section{LISTA DE TABELAS}

Tabela 1.1: Grupos, categorias, tipo de posse e usos permitidos por lei em unidades de conservação no Brasil.

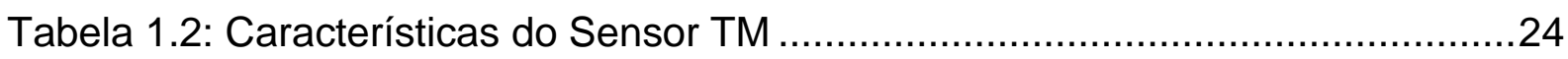

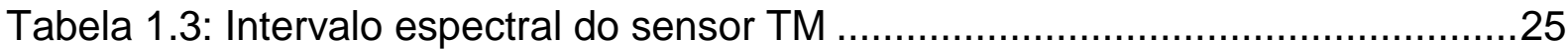

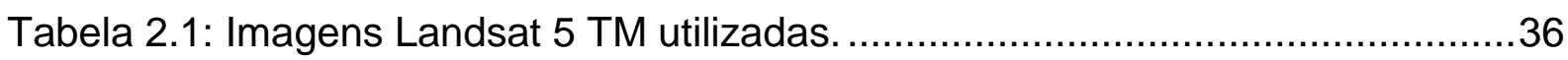

Tabela 2.2: Evolução temporal do uso e cobertura da terra na Área de Proteção Ambiental do Rio São Bartolomeu (hectares e porcentagem), considerando as seguintes classes: vegetação natural (VN), agrossilvipastoril (AgP), área alterada (AA), área urbana (AUrb) e água.

Tabela 2.4: Detecção de mudança das classes de vegetação natural (VN), agrossilvipastoril (AgP), área alterada (AA), área urbana (AUrb), água e estrada de 1984 a 1987.

Tabela 2.5: Detecção de mudança das classes de vegetação natural (VN), agrossilvipastoril (AgP), área alterada (AA), área urbana (AUrb), água e estrada de 1987 a 1990.

Tabela 2.6: Detecção de mudança das classes de vegetação natural (VN), agrossilvipastoril (AgP), área alterada (AA), área urbana (AUrb), água e estrada de 1990 a 1993.

Tabela 2.7: Detecção de mudança das classes de vegetação natural (VN), agrossilvipastoril (AgP), área alterada (AA), área urbana (AUrb), água e estrada de

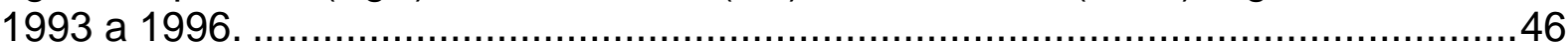

Tabela 2.8: Detecção de mudança das classes de vegetação natural (VN), agrossilvipastoril (AgP), área alterada (AA), área urbana (AUrb), água e estrada de 1996 a 1999.

Tabela 2.9: Detecção de mudança das classes de vegetação natural (VN), agrossilvipastoril (AgP), área alterada (AA), área urbana (AUrb), água e estrada de 1999 a 2002.

Tabela 2.10: Detecção de mudança das classes de vegetação natural (VN), agrossilvipastoril $(\mathrm{AgP})$, área alterada $(\mathrm{AA})$, área urbana (AUrb), água e estrada de 2002 a 2005

Tabela 2.11: Detecção de mudança das classes de vegetação natural (VN), agrossilvipastoril $(\mathrm{AgP})$, área alterada $(\mathrm{AA})$, área urbana (AUrb), água e estrada de 2005 a 2008.

Tabela 2.12: Detecção de mudança das classes de vegetação natural (VN), agrossilvipastoril $(\mathrm{AgP})$, área alterada (AA), área urbana (AUrb), água e estrada de 2008 a 2011. 
Tabela 2.13: Detecção de mudança das classes de vegetação natural (VN), agrossilvipastoril $(\mathrm{AgP})$, área alterada $(\mathrm{AA})$, área urbana (AUrb), água e estrada de 2011 a 2014. 


\section{LISTA DE ABREVIATURAS E SIGLAS}

$\begin{array}{ll}\text { AA } & \text { Área Alterada } \\ \text { AgP } & \text { Agrossilvipastoril } \\ \text { APA } & \text { Área de Proteção Ambiental } \\ \text { APP } & \text { Área de Preservação Permanente } \\ \text { AUrb } & \text { Área Urbana } \\ \text { BA } & \text { Bahia } \\ \text { CA } & \text { Área de classe } \\ \text { CAR } & \text { Cadastro Ambiental Rural } \\ \text { DF } & \text { Distrito Federal } \\ \text { ERTS-1 } & \text { Earth Resources Technological Satellite } \\ \text { EPASBR } & \text { Environmental Protected Area of São Bartolomeu River } \\ \text { FLONA } & \text { Floresta Nacional } \\ \text { IBRAM } & \text { Instituto Brasília Ambiental } \\ \text { IFB } & \text { Instituto Federal de Brasília } \\ \text { INPE } & \text { Instituto Nacional de Pesquisas Espaciais } \\ \text { LANDSAT } & \text { Land Remote Sensing Satellite } \\ \text { MG } & \text { Minas Gerais } \\ \text { MMA } & \text { Ministério do Meio Ambiente } \\ \text { MNNDist } & \text { Distância média do vizinho mais próximo } \\ \text { MODIS } & \text { Moderate Resolution Imaging Spectroradiometer } \\ \text { MPAR } & \text { Índice de Proporção Média do Perímetro-Área } \\ \text { MPE } & \text { Tamanho médio das bordas } \\ \text { MPS } & \text { Área Média dos Fragmentos } \\ \text { MPS } & \text { Tamanho médio dos fragmentos } \\ & \end{array}$




$\begin{array}{ll}\text { MSI } & \text { Índice de Forma Média } \\ \text { MSI } & \text { índice de forma média } \\ \text { MSPA } & \text { Morphological Spatial Pattern Analysis } \\ \text { NumP } & \text { Número de Fragmentos } \\ \text { PDOT } & \text { Plano Diretor de Ordenamento Territorial do Distrito Federal } \\ \text { PI } & \text { Piauí } \\ \text { PR } & \text { Paraná } \\ \text { PRA } & \text { Programa de Regularização Ambiental } \\ \text { PSCoV } & \text { Coeficiente de Variação dos Fragmentos } \\ \text { PSSD } & \text { Desvio Padrão do Tamanho dos Fragmentos } \\ \text { PSSD } & \text { Desvio padrão do tamanho dos fragmentos } \\ \text { RA } & \text { Região Administrativa } \\ \text { SEGETH } & \text { Secretaria de Estado de Gestão do Território e Habitação do Distrito } \\ \text { SIRGAS } & \text { Federal } \\ \text { SisNAMA } & \text { Sistema de Referência Geocêntrico para as Américas } \\ \text { SNUC } & \text { Sistema Nacional de Unidades de Conservação } \\ \text { TE } & \text { Total das bordas } \\ \text { TERRACAP } & \text { Agencia de Desenvolvimento do Distrito Federal } \\ \text { TM } & \text { Thematic Mapper } \\ \text { UC } & \text { Unidade de Conservação } \\ \text { UnB } & \text { Universidade de Brasília } \\ \text { V-Late } & \text { Vector-based landscape analysis tools extension } \\ \text { VN } & \text { Vegetação Natural } \\ \text { ZCI } & \text { Zona de Convergência Intertropical } \\ \text { Zona de Conservação de Vida Silvestre } \\ \text { Ziente }\end{array}$


ZPVS Zona de Preservação de Vida Silvestre

ZUR Zona de Uso Restrito

ZVS Zona de Vida Silvestre 


\section{RESUMO}

Para viabilizar a correta implementação da política ambiental brasileira é necessário conhecer o território, compreendendo as modificações impostas pelo homem ao longo dos anos. Para tal, estão disponíveis tecnologias como o sensoriamento remoto, que é um conjunto de atividades que permitem a coleta de informações dos objetos que compõem a superfície terrestre sem a necessidade de contato direto com os mesmos. A proteção ambiental está diretamente relacionada a conservação e uso sustentável dos remanescentes de vegetação nativa, para a manutenção da água, preservação da fauna e flora, além da estabilidade geológica. Nesse sentido, estudou-se a APA do Rio São Bartolomeu (82.679,88ha), que é uma unidade de uso sustentável, avaliando a mudanças espaciais e temporais na cobertura da Terra, compreendendo a dinâmica da antropização ao longo dos anos, utilizando técnicas de sensoriamento remoto através de fotografia aérea de alta resolução espacial $(0,23 \mathrm{~m})$, obtido por levantamento realizado pelo Governo do Distrito Federal em 2014, e série temporal do sensor Landsat 5 TM, órbita 221 ponto 71, dos anos de 1984, 1987, 1990, 1993, 1996, 1999, 2002, 2005, 2008 e 2011, realizando interpretação visual, com posterior análise de detecção de mudanças através da tabulação cruzada e métricas de fragmentação da paisagem. $O$ estudo concluiu que a área de objeto da análise sofreu durante os primeiros trinta anos com a pressão antrópica, principalmente pelo interesse imobiliário, seja para uso rural ou urbano, em detrimento aos remanescentes de vegetação nativa, que perderam $15.775,83 \mathrm{ha}$, representando $18,80 \%$ do território desta área protegida, assim como, fez as manchas de vegetação nativa saírem de 597 em 1984 para 808 em 2014, evidenciando um esfacelamento dos blocos de vegetação natural, através de uma fragmentação que se deu de forma gradual e pontual, destacando as perfurações, que precederam o desaparecimento da vegetação silvestre. Referente à política pública, destaca-se o previsto no PDOT-2009 (Lei Complementar no803/2009), que encaminha $25,59 \%$ da APA do Rio São Bartolomeu a urbanização, colocando em risco a manutenção de $6.033,82$ ha de vegetação natural que em 2014 estavam na área urbanizável, por outro lado, a Lei n⒌344/2014, elevou para $45,86 \%$ a área de maior restrição ambiental nesta unidade de conservação, abrigando $72,80 \%$ da vegetação natural existente em 2014.

Palavras Chaves: Detecção de mudanças, Fragmentação da paisagem, APA do Rio São Bartolomeu. 


\begin{abstract}
To enable the proper implementation of the Brazilian environmental policy is necessary to know the territory, including changes imposed by man over the years. To this end, available technologies such as remote sensing, which is a set of activities that allow the collection of information objects that make up the earth's surface without the need for direct contact with them. Environmental protection is directly related to conservation and sustainable use of remaining native forest, for the maintenance of water, preservation of wildlife, as well as geological stability. In this sense, the Environmental Protected Area of São Bartolomeu River - EPASBR $(82.679,88 \mathrm{ha})$, an area of sustainable use, was studied, evaluating the spatial and temporal changes in land cover, including the dynamics of human disturbance over the years, using remote sensing techniques with high spatial resolution aerial photography $(0.23 \mathrm{~m})$, obtained by a survey conducted by the Government of the Federal District, Brazil, in 2014, and time series of Landsat 5 TM sensor, orbit 221 point 71, the years $1984,1987,1990,1993,1996,1999,2002,2005,2008$ and 2011, performing visual interpretation with subsequent change detection analysis by cross tabulation and landscape fragmentation metrics. The study concluded that the analysis of the object area suffered during the first thirty years with the anthropic pressure, mainly by the real estate interest, either to rural or urban use, for the detriment of remaining native forest, which lost $15.775,83 \mathrm{ha}$, representing $18,80 \%$ of the protected territory. Thus the native forest patches came out from 597 fragments in 1984 to 808 in 2014, showing a disintegration of native forest blocks through a fragmentation that occurred in a gradual and timely manner, highlighting perforations, which preceded the disappearance of native forest. Concerning Public Policy, stands out the provisions of the Master Plan for Land Use Planning, 2009 (Complementary Law $803 / 2009$ ), which indicate $25.59 \%$ of the EPASBR to urbanization, endangering the maintenance $6.033,82$ ha of native forest that in 2014 were in the built-up area. On the other hand, Law no 5.344/2014 amounted to $45.86 \%$ the area of greatest environmental restrictions in this protected area, covering $72.80 \%$ of the native forest existing in 2014.
\end{abstract}

Keywords: Change detection, Fragmentation change detection, Environmental Protected Area of São Bartolomeu River. 


\section{CAPITULO 1 - APRESENTAÇÃO GERAL}

\subsection{INTRODUÇÃO}

A conversão de grandes remanescentes de florestas em fragmentos dispersos e isolados reduz a prestação de serviços ecossistêmicos. A manutenção da cobertura vegetal é de extrema importância para garantir a provisão e regulação da água, aumentando da infiltração de água no solo e reduzindo o escoamento superficial e os processos erosivos (CRIADO, 2012; CASSIANO, 2013).

A politica florestal brasileira movida por pressões internas e externas passa por atualizações, buscando maior eficiência na gestão dos recursos florestais. As obrigações assumidas pelo governo brasileiro perante a comunidade internacional levam a crer que o conhecimento e a preservação da vegetação nativa brasileira passam a ter ainda mais relevância (SCARANO et al., 2012). Essa postura tem feito crescer a demanda por informações confiáveis acerca das modificações de uso do solo, dos limites geográficos e do estado de preservação da flora dos biomas brasileiros de tal forma que o planejamento e a gestão ambiental devem prescindir de mapas atualizados que permitam fazer o controle de suas modificações (SÁNCHEZ-AZOFEIFA et al., 2003).

No intuito de mitigar o potencial poluidor das atividades humanas, assegurando a manutenção de espaços de interesse ambiental para as futuras gerações, assim como, garantir a preservação de paisagens específicas e raras, monumentos naturais, espécies da flora e fauna silvestre, entre outros, são criadas as unidades de conservação (SCHENINI et al., 2004), que atualmente através da Lei Federal 9.985/2000 dividem-se em dois grupos (Unidades de Proteção Integral e Unidades de Uso Sustentável) com doze categorias, abrangendo áreas públicas e particulares (Tabela 1).

O Sistema Nacional de Unidades de Conservação (SNUC) define e regulamenta as categorias de unidades de conservação nas instâncias federal, estadual e municipal, separando-as em dois grupos: de proteção integral, com a conservação da biodiversidade como principal objetivo, e áreas de uso sustentável, que permitem várias formas de utilização dos recursos naturais, com a proteção da biodiversidade como um objetivo secundário (RYLANDS \& BRANDON, 2005). 
Tabela 1.1: Grupos, categorias, tipo de posse e usos permitidos por lei em unidades de conservação no Brasil.

\begin{tabular}{|c|c|c|c|}
\hline Grupo & Categoria & $\begin{array}{l}\text { Tipo de } \\
\text { posse }\end{array}$ & Usos permitidos por lei \\
\hline \multirow{5}{*}{$\begin{array}{l}\text { Proteção } \\
\text { Integral }\end{array}$} & Estação Ecológica & Pública & Pesquisa científica e educação ambiental \\
\hline & Reserva Biológica & Pública & Pesquisa científica e educação ambiental \\
\hline & Parque Nacional & Pública & $\begin{array}{l}\text { Pesquisa científica, educação ambiental, } \\
\text { recreação em contato com a natureza e turismo } \\
\text { ecológico }\end{array}$ \\
\hline & Monumento Natural & $\begin{array}{l}\text { Pública e } \\
\text { particular }\end{array}$ & $\begin{array}{l}\text { Pesquisa científica, visitação pública, agropecuária } \\
\text { ou outros usos particulares, desde que } \\
\text { compatibilize os objetivos da unidade com a } \\
\text { utilização da terra e dos recursos naturais do local } \\
\text { pelos proprietários }\end{array}$ \\
\hline & $\begin{array}{l}\text { Refúgio de Vida } \\
\text { Silvestre }\end{array}$ & $\begin{array}{l}\text { Pública e } \\
\text { particular }\end{array}$ & $\begin{array}{l}\text { Pesquisa científica, visitação pública, agropecuária } \\
\text { ou outros usos particulares, desde que } \\
\text { compatibilize os objetivos da unidade com a } \\
\text { utilização da terra e dos recursos naturais do local } \\
\text { pelos proprietários }\end{array}$ \\
\hline \multirow{7}{*}{$\begin{array}{l}\text { Uso } \\
\text { Sustentável }\end{array}$} & $\begin{array}{l}\text { Área de Proteção } \\
\text { Ambiental }\end{array}$ & $\begin{array}{l}\text { Pública e } \\
\text { particular }\end{array}$ & $\begin{array}{l}\text { Ocupação humana diversificada, sendo que as } \\
\text { propriedades rurais podem ter o processo de } \\
\text { ocupação disciplinado/restringido por regulamento } \\
\text { específico }\end{array}$ \\
\hline & $\begin{array}{l}\text { Área de Relevante } \\
\text { Interesse Ecológico }\end{array}$ & $\begin{array}{l}\text { Pública e } \\
\text { particular }\end{array}$ & $\begin{array}{l}\text { Ocupação humana diversificada, sendo que as } \\
\text { propriedades rurais podem ter o processo de } \\
\text { ocupação disciplinado/restringido por regulamento } \\
\text { específico }\end{array}$ \\
\hline & Floresta Nacional & $\begin{array}{l}\text { Pública com } \\
\text { concessão } \\
\text { de uso }\end{array}$ & $\begin{array}{l}\text { Pesquisa científica, visitação pública, uso múltiplo } \\
\text { sustentável dos recursos florestais, com ênfase } \\
\text { em métodos para exploração sustentável de } \\
\text { florestas nativas }\end{array}$ \\
\hline & Reserva Extrativista & $\begin{array}{l}\text { Pública com } \\
\text { concessão } \\
\text { de uso }\end{array}$ & $\begin{array}{l}\text { Pesquisa científica, visitação pública, extrativismo, } \\
\text { agricultura de subsistência e criação de animais de } \\
\text { pequeno porte, extração comercial de madeira em } \\
\text { bases sustentáveis e em situações especiais e } \\
\text { complementares às demais atividades }\end{array}$ \\
\hline & Reserva de Fauna & Pública & $\begin{array}{l}\text { Estudos técnico-científicos sobre o manejo } \\
\text { econômico sustentável de recursos faunísticos e } \\
\text { visitação pública }\end{array}$ \\
\hline & $\begin{array}{l}\text { Reserva de } \\
\text { Desenvolvimento } \\
\text { Sustentável }\end{array}$ & $\begin{array}{l}\text { Pública e } \\
\text { particular }\end{array}$ & $\begin{array}{l}\text { Pesquisa científica voltada à conservação da } \\
\text { natureza, visitação pública, educação ambiental, } \\
\text { exploração de componentes dos ecossistemas } \\
\text { naturais em regime de manejo sustentável e } \\
\text { substituição da cobertura vegetal por espécies } \\
\text { cultiváveis, desde que sujeitas ao zoneamento }\end{array}$ \\
\hline & $\begin{array}{l}\text { Reserva Particular do } \\
\text { Patrimônio Natural }\end{array}$ & Particular & $\begin{array}{l}\text { Pesquisa científica, visitação com objetivos } \\
\text { turísticos, recreativos e educacionais }\end{array}$ \\
\hline
\end{tabular}


Reúne-se às unidades de conservação o Cadastro Ambiental Rural - CAR, criado pela Lei Federal 12.651/2012, que comprovam a inserção definitiva da geotecnologia nas politicas públicas, pretendendo reunir em um único sistema todas as informações ambientais dos imóveis rurais brasileiros. Este instrumento deseja reproduzir em dados vetoriais às nuances ambientais das unidades produtivas, tendo como bases principais as áreas de remanescentes de vegetação nativa e de uso consolidado, permitindo o desenvolvimento de estratégias que promovam a conexão de vegetação natural dos imóveis rurais explorados economicamente com as unidades de conservação.

O arcabouço legal para definição de áreas destinadas a proteção é decorrente da década de 1980, servindo de base para a criação das primeiras unidades de conservação denominadas Área de Proteção Ambiental (APA), sendo uma delas a APA do Rio São Bartolomeu, criada pelo Decreto n 88.940, de 07 de novembro de 1983, juntamente com a APA do Rio Descoberto, ambas localizadas no Distrito Federal, com o intuito de proporcionar o bem-estar futuro das populações, bem como assegurar condições ecológicas satisfatórias às represas projetadas para as regiões.

A criação de unidades de conservação se dá pela necessária proteção da biodiversidade de uma determinada região, cabendo um regime de maior ou menor restrição a depender da categoria desta unidade. A Área de Proteção Ambiental APA é uma categoria que permite a coexistência de atividades antrópicas desde que haja um regime diferenciado de proteção, desta forma a APA do Rio São Bartolomeu tem essa característica.

A proteção ambiental está diretamente relacionada a conservação e uso sustentável dos remanescentes de vegetação nativa, para a manutenção da água, preservação da fauna e flora, além da estabilidade geológica. Desta forma, é importante que se estude a eficácia da criação das unidades de conservação, com vista à análise da obediência de suas normas e respeito ao regime normativo que norteiam a gestão destas unidades.

Para viabilizar a implementação da Lei Federal 12.651/2012, auxiliando no aprimoramento da Lei Federal 9.985/2000 é necessário acessar tecnologias como o sensoriamento remoto, que é um conjunto de atividades que permite a obtenção de informações dos objetos que compõem a superfície terrestre sem a necessidade de contato direto com os mesmos. 
O CAR é trazido ao cenário ambiental dos imóveis rurais brasileiros através da Lei Federal 12.651/2012. O instrumento prevê a reunião das características ambientais de todos os imóveis rurais do Brasil, a partir de então buscar caminhos para a regularização ambiental destes imóveis. Dentre as áreas protegidas que serão definidas pelo CAR estão as Áreas de Preservação Permanente - APP e as Reservas Legais, institutos e proteção que necessitam de tecnologias geoespacializadas para a correta definição.

Um marco Lei Federal 12.651/2012 foi estabelecer um tratamento diferenciado aos imóveis rurais com áreas protegidas ocupadas até 22 de julho de 2008, data da publicação do Decreto Federal 6.514/2008, que regulamenta a Lei 9.605/1998, que discorre sobre crimes ambientais. Deste modo, faz-se necessário o conhecimento da cobertura da Terra em 2008, para deliberar sobre a definição das áreas protegidas e dimensionar os passivos a serem recuperados em cada imóvel rural. Tais informações irão subsidiar o Programa de Regularização Ambiental PRA, que conduzirá a restauração da vegetação em APPs e Reservas Legais.

Portanto, conhecer o histórico da cobertura da Terra e a dinâmica dos remanescentes de vegetação nativos é fundamental para a correta e justa implementação dos instrumentos previstos pela Lei Federal 12.651/2012. A partir de então, além de conduzir a recomposição dos passivos ambientais, será possível deliberar sobre os ativos ambientais e estabelecer estratégias para manter ou promover os corredores ecológicos através dos fragmentos existentes.

A tecnologia desenvolvida em sensoriamento remoto tem um papel importante em Ecologia de Paisagem e, por conseguinte, no monitoramento das alterações provocadas em áreas naturais, possibilitando em geral percepções mais precisas dos diferentes tipos de vegetações, o que pode possibilitar ações de interesse acadêmico, subsídios para elaboração de planos de manejo, delineamento de habitats disponíveis para fauna, identificação de remanescentes de vegetação fora de áreas legalmente protegidas ou para o planejamento ambiental em uma escala que abarque bacias hidrográficas ou outras unidades da paisagem (LIU, 2007; OLIVEIRA et al., 2009).

O estudo da componente temporal associado às informações espaciais e espectrais pode revelar os padrões e a complexidade de processos sobre a dinâmica de uso do solo e monitoramento ambiental (BRUZZONE et al., 2003; CRUSCO, 2006). O método de classificação irá variar conforme o objetivo do trabalho, qualidade e época das imagens disponíveis do local de estudo. Ainda que 
os avanços tecnológicos tenham buscado em equações matemáticas o máximo de automação possível, evitando inconsistências advindas das limitações humanas, ainda é possível optar por classificações visuais, uma vez que os materiais disponíveis e o contexto da pesquisa demonstrem viabilidade técnica para o uso desta alternativa.

Para a detecção de mudança, é necessário identificar e remover as alterações causadas por fatores externos, tais como diferenças nas condições atmosféricas, os ângulos de iluminação e visualização, e sensor de oscilação, a fim de destacar apenas as alterações espectrais de interesse (CARVALHO JÚNIOR et al., 2011).

Com os resultados de classificação, podemos obter as informações referentes a fragmentação da paisagem da área estudada, que para Cerqueira et al. (2003) é o processo no qual um habitat contínuo é dividido em manchas, ou fragmentos, mais ou menos isolados. O processo de fragmentação da paisagem por ações antrópicas torna o ecossistema frágil, interferindo no equilíbrio ecológico do ambiente atingido. Dessa forma, nos leva a um cenário preocupante, que justifica a realização de pesquisas que possam entender as alterações e sirvam de norteadoras para ações que busquem a manutenção da sustentabilidade dos fragmentos (IRGANG et al., 2007).

Dessa forma, o conhecimento da dinâmica das ações antrópicas sobre os remanescentes de vegetação nativa na APA do Rio São Bartolomeu, se faz necessário para compreendermos o legado da criação desta área protegida, vislumbrando os efeitos das ações governamentais frente a proteção dos recursos naturais e envolvimento da população local em face do manejo proposto por uma unidade de conservação, considerando a fragilidade ambiental do território.

Tal análise pode ser feita através de recursos advindos do sensoriamento remoto, por meio de técnicas de classificação da cobertura da Terra e análise da fragmentação da paisagem, permitindo a avaliação da eficiência de medidas protetivas aos remanescentes de vegetação nativa nesta unidade de conservação, no período de 30 (trinta) anos após a sua criação.

Ante o exposto, o presente trabalho teve como objetivo avaliar a mudanças espaciais e temporais na cobertura da Terra na APA do Rio São Bartolomeu. Mensurando o quantitativo de perda de vegetação natural e avaliando a fragmentação da paisagem na área de estudo após 30 anos de criação da unidade de conservação. 


\subsection{ANÁLISE DE SÉRIES TEMPORAIS E DETECÇÃO DE MUDANÇAS}

Os estudos sobre o "uso da terra" devem contemplar as variações no espaçotempo por força das mudanças de orientações que norteiam a utilização dos espaços em diferentes momentos. Isso é a dinâmica imposta pelos ciclos econômicos sobre o uso das terras impõe uma variação nestes ambientes ao longo do tempo, com consequências para o espaço físico, ou seja, áreas que em determinados períodos eram destinadas à produção podem ser, em outros períodos, abandonadas, de forma que o contrário também pode ser verdadeiro (LEITE \& BRITO, 2012).

Uma análise temporal consiste na comparação quali-quantitativa entre dois períodos de tempo de uma mesma região. Quando esta comparação se dá em mais de dois períodos é denominada de multitemporal. Consiste basicamente na extração de informações provenientes de dados de um mesmo local obtido em momentos distintos (LANGLEY et al., 2001).

O emprego de imagens orbitais constituem ferramentas indispensáveis para a detecção, avaliação e monitoramento espaço-temporal dos problemas relacionados ao meio ambiente, em virtude da integração e sobreposição de dados diferentes, em variadas escalas, permitido pelos sistemas de informação geográfica, facilitando a tomada de decisões e reorientações, quando necessárias, de políticas de uso e ocupação do solo (AQUINO et. al., 2012).

A verificação dos padrões de uso da terra ao longo do tempo auxilia o estudo de fenômenos associados à ocupação de uma determinada região. Neste contexto, a análise temporal, que consiste na extração de informações provenientes de dados de um mesmo local obtido em momentos distintos (LANGLEY et al., 2001), permite detectar as mudanças pelas variações presentes nas datas consideradas. Este tipo de análise é de imprescindível importância para monitorar áreas desflorestadas, acompanhar a ocupação de terrenos relacionada a características dos solos de determinada região ou como instrumento de monitoramento em unidades de conservação (SANTOS \& BAYMA, 2009).

Nos últimos anos, as tecnologias de análises multitemporais vêm extrapolando a academia e passando a nortear também políticas públicas de ordenamento territorial. Tais ferramentas são imprescindíveis para a constatação de tendências que podem ser interrompidas, controladas ou estimuladas pelo poder público. A desatenção às mudanças passíveis de constatação por sensoriamento 
remoto pode resultar a grande prejuízo com o passar dos tempos. A crise hídrica que assola o Brasil e vem chamando atenção aos noticiários nos últimos anos, poderia ser minimizada com tomadas de decisões que obedecessem a constatações advindas de análises multitemporais.

O custo de reverter o atual cenário é muito maior do que o dos possíveis controles em longo prazo, que poderiam ter sido adotados na observância da perda de vegetação em faixas que contornam os corpos hídricos que abastecem a população. Ainda que possa parecer uma revolução tecnológica, o estudo multitemporal sobre o território não requer de muitos investimentos, certamente muito menos dispendioso que remediar a perda de um corpo hídrico, uma erosão ou um desmoronamento que a falta de planejamento possa causar.

\subsection{CARACTERÍSTICAS DO SENSOR LANDSAT TM}

O sensor do satélite Landsat Thematic Mapper (TM) é utilizado para avaliar a manchas de desmatamento, a partir de tal informação é possível usar como referência para avaliar em diferentes metodologias (ZHU et al., 2014). Tais imagens são as mais comuns e importantes fontes de dados para a classificação e monitoramento de atributos ambientais (CARDOSO et al., 2014).

O sensor LANDSAT 5 foi lançado em 1984 e operou até novembro de 2011, enviando imagens durante vinte e nove anos e concluindo uma volta na terra a cada 99 minutos, realizando uma cobertura total da Terra em dezesseis dias. Durante esses anos o sensor auxiliou na análise dos impactos sofridos pelas paisagens devido as mudanças temporais ocorridas por ações naturais o antrópicas. O sensor TM (Thematic Mapper) a bordo do satélite LANDSAT 5 capta imagens da superfície terrestre com cenas de $185 \mathrm{Km}$ e resolução espacial de 30 metros (USGS, 2016).

Tabela 1.2: Características do Sensor TM

\begin{tabular}{|c|c|}
\hline \multicolumn{2}{|c|}{ CARACTERÍSTICAS DO SENSOR - TM (Thematic Mapper) } \\
\hline \multirow{2}{*}{ Bandas espectrais } & $\begin{array}{c}\text { Banda } 1-\text { Azul }(0,450-0,520 \mathrm{um}) \\
\text { Banda } 2-\text { Verde }(0,520-0,600 \mathrm{um}) \\
\text { Banda } 3-\text { Vermelho }(0,630-0,690 \mathrm{um})\end{array}$ \\
& $\begin{array}{c}\text { Banda } 4-\text { Infravermelho próximo }(0,760-0,900 \mathrm{um}) \\
\text { Banda } 5-\text { Infravermelho médio }(1,550-1,750 \mathrm{um}) \\
\text { Banda } 6-\text { Infravermelho termal }(10,40-12,50 \mathrm{um}) \\
\text { Banda } 7 \text { - Infravermelho médio }(2,080-2,350 \mathrm{um})\end{array}$ \\
\hline Resolução espacial & $\begin{array}{c}\text { Bandas } 1-5 \text { e } 7-30 \text { metros } \\
\text { Banda } 6-80 \text { metros }\end{array}$ \\
\hline Largura da faixa imageada & $185 \mathrm{~km}$ \\
\hline Resolução temporal & 16 dias \\
\hline
\end{tabular}

Fonte: (GONÇALVES, 2002) 
Tabela 1.3: Intervalo espectral do sensor TM

\begin{tabular}{|c|c|}
\hline Banda & Intervalo espectral $(\boldsymbol{\mu m})$ \\
\hline $\mathbf{1}$ & $(0,45-0,52)$ \\
\hline $\mathbf{2}$ & $(0,52-0,60)$ \\
\hline $\mathbf{3}$ & $(0,63-0,69)$ \\
\hline $\mathbf{4}$ & $(0,76-0,90)$ \\
\hline $\mathbf{5}$ & $(1,55-1,75)$ \\
\hline $\mathbf{6}$ & $(10,4-12,5)$ \\
\hline $\mathbf{7}$ & $(2,08-2,35)$ \\
\hline
\end{tabular}

Fonte: (GONÇALVES, 2002)

\subsection{FRAGMENTAÇÃO DA PAISAGEM}

De acordo com Korman (2003) a fragmentação da paisagem é definida como sendo a separação ou desligamentos não naturais de áreas amplas em fragmentos espacialmente segregados, promovendo a redução dos tipos de habitat e a divisão dos habitats remanescentes em unidades menores $e$ isoladas, o que afeta a biodiversidade e a qualidade ambiental.

A fragmentação de habitats é um processo comum relacionado com a alteração da paisagem e afeta tanto a sua estrutura como função (BOTEQUILHA LEITAO \& AHERN, 2002; CRUZ et al., 2013), logo, o termo fragmentação é utilizado para descrever um estado ou um processo de alteração de habitats. Enquanto o estado se refere a separação de habitats inicialmente ligados, o processo resulta duma alteração do desenho ou da disposição espacial dos habitats ao longo do tempo, e compreende três componentes espaciais: a) redução no tamanho dos habitats, b) aumento do numero de manchas e c) aumento do seu isolamento e perda de conectividade (HUNTER, 1996; CRUZ et al., 2013).

A qualidade ambiental ou integridade da paisagem pode ser avaliada pelo seu grau de fragmentação, que permite evidenciar não somente a quantidade de área desflorestada como também a estrutura da paisagem a partir de indicadores quantitativos como o tamanho, forma e a conectividade entre os remanescentes florestais (IRGANG et al., 2006).

Dentre as consequências mais importantes do processo de fragmentação da paisagem, destacam-se a diminuição da diversidade biológica, o distúrbio do regime hidrológico das bacias hidrográficas, as mudanças climáticas, a degradação dos recursos naturais e a deterioração da qualidade de vida das populações tradicionais (VIANA, 1990; MARTINS et al., 2002; BEZERRA, 2010). 
Os indicadores de fragmentação permitem compreender quão fragmentada a área de estudo se encontra e, qual a sustentabilidade dos fragmentos encontrados. Os indicadores são empregados para verificar, quais as chances dos fragmentos permanecerem na paisagem. As métricas utilizadas podem ser divididas em 3 grupos: Métricas de Borda; Métricas de Forma; Métricas de Tamanho, Variabilidade e Densidade (GUIMARÃES, 2012).

Sendo assim, o planejamento do uso da terra, considerando a distribuição espacial dos remanescentes florestais, tornou-se uma importante ferramenta para propostas que visam à minimização dos impactos causados pela fragmentação de habitat (MUCHAILH, 2007; BEZERRA, 2010).

\subsection{ESTRUTURA DA DISSERTAÇÃO}

Esta dissertação está construída em formato de artigo cientifico, opção prevista pela Resolução no 1 do Colegiado do Programa de Pós-Graduação em Geografia da Universidade de Brasília (UnB), datada de 23 de setembro de 2013. Tal alternativa tem como objetivo facilitar a preparação de trabalhos para divulgação dos produtos gerados nos cursos de Mestrado e Doutorado (Figura 1.2).

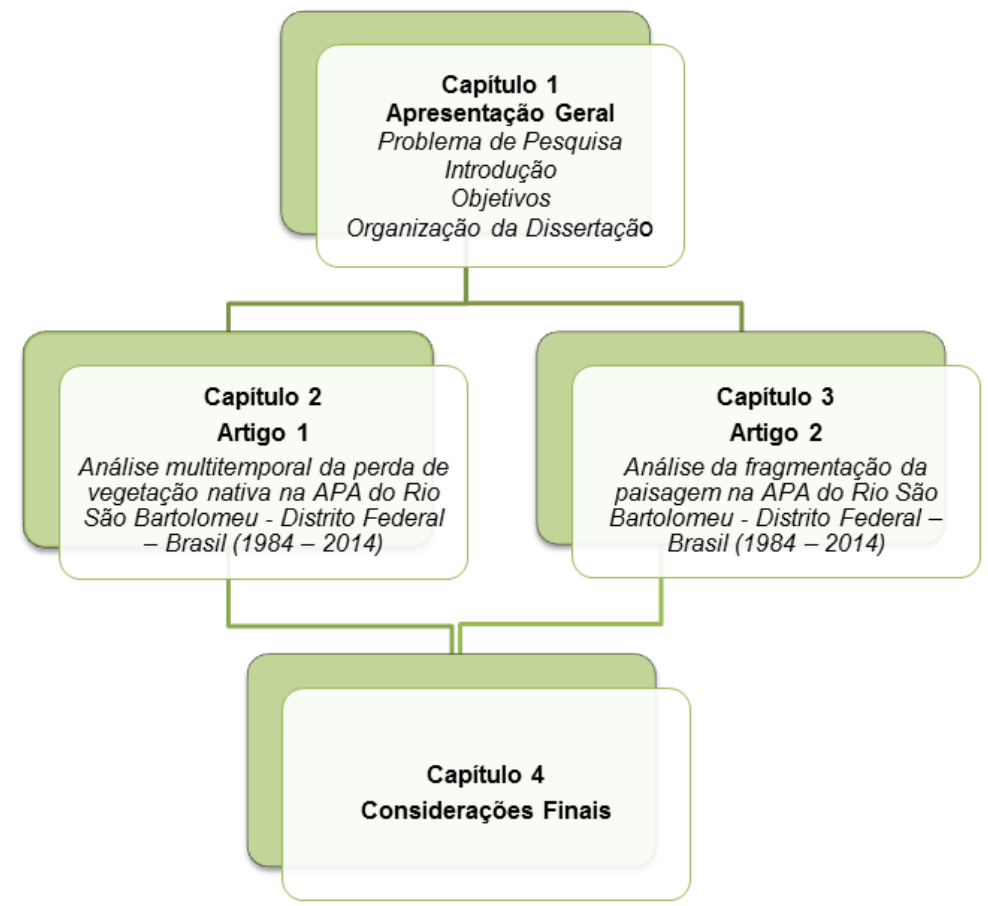

Figura 1.2: Fluxograma da Dissertação. 
O Capítulo 1 é uma introdução trazendo o arcabouço teórico que subsidiarão os próximos capítulos, neste é abordado às possibilidades e recursos tecnológicos para os estudos de análise de séries temporais, visando à detecção de mudanças e posterior fragmentação da paisagem. Destacando também imagens TM-LANDSAT disponíveis na região de estudo dos artigos científicos a serem apresentados.

O Capítulo 2 auferiu o uso e cobertura da Terra na unidade de conservação APA do Rio São Bartolomeu, no Distrito Federal, avaliando a proteção dos remanescentes de vegetação nativa. Para tal, utilizamos a fotografia aérea de alta resolução espacial $(0,23 \mathrm{~m})$, obtido por levantamento realizado pelo Governo do Distrito Federal em 2014, e série temporal do sensor Landsat 5 TM, órbita 221 ponto 71, dos anos de 1984, 1987, 1990, 1993, 1996, 1999, 2002, 2005, 2008 e 2011, sendo realizada por interpretação visual, com posterior analise de detecção de mudanças através da tabulação cruzada. $O$ estudo levou em consideração os fatores naturais e políticos que controlam as atividades antrópicas, como declividade e leis de rezoneamento da unidade de conservação.

O Capítulo 3 trouxe a análise de fragmentação da paisagem APA do Rio São Bartolomeu, utilizando dos resultados do Capítulo 2, processados através dos programas Path Analyst e V-Late para observar as métricas tradicionais, além do Guidos Toobox, estudando as mudanças nas classes da MSPA (Morphological Spatial Pattern Analysis), com foco nos remanescentes de vegetação nativa existentes na unidade entre os anos de 1984 e 2014.

Para finalizar, o Capítulo 4 apresenta uma abordagem geral e conclusões frente aos resultados obtidos nos capítulos anteriores. 


\section{REFERÊNCIAS}

AQUINO, C. M. S.; ALMEIDA, J. A. P.; OLIVEIRA, J. G. B.; Estudo da cobertura vegetal/uso da terra nos anos de 1987 e 2007 no núcleo de degradação/desertificação de São Raimundo Nonato - Piauí; Ra'e ga (UFPR), v. 25, p. 252-278, 2012.

BEZERRA, C. G.; ESTUDO DA FRAGMENTAÇÃO DA PAISAGEM E ECOLOGIA DA PAISAGEM NA SUB-BACIA DO CÓRREGO HORIZONTE, ALEGRE, ES; Dissertação de Mestrado - Universidade Federal do Espírito Santo - UFES; Jerônimo Monteiro - ES, 2010.

BOTEQUILHA, L. A.; AHERN, J.; Applying landscape ecological concepts and metrics in sustainable landscape planning; Landscape and Urban Planning, 2002.

BRASIL; Lei 9.605, de 12 de fevereiro de 1998; Lei de Crimes Ambientais.

BRASIL; Lei 9.985, de 18 de julho de 2000; Sistema Nacional de Unidades de Conservação - SNUC.

BRASIL; Lei 12.651, de 25 de maio de 2012; Lei de proteção da vegetação nativa.

BRASIL; Decreto 6.514, de 22 de julho de 2008; Regulamenta a Lei 9.605/1998.

BRUZZONE, L.; SMITS, P.C.; TILTON, J.C. FOREWORD; Special issue on analysis of multitemporal remote sensing images; IEEE Transactions on Geoscience and Remote Sensing, v.41, n.11, p. 2419-2420, 2003.

CARDOSO, G. F.; SOUZA JÚNIOR, C.; FILHO, P. W. M. S.; Using spectral analysis of Landsat-5 TM images to map coastal wetlands in the Amazon River mouth, Brazil; Wetlands Ecol Manage; 2014.

CARVALHO, O. A.; GUIMARÃES, R. F.; GILLESPIE, A. R.; SILVA, N. C. da; GOMES, R. A. T.; A New Approach to Change Vector Analysis Using Distance and Similarity Measures; Remote Sensing, v. 3, p. 2473-2493, 2011.

CASSIANO, C. C.; O papel dos remanescentes florestais na manutenção da qualidade da água em microbacias agrícolas; Universidade de São Paulo - USP; Dissertação de Mestrado; São Paulo - SP; 2013.

CRIADO, R. C.; Análise do uso da terra nas áreas de preservação permanente dos corpos da água da bacia do córrego espraiado como subsídio para pagamentos por serviços ambientais; Universidade Estadual Paulista Júlio de Mesquita Filho, UNESP; Dissertação de Mestrado; São Paulo - SP; 2012

CRUSCO, N.A; Sensoriamento remoto para análise multitemporal da dinâmica de áreas agrícolas; Dissertação de Mestrado (Mestrado em Sensoriamento Remoto) Instituto Nacional de Pesquisas Espaciais - INPE; São José dos Campos - SP. 2006.

CRUZ, C.; MADUREIRA, H.; MARQUES, J.; Análise espacial e estudo da fragmentação da Paisagem da Aboboreira; Revista de Geografia e Ordenamento 
do Território (GOT); Centro de Estudos de Geografia e Ordenamento do Território; p. 57-82, 2013.

GONÇALVES, A. L.; Descrição dos Principais Sistemas Sensores Orbitais em Operação; Universidade Federal Fluminense; 2002.

GUIMARÃES, B. P.; Análise multitemporal do uso e ocupação do solo no município de Baianópolis (BA); Dissertação de Mestrado - Universidade de Brasília - UnB; 2012.

HUNTER, M.; Fundamentals of Conservation Biology. USA: Blackwell Science; Estimativas Anuais da População Residente; Instituto Nacional de Estatística Portugal, Lisboa, 1996.

IRGANG, G. V.; SANTOS, R. R. ; MICOL, L. . ANÁLISE DA FRAGMENTAÇÃO DA PAISAGEM E MAPEAMENTO DO VALOR PARA A CONSERVAÇÃO Exemplo de Aplicação na Amazônia Mato-Grossense. 2006.

IRGANG, G.; MICOL, L.; DOS SANTOS, R;. Análise da fragmentação da paisagem e mapeamento do valor para a conservação (Exemplo de Aplicação na Amazônia Mato-Grossense). Instituto Centro de Vida; Cuiabá - MT, 2007.

KORMAN, V.; Proposta de interligação das glebas do Parque Estadual de Vassununga (Santa Rita do Passa Quatro, SP). Dissertação de Mestrado (Mestrado em Ecologia de Agrossistemas); Escola Superior de Agricultura "Luiz de Queiroz" - ESALQ; Centro de Energia Nuclear na Agricultura; Universidade de São Paulo; Piracicaba - SP; 2003.

LANGLEY, S. K.; CHESHIRE, H.M.; HUMES, K.S.; A comparison of single date and multitemporal satellite image classifications in a semi-arid grassland; Journal of Arid Environ; 2001.

LEITE, M. R. ; BRITO, J.L.S.; Sensoriamento remoto aplicado à análise temporal da relação uso da terra / temperatura e albedo de superfície na Bacia do Rio Vieira no norte de Minas Gerais; Revista Brasileira de Climatologia, v. 10, p. 98, 2012.

LIU, W. T. H.; Aplicações de sensoriamento remoto; UNIDERP, p. 535-557; Campo Grande - MS; 2007.

MARTINS. I.C.M.; Diagnóstico ambiental no contexto da paisagem de fragmentos florestais naturais "IPUCAS" no município de lagoa da confusão, Tocantins. Revista Árvore, Viçosa, v.26, n.003, p.299-309, mai/jun. 2002.

MUCHAILH, M.C. Análise da paisagem visando à formação de corredores de biodiversidade: Estudo de caso da porção superior da Bacia do Rio São Francisco Falso, Paraná. Curitiba, 2007.

OLIVEIRA, A. K. M. de; FERNANDES, V.; GARNÉS, S. J. A.; SANTOS, C. R. B. dos. Avaliação da perda da vegetação arbórea nativa na Serra da Bodoquena, Mato Grosso do Sul, por meio de sensoriamento remoto; Ra'e ga (UFPR); v. 17; p. 43-59, 2009.

RYLANDS, A. B.; BRANDON, K.; Unidades de Conservações Brasileiras; Megadiversidade; v. 1; 2005. 
SANCHEZ-AZOFEIFA, G. A., DAILY, G. C., PFAFF, A.S.P., BUSCH, C.; Integrity and isolation of Costa Rica's national parks and biological reserves: examining the dynamics of land-cover change; Biol. Conserv; 2003.

SANTOS, R. P.; BAYMA, A. P.; Sensoriamento Remoto Aplicado à Análise Temporal da Reserva Ecológica do IBGE; Anais XIV Simpósio Brasileiro de Sensoriamento Remoto; INPE; p. 6173-6180; Natal - RN; 2009.

SCARANO, F.R.; SILVA, J.M.C.; Guimarães, A.L.; RAIK, D.; BOLTZ, F. Brazil on the spot: Rio +20 , sustainability and a role for science. Brazilian Journal Botany, v.35, n.2, p. 233-239, 2012.

SCHENINI, P. C.; COSTA, A. M.; CASARIN, V. W.; Unidades de Conservação: aspectos históricos e sua evolução. In: $6^{\circ}$ Congresso Brasileiro de Cadastro Técnico Multifinalitário; $4^{\circ}$ Encontro de Cadastro Técnico Multifinalitário para Países do MERCOSUL; $1^{\circ}$ Encontro de Cadastro Técnico Multifinalitário para Países da América Latina, 2004, Florianópolis. Anais do COBRAC 2004, 2004.

USGS - Science for a changing world; Landsat Mission; Disponível em: <http://landsat.usgs.gov/> Acesso em: 08 abril 2016.

VIANA, V. M.; Biologia e manejo de fragmentos florestais; Anais do Congresso Florestal Brasileiro; Sociedade Brasileira de Silvicultura/Sociedade de Engenheiros Florestais; Campos do Jordão - SP; 1990.

ZHU, S.; Zhang, H.; LIU, R.; CAO, Y.; ZHANG, G.; Comparison of Sampling Designs for Estimating Deforestation from Landsat TM and MODIS Imagery: A Case Study in Mato Grosso, Brazil; Hindawi Publishing Corporation -The Scientific World Journal; 2014. 


\section{CAPÍTULO 2 - ANÁLISE MULTITEMPORAL DA PERDA DE VEGETAÇÃO NATIVA NA APA DO RIO SÃO BARTOLOMEU - DISTRITO FEDERAL - BRASIL (1984 - 2014)}

\section{RESUMO}

O objetivo deste trabalho foi mensurar o quantitativo de perda da vegetação nativa na APA do Rio São Bartolomeu e acompanhar a sua dinâmica usando técnicas de sensoriamento remoto, desde a criação da unidade de conservação até a atual década. A APA do São Bartolomeu, categorizada como de uso sustentável, tem área de 82.679,88ha, em interseção com as Bacias Hidrográficas do São Bartolomeu e Preto no Distrito Federal - DF, possuindo usos urbano e rural. A detecção de mudanças utilizou a fotografia aérea de alta resolução espacial $(0,23 \mathrm{~m})$, obtido por levantamento realizado pelo Governo do Distrito Federal em 2014, e série temporal do sensor Landsat 5 TM, órbita 221 ponto 71, dos anos de 1984, 1987, 1990, 1993, 1996, 1999, 2002, 2005, 2008 e 2011, sendo realizada por interpretação visual, com posterior análise de detecção de mudanças através da tabulação cruzada. O estudo concluiu que esta unidade de conservação sofreu durante os primeiros trinta anos de existência com a pressão antrópica, principalmente pelo interesse imobiliário, seja para uso rural ou urbano, em detrimento aos remanescentes de vegetação nativa, que perderam 15.775,83ha, que representam $18,80 \%$ do território desta área protegida. Referente à política pública, destaca-se o previsto no PDOT-2009 (Lei

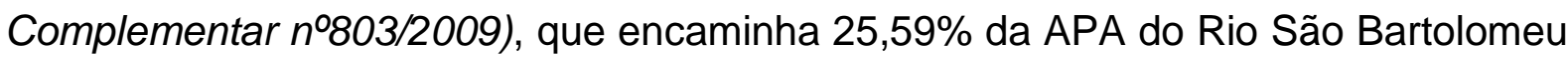
a urbanização, colocando em risco a manutenção de 6.033,82ha que em 2014 estavam na área urbanizável, por outro lado, a Lei ํ⒌344/2014, elevou para $45,86 \%$ a área de maior restrição ambiental nesta unidade de conservação, abrigando 72,80\% da vegetação natural existente em 2014.

Palavras Chaves: Detecção de mudanças, Remanescentes de vegetação nativa, APA do Rio São Bartolomeu. 


\title{
MULTITEMPORAL ANALYSIS OF THE NATIVE FOREST LOSS IN ENVIRONMENTAL PROTECTED AREA OF SÃO BARTOLOMEU RIVER - FEDERAL DISTRICT - BRAZIL (1984 - 2014)
}

\begin{abstract}
The objective of this study was to measure the quantitative loss of native forest in the Environmental Protected Area of the São Bartolomeu River - EPASBR and monitor the its dynamic using remote sensing techniques, from the creation of the protected area to the current decade. The EPASBR, categorized as sustainable use, has an area of $82.679,88$ ha, intersecting with the Watersheds of São Bartolomeu and Preto rivers in the Federal District - DF, Brazil, having urban and rural uses. The change detection used a high spatial resolution aerial photography $(0.23 \mathrm{~m})$, obtained by a survey conducted by the Government of the FD, in 2014, and time series of Landsat 5 TM sensor, orbit 221 point 71, the years 1984, 1987, 1990, 1993, 1996, 1999, 2002, 2005, 2008 and 2011, being held by visual interpretation, with subsequent change detection analysis by cross tabulation. The study concluded that the analysis of the object area suffered during the first thirty years with the anthropic pressure, mainly by the real estate interest, either to rural or urban use, for the detriment of remaining native forest, which lost $15.775,83 \mathrm{ha}$, representing $18,80 \%$ of the territory. Concerning Public Policy, stands out the provisions of the Master Plan for Land Use Planning, 2009 (Complementary Law 803/2009), which indicate 25.59\% of the EPASBR to urbanization, endangering the maintenance $6.033,82$ ha of native forest that in 2014 were in the built-up area. On the other hand, Law no 5.344/2014 amounted to $45.86 \%$ the area of greatest environmental restrictions in this protected area, covering $72.80 \%$ of the native forest existing in 2014 .
\end{abstract}

Keywords: Detection of changes, Remnants of native vegetation, Environmental Protected Area of the São Bartolomeu River. 


\subsection{INTRODUÇÃO}

A vasta cobertura vegetal promove uma série de serviços ambientais, como manutenção da biodiversidade, polinização, controle de pestes, manutenção do solo, redução da erosão, ciclagem de nutrientes, sequestro carbono, manutenção do regime de chuvas e do fluxo hidrológico, dentre outros (FILHO, 2013). Portanto, as unidades de conservação foram criadas no intuito de mitigar o potencial poluidor das atividades humanas e garantir a preservação de paisagens específicas, monumentos naturais e espécies de flora e fauna silvestre.

O período entre 1970 a 1974 foi importante para o surgimento das unidades de conservação no Brasil, com a criação da primeira reserva biológica, Poço das Antas, e o início da criação das unidades de conservação na Região Norte, contendo extensas áreas (SCHENINI et al., 2004). Na década de 1980, uma das primeiras normas que trataram do assunto foi Lei 6.902, de 27 de abril de 1981, que dispôs sobre a criação de Estações Ecológicas, Áreas de Proteção Ambiental, seguida pela a Lei oㅜ 6.938, de 31 de agosto de 1981, que implantou o Sistema Nacional de Meio Ambiente (SISNAMA). Estas serviram de base para a criação das primeiras unidades de conservação denominadas Área de Proteção Ambiental (APA), que possuíam como intuito proporcionar o bem-estar futuro das populações, bem como assegurar as condições ecológicas satisfatórias às represas projetadas.

No Distrito Federal (DF), uma importante área ambiental é a APA do Rio São Bartolomeu, criada pelo Decreto o 88.940, de 07 de novembro de 1983, juntamente com a APA do Rio Descoberto. A APA do Rio São Bartolomeu é categorizada como de uso sustentável e possui uma área de $82.679,88 \mathrm{ha}$, interceptando as Bacias Hidrográficas do São Bartolomeu e Preto e seis Regiões Administrativas do DF (Sobradinho, Planaltina, Paranoá, Santa Maria, São Sebastião e Lago Norte). O rio São Bartolomeu é o maior do DF e desde os primeiros documentos de planejamento urbano da capital federal na década de 1970 foi identificado como a fonte de água potável mais apropriada para abastecer a população, que crescia com alta taxa nesse período. Portanto, os primeiros planos diretores do DF não recomendavam a expansão urbana nesta bacia hidrográfica (FREITAS, 2009).

A unidade de conservação de uso sustentável permite a ocupação humana, conforme Lei 9.985 de 18 de julho de 2000 (Sistema Nacional de Unidades de Conservação da Natureza), porém exige-se a adoção de medidas que tenham por objetivo proporcionar o bem-estar futuro das populações. Contudo, o crescimento populacional desordenado no entorno aliado à ausência de políticas públicas 
eficientes colaboram com o desrespeito das previsões legais. Os reais efeitos da criação da APA do Rio São Bartolomeu e a sua capacidade de frear as perdas ambientais ainda não foram aferidos. A APA possui usos urbanos e rurais, principalmente de culturas de ciclo curto, tais como a soja (Glycine max), milho (Zea mays) e sorgo (Sorghum bicolor).

O objetivo deste trabalho é mensurar o quantitativo de remanescente de vegetação nativa na APA do Rio São Bartolomeu e acompanhar a sua dinâmica desde a sua criação até a atual década usando técnicas de sensoriamento remoto. A Lei Distrital no 3.031, de 18 de julho de 2002 (Politica Florestal do Distrito Federal), estabelece que pelo menos 50\% (cinquenta por cento) do território do DF tenha cobertura silvestre, assim, o estudo também contribuirá para constatar se a citada lei é obedecida na APA do Rio São Bartolomeu.

\section{2 ÁREA DE ESTUDO}

A área de estudo é a APA do Rio São Bartolomeu, localizado no DF, conforme Figura 2.1:
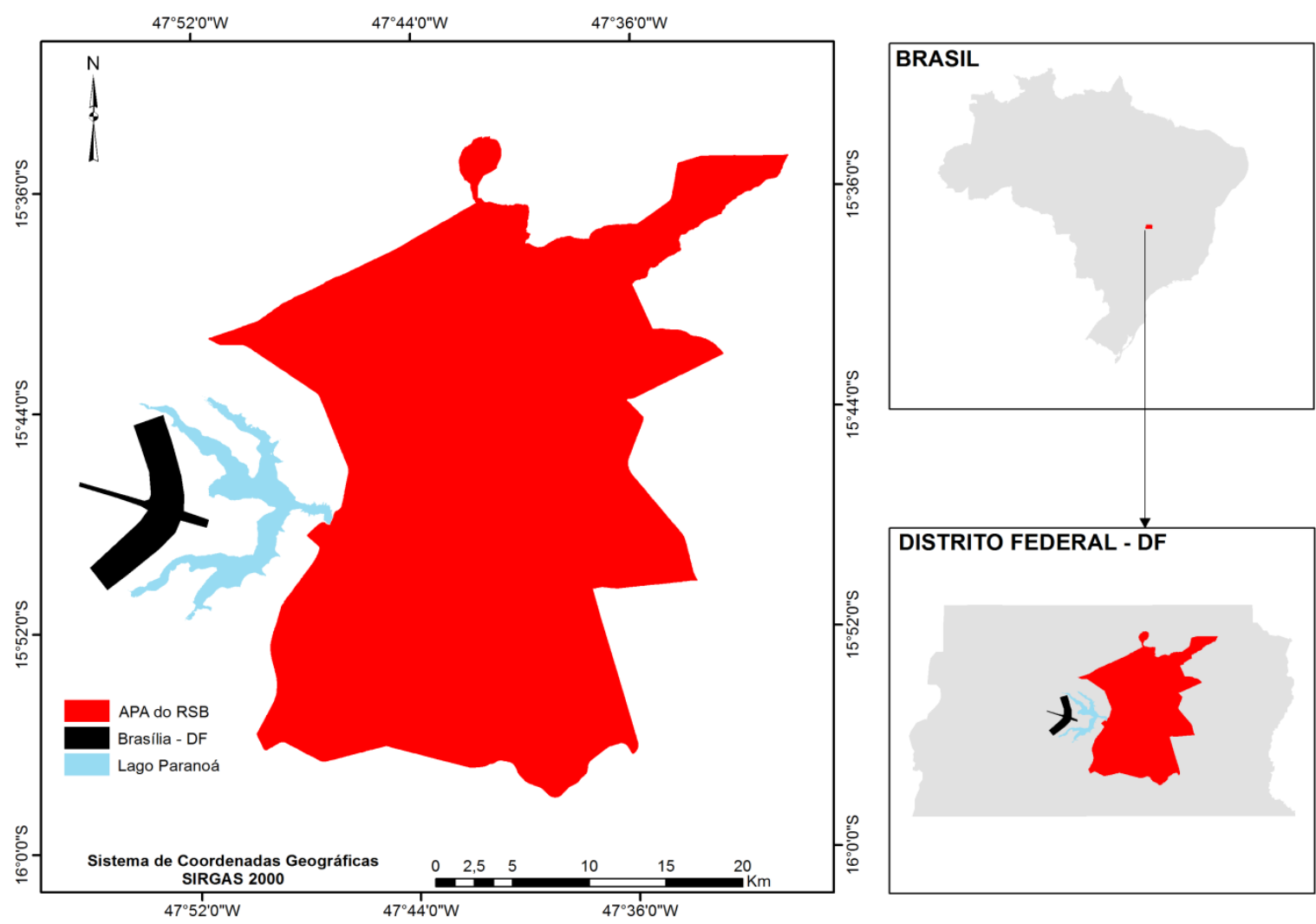

Figura 2.1 - Mapa de localização da Área de Proteção Ambiental do Rio São Bartolomeu. 
O clima da região é caracterizado por dois períodos bem demarcados: invernos secos e verões chuvosos (CARDOSO et al., 2013). O DF está localizado no Planalto Central do Brasil, onde se localizam as cabeceiras de afluentes dos três maiores rios brasileiros: Tocantins, São Francisco e Paraná. O rio São Bartolomeu pertence à bacia hidrográfica do Paraná.

A cobertura vegetal é composta por espécies do Bioma Cerrado, segundo maior bioma brasileiro contendo $21 \%$ do território nacional e superado apenas pela Amazônia (BORLAUG, 2002). No entanto, o bioma é um dos mais ameaçados no país, principalmente por conta da pressão do agronegócio e expansão urbana desordenada. $\mathrm{Na}$ área de estudo, é possível identificar principalmente as seguintes fitofisionomias do Bioma Cerrado (EITEN, 1993): Campo Limpo, Campo Sujo, Cerrado, Cerradão, Mata de Galeria e Vereda.

\subsection{MATERIAIS E MÉTODOS}

A metodologia proposta possui as seguintes etapas: (a) aquisição das imagens de Aerofotos e TM-Landsat 5 do DF; (b) classificação do uso e cobertura da Terra por interpretação visual; (c) detecção de mudança usando o método de pósclassificação; e (d) análise dos fatores que controlam as atividades antrópicas (declividade, planejamento urbano e infraestrutura).

\subsubsection{Imagens de Aerofotos e Landsat 5 TM do Distrito Federal}

O presente estudo utilizou os seguintes dados: (a) fotografia aérea de alta resolução espacial $(0,23 \mathrm{~m})$, obtido por levantamento realizado pelo Governo do DF em 2014, e (b) série temporal do sensor TM-Landsat 5 (órbita 221 ponto 71) relativo aos anos 1984, 1987, 1990, 1993, 1996, 1999, 2002, 2005, 2008 e 2011 (intervalo de três anos).

O Mapeamento Aerofotogramétrico do DF e seu entorno no ano de 2014 possui uma cobertura aproximada de $8.000 \mathrm{~km}^{2}$, utilizando câmeras fotogramétricas digitais, com resolução espacial mínima de $30 \mathrm{~cm}$. Estes produtos possuem um padrão de exatidão cartográfico "classe A", compatíveis a escala topográfica de 1:5.000 e referenciados ao sistema geodésico SIRGAS 2000 (TERRACAP, 2012).

A série temporal do sensor TM-Landsat 5 possui um intervalo de vinte e sete anos, com aquisição de imagens a cada quatro anos dentro do período 1984-2011, permitindo avaliar a dinâmica da cobertura da Terra durante os primeiros trinta anos 
após a criação da APA do Rio São Bartolomeu. A seleção das imagens do sensor TM-Landsat 5 considerou condições de baixa interferência de nuvens (Tabela 2.1).

Tabela 2.1: Imagens Landsat 5 TM utilizadas.

\begin{tabular}{|cccc}
\hline Ano & Ponto & Órbita & Data \\
\hline 1984 & 221 & 071 & $11 / 06 / 1984$ \\
1987 & 221 & 071 & $06 / 07 / 1987$ \\
1990 & 221 & 071 & $30 / 07 / 1990$ \\
\hline 1993 & 221 & 071 & $02 / 07 / 1993$ \\
\hline 1996 & 221 & 071 & $14 / 06 / 1996$ \\
\hline 1999 & 221 & 071 & $23 / 07 / 1999$ \\
\hline 2002 & 221 & 071 & $09 / 03 / 2002$ \\
\hline 2005 & 221 & 071 & $23 / 07 / 2005$ \\
\hline 2008 & 221 & 071 & $31 / 07 / 2008$ \\
\hline 2011 & 221 & 071 & $08 / 07 / 2011$ \\
\hline
\end{tabular}

Fonte: (INPE, 2015)

\subsubsection{Classificação do uso e cobertura da Terra por interpretação visual}

A classificação do uso e cobertura da terra foi realizada manualmente por interpretação visual em tela na escala 1:10.000, considerando as propriedades básicas da imagem de satélite, tais como: cor, textura, forma, estrutura e relações de contexto (FLORENZANO, 2008). A interpretação visual foi feita inicialmente nas fotografias aéreas de 2014. A partir da classificação da imagem de mais alta resolução espacial realizou-se a retroanálise para os anos anteriores, considerando uma série temporal de imagens TM-Landsat (MENKE et al., 2009; BARBOSA \& CAMPOS, 2011; FLORES et al., 2012). A classificação a partir das imagens mais recentes permitiu uma maior acurácia na sobreposição dos dados ao longo dos anos evitando pequenos deslocamentos. $\mathrm{Na}$ retroanálise, os vetores das classes invariantes são reaproveitados, havendo uma perfeita sobreposição dos dados ao longo do tempo (OLIVEIRA et al., 2014). A escolha pela interpretação visual ao invés de métodos automatizados foi devido às variações existentes nos valores de refletância das imagens, mas que não representam uma mudança de classe. Como exemplo, uma área de cultivo pode apresentar diferentes estágios da cultura que são retratados na imagem com diferentes espectros, desde o preparo para a plantação, contendo solo exposto, até a cobertura pela área plantada (FLORES et al., 2012). 
O mapeamento de uso e cobertura da Terra adotou as seguintes classes: Vegetação Nativa, Agrossilvipastoril (agricultura, pecuária e silvicultura), Urbano (cidades e adensamento urbano), Áreas Alteradas (espaços indefinidos e solo exposto), Água (cursos d'águas perenes e intermitentes, represas e reservatórios) e Estradas (vias asfaltadas).

\subsubsection{Detecção de mudanças pelo método de pós-classificação}

Os métodos de detecção de mudança baseados em sensoriamento remoto possuem como objetivo salientar as alterações na superfície terrestre, usando imagens de diferentes datas (SINGH, 1989). As mudanças naturais e antrópicos produzem variações na resposta espectral do alvo ou do fenômeno estudado permitindo a detecção por sensoriamento remoto. No entanto, os resultados das detecções podem sofrer interferências do sistema sensor (resolução espacial, radiométrica e temporal) e do meio ambiente (interferências atmosféricas, nuvens e sombras, variação na irradiância e ângulo solar, variações na fenologia vegetal e nos componentes do solo segundo as mudanças estacionais) (SINGH, 1989; ANDERSON, 2005).

No presente trabalho a pós-classificação foi escolhida para ser utilizada como método de detecção de mudança, com uma classificação individual e prévia das imagens, para posteriores comparações e quantificações das classes estudadas em cada ano (HOWARTH \& WICKWARE, 1981; MAS, 1999; MUNYATI, 2000; DE BRUIN, 2000; MENKE et al., 2009). A comparação das imagens bi-temporais é realizada por tabulação cruzada, permitindo identificar as áreas onde ocorreram as mudanças (HOWARTH \& WICKWARE, 1981; OLIVEIRA et al., 2014). Segundo Menke et al. (2009), essa técnica é de fácil atualização, compensa as variações provenientes das condições atmosféricas, mudanças fenológicas e umidade de solo e permite integrar imagens de sensores com diferentes resoluções espaciais, espectrais, temporais e radiométricas. 


\subsubsection{Fatores que controlam as atividades antrópicas}

A distribuição das atividades humanas é norteada por fatores naturais e políticos. Os fatores naturais são aqueles que determinam a vocação dos espaços, como a declividade e a pedologia. No entanto, a ocupação do solo não é apenas direcionada pelos fatores naturais, dependendo da anuência de instrumentos políticos, que são as normativas que orientam o uso e ocupação da Terra.

A APA do Rio São Bartolomeu é uma unidade de conservação, onde as atividades antrópicas devem seguir regras específicas estabelecida em seu rezoneamento. Neste sentido, a Lei Distrital no 1.149 de 11 de julho de 1996 foi o primeiro rezoneamento ambiental desta unidade de conservação, sendo substituído posteriormente pela Lei Distrital no 5.344 de 19 de maio de 2014. Paralelo às normas especificas da área protegida, destaca-se também a Lei Complementar nํ 803, de 25 de abril de 2009, que revisa do Plano Diretor de Ordenamento Territorial do Distrito Federal (PDOT). Tal norma subdivide o DF em três zonas: Macrozona Urbana, que é destinada predominantemente a atividades urbanas, Macrozona Rural, que deve recepcionar a atividades agrícolas e a Macrozona de Proteção Integral, direcionada à preservação da natureza, sendo admitido apenas o uso indireto dos recursos naturais.

No presente estudo foram avaliadas as consequências dos rezoneamentos da unidade de conservação e do PDOT na distribuição espacial e temporal do uso e cobertura da terra. Neste propósito, foram utilizadas as bases cartográficas descritas pelos rezoneamentos da APA e do PDOT. Além disso, foi gerado o mapa de declividade da área de estudo a partir da base de elevação da carta do Sistema Cartográfico do Distrito Federal - SICAD para avaliar esse fator natural como inibidor do uso urbano e agrícola.

\subsection{RESULTADOS}

\subsubsection{Resultados da evolução temporal do uso e cobertura da Terra}

A APA do Rio São Bartolomeu demonstrou uma diversidade do uso e cobertura da terra no ano de 2014. A agricultura predomina na região leste, enquanto nas regiões centrais e no oeste ocorreu um fracionamento do solo com aumento da classe de vegetação alterada, que em muitos casos precede a urbanização (Figura 2.2). 
Em 1984 a vegetação natural era predominante e as classes de uso antrópico ocupavam áreas menores que $50 \%$ da APA. No entanto, as áreas naturais vêm gradativamente diminuindo com 0 avanço das atividades agrossilvipastoris e das áreas de vegetação alterada que passam a adquirir porcentagens similares à cobertura natural (Tabela 2.2). No ano de 1984, as atividades agrossilvipastoris (21.996,20ha) possuíam distribuição aleatória na APA, sem obedecer a uma tendência de localização, diferentemente em 2014, observa-se uma concentração dos 21.359,85ha na porção leste (Figura 2.2).

As áreas antrópicas cresceram 58,84\% durante o período estudado (Figura 2.3). Os principais fatores de mudança foram os parcelamentos do solo em áreas rurais no entorno de regiões nobres de Brasília (DF), constituídos por imóveis rurais com média de 2,00ha e destinados para áreas de moradias e lazer (Figura 2.4). As áreas alteradas tendem a preceder o uso urbano, crescendo dez vezes entre os anos de 1984 (557,24 ha) e 2014 (5.407,79 ha) (Tabela 2.2). Segundo Paviani (2003), os espaços ociosos tornam-se motivo para cobiça dos especuladores imobiliários.

Outro importante indicador da antropização é o crescimento significativo da quantidade de reservatórios d'água, que visa à garantia de abastecimento de alguns imóveis rurais e a irrigação de algumas culturas. Assim, a classe de corpos d'água (cursos d'água, construção de barramentos e reservatórios artificiais) teve um crescimento em área de $0,17 \%$ na APA. Contudo, o número de reservatórios cresceu significativamente de 44 pontos d'água em 1984 para 448 em 2014 (Figura 2.5). Esse aumento ocorreu sem planejamento, desconsiderando a capacidade hídrica da região e os riscos de escassez, principalmente, para as populações localizadas a jusante dos cursos d'água.

Conforme Silva \& Neto (2007) a Bacia do Rio São Bartolomeu sofre com a ocupação desordenada tanto no DF quanto no Entorno, influenciando diretamente na qualidade e na quantidade da água, devido ao processo de ocupação por chácaras e a substituição das zonas rurais por loteamentos com características urbanas. 

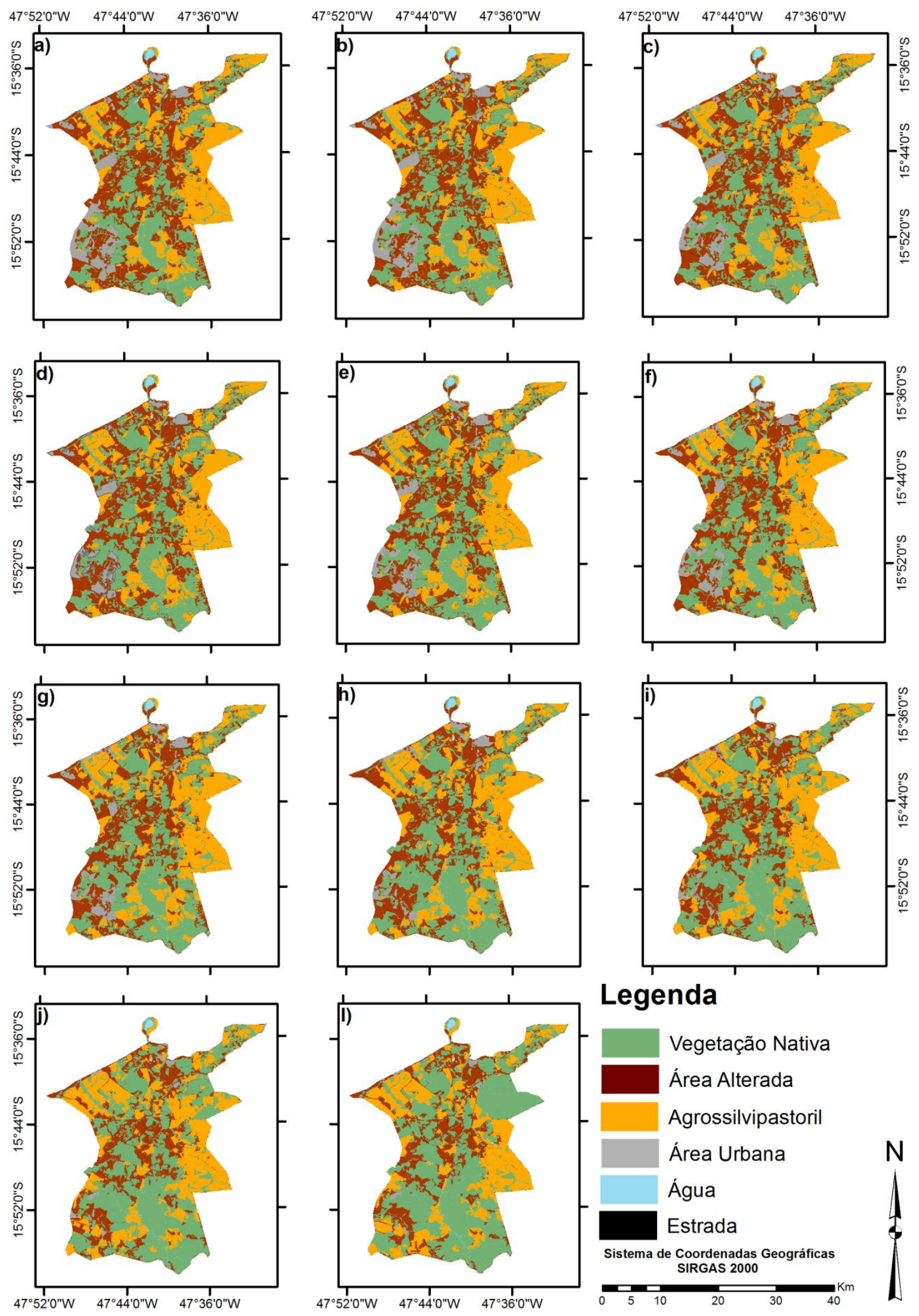

Figura 2.2 - Cobertura do solo da APA do Rio São Bartolomeu 2014 (a), 2011 (b), 2008 (c), 2005 (d), 2002 (e), 1999 (f), 1996 (g), 1993 (h), 1990 (i), 1987 (j) e 1984 (l). 
Tabela 2.2: Evolução temporal do uso e cobertura da terra na Área de Proteção Ambiental do Rio São Bartolomeu (hectares e porcentagem), considerando as seguintes classes: vegetação natural (VN), agrossilvipastoril ( $\mathrm{AgP})$, área alterada ( $\mathrm{AA})$, área urbana (AUrb) e água.

\begin{tabular}{ccccccc}
\hline Ano & & VN & AgP & AA & AUrb & Água \\
\hline \multirow{2}{*}{2014} & $h a$ & $28.132,77$ & $21.359,85$ & $27.737,38$ & $5.407,79$ & $1.040,58$ \\
& $\%$ & $(33,53)$ & $(25,46)$ & $(33,06)$ & $(6,45)$ & $(1,24)$ \\
\hline \multirow{2}{*}{2011} & $h a$ & $29.319,40$ & $21.369,70$ & $26.717,80$ & $5.363,48$ & $1.000,43$ \\
& $\%$ & $(34,94)$ & $(25,47)$ & $(31,84)$ & $(6,39)$ & $(1,19)$ \\
\hline \multirow{2}{*}{$\mathbf{2 0 0 8}$} & $h a$ & $29.936,70$ & $21.580,50$ & $26.718,30$ & $4.449,48$ & 995,56 \\
& $\%$ & $(35,68)$ & $(25,72)$ & $(31,84)$ & $(5,30)$ & $(1,19)$ \\
\hline \multirow{2}{*}{$\mathbf{2 0 0 5}$} & $h a$ & $30.529,30$ & $22.028,40$ & $25.755,80$ & $4.383,13$ & 986,16 \\
& $\%$ & $(36,39)$ & $(26,25)$ & $(30,70)$ & $(5,22)$ & $(1,18)$ \\
\hline \multirow{2}{*}{$\mathbf{2 0 0 2}$} & $h a$ & $31.027,50$ & $22.329,70$ & $25.124,30$ & $4.220,04$ & 983,38 \\
& $\%$ & $(36,98)$ & $(26,61)$ & $(29,94)$ & $(5,03)$ & $(1,17)$ \\
\hline \multirow{2}{*}{1999} & $h a$ & $31.115,40$ & $23.022,40$ & $24.547,90$ & $4.027,65$ & 974,53 \\
& $\%$ & $(37,09)$ & $(27,44)$ & $(29,26)$ & $(4,80)$ & $(1,16)$ \\
\hline \multirow{2}{*}{1996} & $h a$ & $32.381,40$ & $24.168,00$ & $22.761,90$ & $3.442,88$ & 931,34 \\
& $\%$ & $(38,59)$ & $(28,80)$ & $(27,13)$ & $(4,10)$ & $(1,11)$ \\
\hline \multirow{2}{*}{1993} & $h a$ & $34.007,30$ & $23.808,40$ & $22.758,10$ & $2.189,95$ & 921,91 \\
& $\%$ & $(40,53)$ & $(28,38)$ & $(27,12)$ & $(2,61)$ & $(1,10)$ \\
\hline \multirow{2}{*}{1990} & $h a$ & $35.937,80$ & $24.822,50$ & $20.759,80$ & $1.256,50$ & 910,12 \\
& $\%$ & $(42,83)$ & $(29,59)$ & $(24,74)$ & $(1,50)$ & $(1,08)$ \\
\hline \multirow{2}{*}{1987} & $h a$ & $39.274,70$ & $24.324,60$ & $18.371,00$ & 801,73 & 907,17 \\
& $\%$ & $(46,81)$ & $(28,99)$ & $(21,90)$ & $(0,96)$ & $(1,08)$ \\
\hline \multirow{2}{*}{$\mathbf{1} 984$} & $h a$ & $43.908,60$ & $21.996,20$ & $16.320,80$ & 557,24 & 899,83 \\
& $\%$ & $(52,33)$ & $(26,22)$ & $(19,45)$ & $(0,66)$ & $(1,07)$ \\
\hline
\end{tabular}

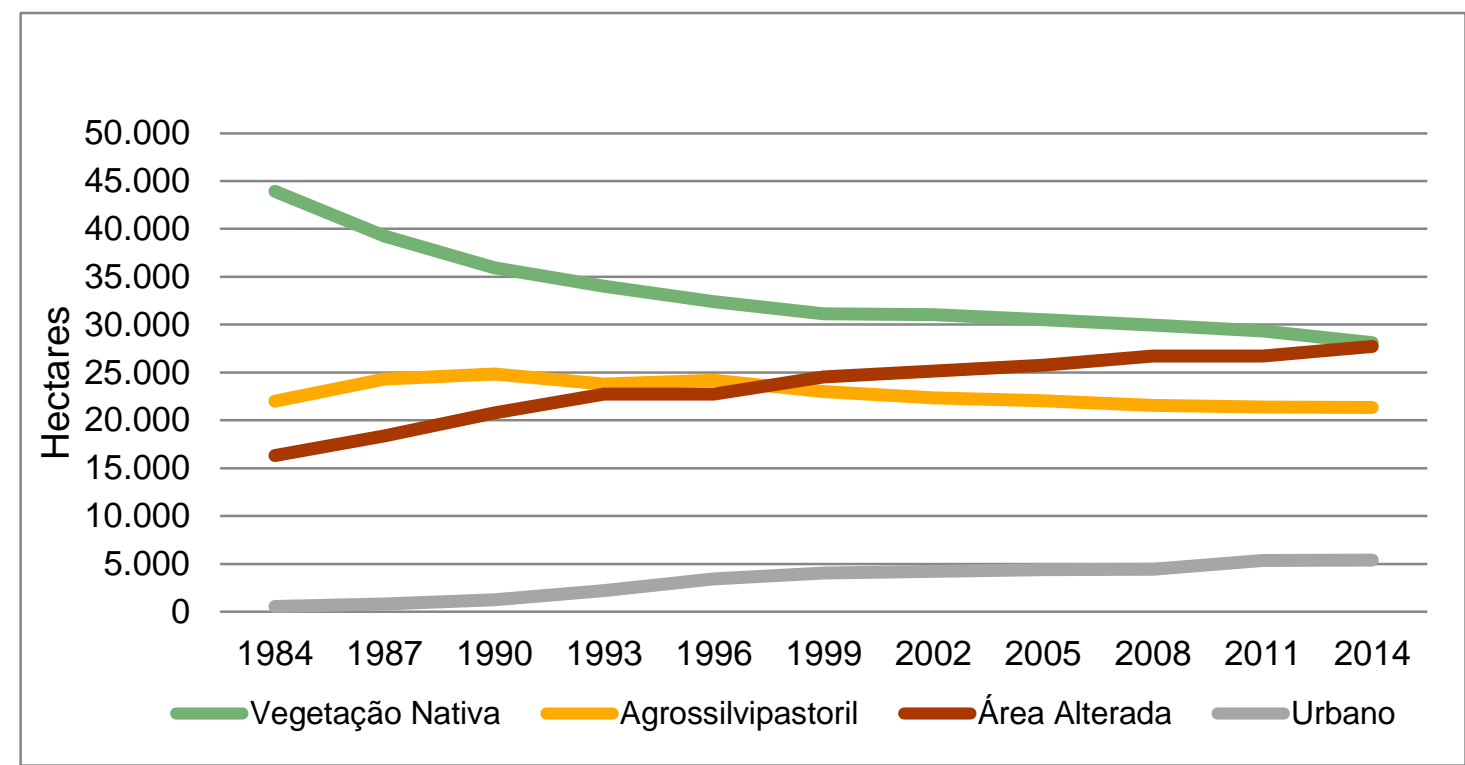

Figura 2.3 - Dinâmica do Uso e Cobertura da Terra na APA do Rio São Bartolomeu entre 1984 a 2014. 


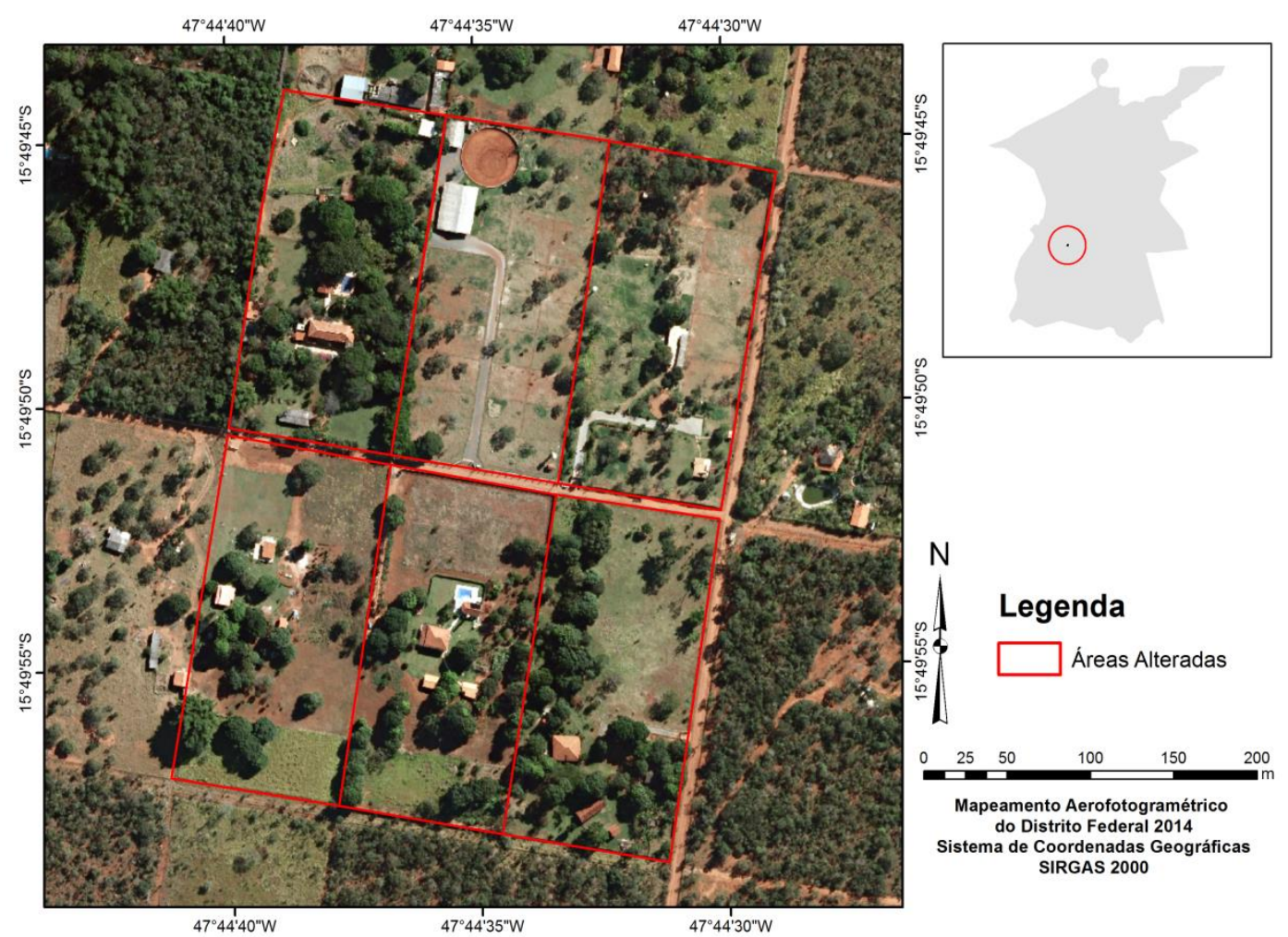

Figura 2.4 - Áreas Alteradas na APA do Rio São Bartolomeu.

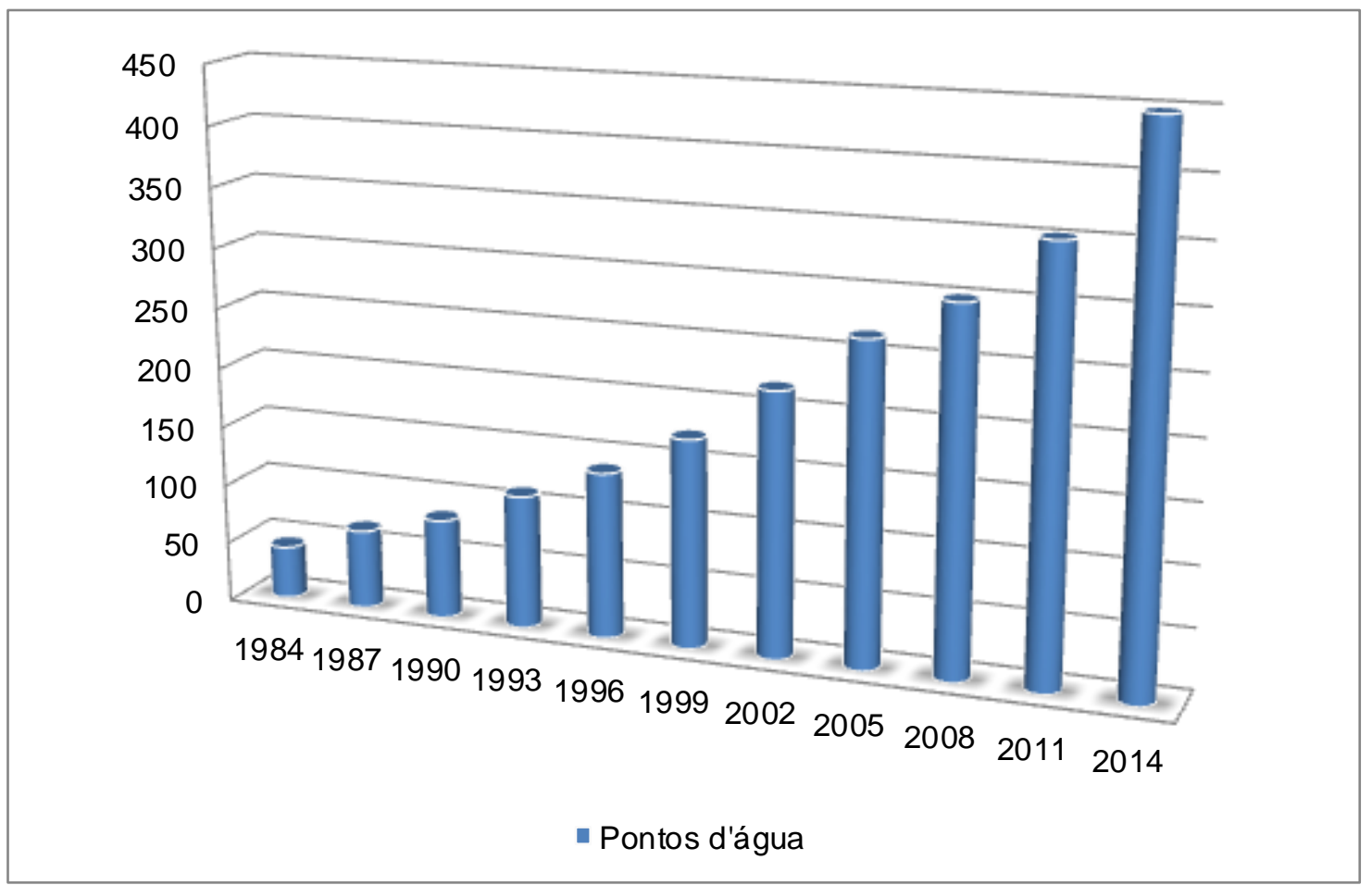

Figura 2.5 - Escalada reservatórios artificiais na APA do Rio São Bartolomeu. 


\subsubsection{Resultados da detecção de mudanças}

Os remanescentes de vegetação nativa em 1984 ocupavam 43.908,60ha (52,33\%) da APA do Rio São Bartolomeu e após 30 anos foram reduzidos para $28.132,77$ ha $(33,53 \%)$ do território (Figuras 2.6 e 2.7). A área perdida de vegetação natural foi $15.775,83$ ha, registrando um decréscimo de $35,92 \%$ quando relacionamos o que existia em 2014 em relação ao ano de 1984, conferido por um avanço continuo da ação antrópica no período estudado, conforme descrito pela Tabela 2.3:

Tabela 2.3: Divisão temporal da perda total de remanescentes de vegetação nativa durante o período estudado:

\begin{tabular}{ccc} 
Período & Hectares & $\%$ \\
\hline $1984-1987$ & $4.633,90$ & 29,37 \\
$1987-1990$ & $3.336,90$ & 21,15 \\
$1990-1993$ & $1.930,50$ & 12,24 \\
$1993-1996$ & $1.625,90$ & 10,31 \\
$1996-1999$ & $1.266,00$ & 8,02 \\
$1999-2002$ & 87,90 & 0,56 \\
$2002-2005$ & 498,20 & 3,16 \\
$2005-2008$ & 592,60 & 3,76 \\
$2008-2011$ & 617,30 & 3,91 \\
$2011-2014$ & $1.186,63$ & 7,52 \\
\hline TOTAL & $\mathbf{1 5 . 7 7 5 , 8 3 h a}$ & $\mathbf{1 0 0 \%}$
\end{tabular}

A maior pressão sobre a vegetação natural ocorreu nos primeiros anos após a criação da unidade de conservação, acompanhado por um período de estabilidade com tendência de queda chegando a 0,56\% (1999-2002). No entanto, a partir de 2002 a intensidade da pressão sobre os remanescentes de vegetação nativa volta a aumentar, avançando em 7,52\% (2011-2014).

As atividades agrossilvipastoris apresentaram pequenas oscilações no período estudado, numa variação de 636,35ha a menos entre 1984 a 2014. Neste intervalo, a agricultura deu espaço à urbanização e a áreas alteradas. A classe de vegetação alterada teve o maior avanço, crescendo 11.416,58 ha durante o período.

Ainda em 2014, a classe predominante é a de vegetação nativa, contudo, a área alterada ocupa uma área muito próxima. Dessa forma, seguindo a tendência, em poucos anos o espaço alterado estarão mais presentes que a vegetação nativa na APA do Rio São Bartolomeu (Figura 2.7). 


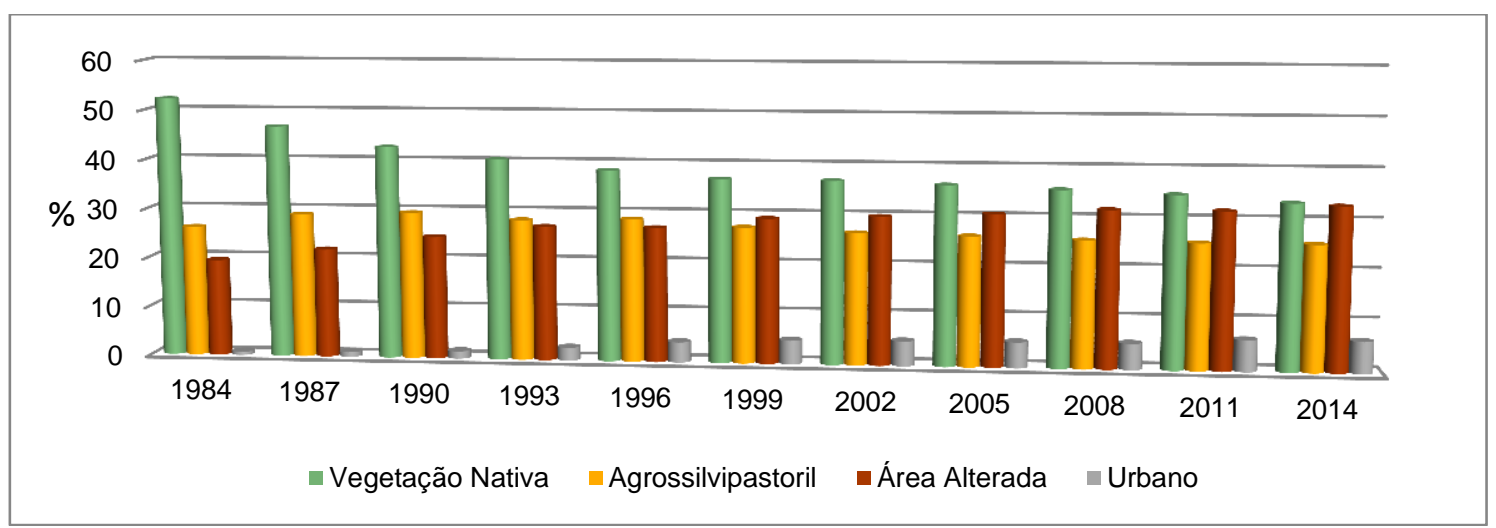

Figura 2.6 - Gráfico com as porcentagens das classes vegetação nativa, agrossilvipastoril, área alterada e área urbana.
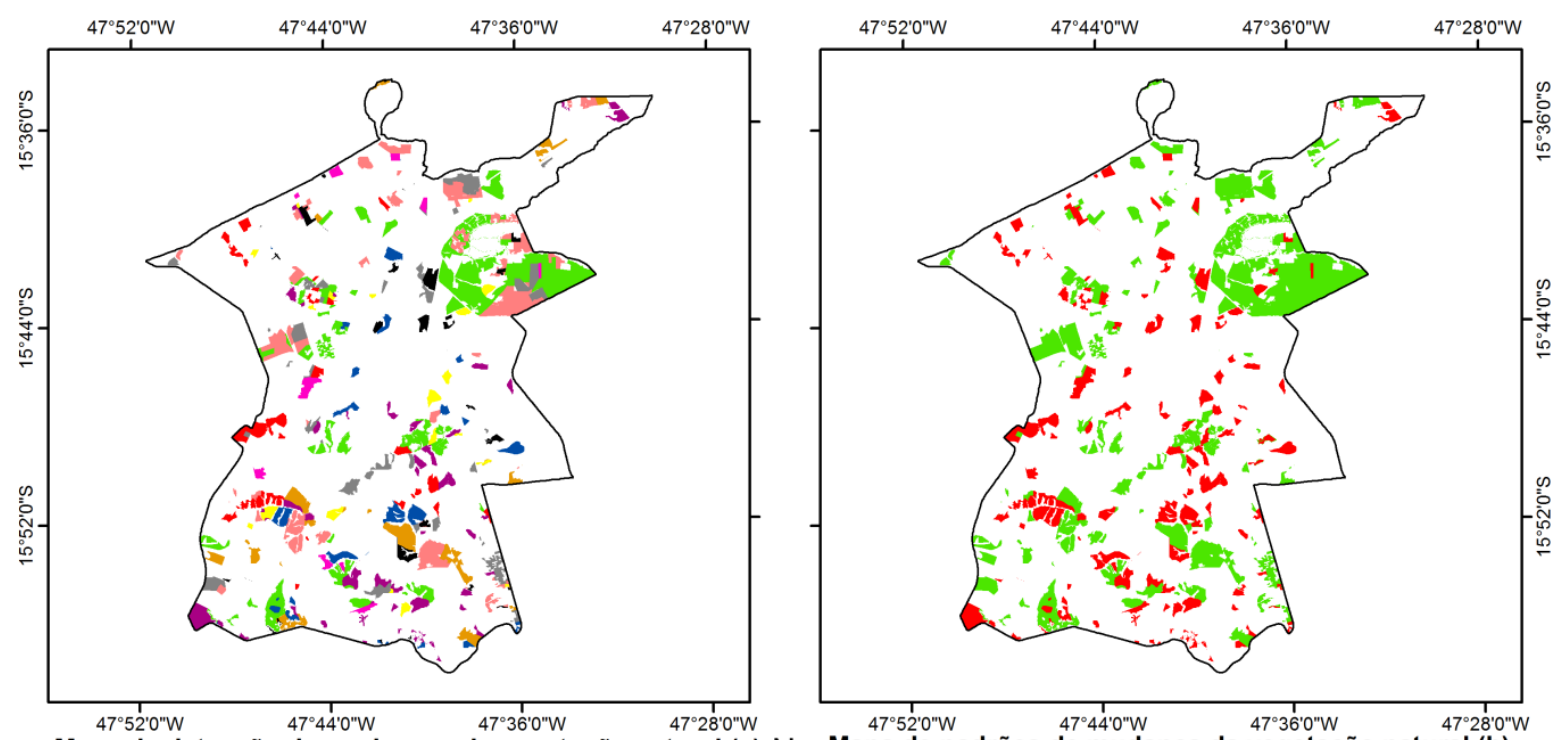

Mapa de detecção de mudanças da vegetação natural (a) $\mathrm{N}$ Mapa de padrões de mudança da vegetação natural (b)

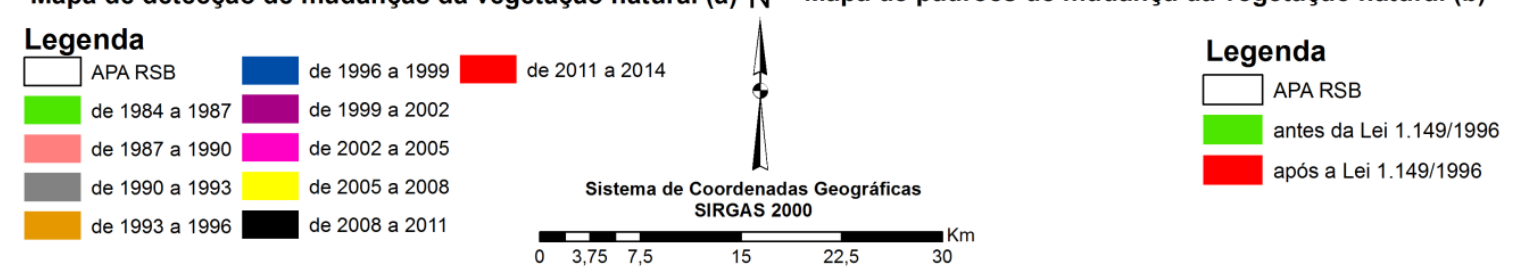

Figura 2.7 - Mapas de detecção (a) e padrões (b) de mudanças da vegetação natural na área de estudo entre os períodos do mapeamento.

$\mathrm{Na}$ avaliação dos padrões de mudanças da vegetação natural (Figura 2.7 b), foi considerado o período de vigência da Lei Distrital ํํ 1.149 de 11 de julho de 1996, que foi o primeiro rezoneamento da APA do Rio São Bartolomeu, revogada pela Lei Distrital o 5.344 de 19 de maio de 2014 (segundo rezoneamento). Neste sentido, observou-se que diante de toda a vegetação perdida entre 1984 a 2014 , 67,44\% foi suprimida entre 1984 a 1996, portanto, antes da Lei Distrital no 1.149 de 
11 de julho de 1996, enquanto 32,56\% desapareceram após o rezoneamento de 1996.

As tabulações cruzadas entre os períodos demonstram as porcentagens das áreas modificadas a cada intervalo em comparação ao anterior (Tabelas 2.4 a 2.13). Em consonância com os mapas da Figura 2.7, a tabulação cruzada revela que o período de maior impacto na vegetação natural se deu de 1984 a 1987 (Tabela 2.4), quando se percebeu uma alteração de $11,59 \%$ no intervalo. Assim como com a menor modificação percebida no cruzamento dos anos de 2002 a 2005 (Tabela 2.10), quando foi registrada uma oscilação de $1,61 \%$.

O intervalo de 1999 a 2002 registrou maior incremento de em área urbana, aumentando em 9,60\% sobre as demais classes (Tabela 2.9). Por sua vez, a Tabela 2.12 revela maior modificação na classe de áreas alteradas, na ordem de 5,95\%, observando que no período de 2008 a 2011 houve um decréscimo desta de 3,25\%, para a consolidação de área urbana.

A vegetação natural foi mais convertida em área alterada e atividade agrossilvipastoril, sendo que nos primeiros anos a predominância foi a conversão para a agricultura, porém, já nos anos noventa, o cenário é modificado e a vegetação natural passa a perder mais espaço para a área alterada.

Além de prevalecer na conversão da vegetação nativa, as áreas alteradas também avançaram sobre as atividades agrossilvipastoris, foi constatado que as áreas que deixaram de ser utilizadas na agricultura, foram em sua maioria classificadas como área alterada. Assim como, as áreas urbanas surgem com maior frequência das áreas anteriormente ocupadas por áreas alteradas.

Tais constatações ajudam a expor a situação de fracionamento dos espaços rurais na região de estudo, visando em muitos casos à formação de novos núcleos urbanos. Extinguindo a priori a vocação agrícola da área, convertendo-as em áreas alteradas, para posteriormente iniciar o processo de urbanização. Por fim, cabe destacar que ao longo da série histórica estudada houve uma pequena quantidade de áreas com algum tipo de uso da Terra convertidas em vegetação natural. 
Tabela 2.4: Detecção de mudança das classes de vegetação natural (VN), agrossilvipastoril (AgP), área alterada (AA), área urbana (AUrb), água e estrada de 1984 a 1987.

\begin{tabular}{|c|c|c|c|c|c|c|c|}
\hline \multirow{2}{*}{\multicolumn{2}{|c|}{ Porcentagens (\%) }} & \multicolumn{6}{|c|}{ Classes em 1984} \\
\hline & & VN & $\mathrm{AgP}$ & Aurb & AA & Água & Estrada \\
\hline \multirow{8}{*}{ 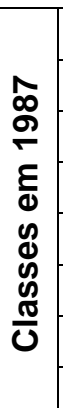 } & $V N$ & 88,41 & 1,37 & 0,00 & 0,92 & 0,00 & 0,00 \\
\hline & $A g P$ & 7,34 & 95,93 & 0,00 & 0,02 & 0,00 & 0,00 \\
\hline & Aurb & 0,10 & 0,00 & 100,00 & 1,25 & 0,00 & 0,00 \\
\hline & $A A$ & 4,15 & 2,70 & 0,00 & 97,78 & 0,00 & 0,00 \\
\hline & Água & 0,00 & 0,00 & 0,00 & 0,03 & 100,00 & 0,00 \\
\hline & Estrada & 0,00 & 0,00 & 0,00 & 0,00 & 0,00 & 100,00 \\
\hline & Total da Classe & 100,00 & 100,00 & 100,00 & 100,00 & 100,00 & 100,00 \\
\hline & Mudança na Classe & 11,59 & 4,07 & 0,00 & 2,22 & 0,00 & 0,00 \\
\hline
\end{tabular}

Tabela 2.5: Detecção de mudança das classes de vegetação natural (VN), agrossilvipastoril (AgP), área alterada (AA), área urbana (AUrb), água e estrada de 1987 a 1990.

\begin{tabular}{|c|c|c|c|c|c|c|c|}
\hline \multirow{2}{*}{\multicolumn{2}{|c|}{ Porcentagens (\%) }} & \multicolumn{6}{|c|}{ Classes em 1987} \\
\hline & & VN & AgP & Aurb & AA & Água & Estrada \\
\hline \multirow{8}{*}{ 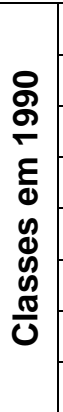 } & $V N$ & 91,50 & 0,00 & 0,00 & 0,00 & 0,00 & 0,00 \\
\hline & $A g P$ & 4,62 & 94,56 & 0,00 & 0,05 & 0,00 & 0,00 \\
\hline & Aurb & 0,14 & 0,05 & 94,57 & 2,30 & 0,00 & 0,00 \\
\hline & $A A$ & 3,73 & 5,39 & 5,43 & 97,65 & 0,00 & 0,00 \\
\hline & Água & 0,01 & 0,00 & 0,00 & 0,00 & 100,00 & 0,00 \\
\hline & Estrada & 0,00 & 0,00 & 0,00 & 0,00 & 0,00 & 100,00 \\
\hline & Total da Classe & 100,00 & 100,00 & 100,00 & 100,00 & 100,00 & 100,00 \\
\hline & Mudança na Classe & 8,51 & 5,44 & 5,43 & 2,35 & 0,00 & 0,00 \\
\hline
\end{tabular}

Tabela 2.6: Detecção de mudança das classes de vegetação natural (VN), agrossilvipastoril (AgP), área alterada (AA), área urbana (AUrb), água e estrada de 1990 a 1993.

\begin{tabular}{|c|c|c|c|c|c|c|c|}
\hline \multirow{2}{*}{\multicolumn{2}{|c|}{ Porcentagens (\%) }} & \multicolumn{6}{|c|}{ Classes em 1990} \\
\hline & & VN & $\mathrm{AgP}$ & Aurb & AA & Água & Estrada \\
\hline \multirow{8}{*}{ 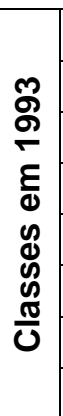 } & $V N$ & 94,41 & 0,12 & 0,00 & 0,25 & 0,00 & 0,00 \\
\hline & $A g P$ & 1,44 & 93,25 & 0,00 & 0,68 & 0,00 & 0,00 \\
\hline & Aurb & 0,52 & 0,34 & 92,93 & 3,61 & 0,00 & 0,00 \\
\hline & $A A$ & 3,62 & 6,28 & 7,07 & 95,43 & 0,00 & 0,00 \\
\hline & Água & 0,01 & 0,01 & 0,00 & 0,03 & 100,00 & 0,00 \\
\hline & Estrada & 0,00 & 0,00 & 0,00 & 0,00 & 0,00 & 100,00 \\
\hline & Total da Classe & 100,00 & 100,00 & 100,00 & 100,00 & 100,00 & 100,00 \\
\hline & Mudança na Classe & 5,59 & 6,75 & 7,07 & 4,57 & 0,00 & 0,00 \\
\hline
\end{tabular}

Tabela 2.7: Detecção de mudança das classes de vegetação natural (VN), agrossilvipastoril (AgP), área alterada (AA), área urbana (AUrb), água e estrada de 1993 a 1996.

\begin{tabular}{|c|c|c|c|c|c|c|c|}
\hline \multirow{2}{*}{\multicolumn{2}{|c|}{\begin{tabular}{|l|} 
Porcentagens (\%) \\
\end{tabular}}} & \multicolumn{6}{|c|}{ Classes em 1993} \\
\hline & & VN & $\mathrm{AgP}$ & Aurb & AA & Água & Estrada \\
\hline \multirow{8}{*}{ 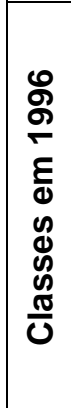 } & $V N$ & 95,22 & 0,00 & 0,00 & 0,00 & 0,00 & 0,00 \\
\hline & $A g P$ & 2,52 & 97,91 & 0,00 & 0,00 & 0,00 & 0,00 \\
\hline & Aurb & 0,08 & 0,00 & 99,37 & 5,43 & 0,00 & 0,00 \\
\hline & $A A$ & 2,17 & 2,08 & 0,63 & 94,55 & 0,00 & 0,00 \\
\hline & Água & 0,01 & 0,01 & 0,00 & 0,02 & 100,00 & 0,00 \\
\hline & Estrada & 0,00 & 0,00 & 0,00 & 0,00 & 0,00 & 100,00 \\
\hline & Total da Classe & 100,00 & 100,00 & 100,00 & 100,00 & 100,00 & 100,00 \\
\hline & Mudança na Classe & 4,78 & 2,09 & 0,63 & 5,46 & 0,00 & 0,00 \\
\hline
\end{tabular}


Tabela 2.8: Detecção de mudança das classes de vegetação natural (VN), agrossilvipastoril (AgP), área alterada (AA), área urbana (AUrb), água e estrada de 1996 a 1999.

\begin{tabular}{|c|c|c|c|c|c|c|c|}
\hline \multirow{2}{*}{\multicolumn{2}{|c|}{ Porcentagens (\%) }} & \multicolumn{6}{|c|}{ Classes em 1996} \\
\hline & & VN & AgP & Aurb & AA & Água & Estrada \\
\hline \multirow{8}{*}{ 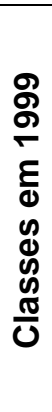 } & $V N$ & 96,09 & 0,00 & 0,00 & 0,00 & 0,00 & 0,00 \\
\hline & $A g P$ & 1,66 & 93,03 & 0,00 & 0,02 & 0,00 & 0,00 \\
\hline & Aurb & 0,07 & 0,00 & 99,41 & 2,56 & 0,00 & 0,00 \\
\hline & $A A$ & 2,18 & 6,94 & 0,59 & 97,27 & 0,00 & 0,00 \\
\hline & Água & 0,00 & 0,03 & 0,00 & 0,15 & 100,00 & 0,00 \\
\hline & Estrada & 0,00 & 0,00 & 0,00 & 0,00 & 0,00 & 100,00 \\
\hline & Total da Classe & 100,00 & 100,00 & 100,00 & 100,00 & 100,00 & 100,00 \\
\hline & Mudança na Classe & 3,91 & 6,98 & 0,59 & 2,73 & 0,00 & 0,00 \\
\hline
\end{tabular}

Tabela 2.9: Detecção de mudança das classes de vegetação natural (VN), agrossilvipastoril (AgP), área alterada (AA), área urbana (AUrb), água e estrada de 1999 a 2002.

\begin{tabular}{|c|c|c|c|c|c|c|c|}
\hline \multirow{2}{*}{\multicolumn{2}{|c|}{ Porcentagens (\%) }} & \multicolumn{6}{|c|}{ Classes em 1999} \\
\hline & & VN & AgP & Aurb & AA & Água & Estrada \\
\hline \multirow{8}{*}{ 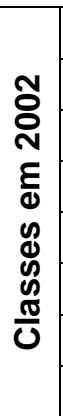 } & $V N$ & 94,68 & 2,16 & 4,30 & 0,20 & 0,00 & 0,00 \\
\hline & $A g P$ & 1,31 & 90,76 & 4,18 & 0,08 & 0,00 & 0,00 \\
\hline & Aurb & 3,97 & 7,05 & 90,40 & 1,97 & 0,00 & 0,00 \\
\hline & $A A$ & 0,04 & 0,02 & 1,10 & 97,75 & 0,00 & 0,00 \\
\hline & Água & 0,00 & 0,01 & 0,02 & 0,00 & 100,00 & 0,00 \\
\hline & Estrada & 0,00 & 0,00 & 0,00 & 0,00 & 0,00 & 100,00 \\
\hline & Total da Classe & 100,00 & 100,00 & 100,00 & 100,00 & 100,00 & 100,00 \\
\hline & Mudança na Classe & 5,32 & 9,24 & 9,60 & 2,25 & 0,00 & 0,00 \\
\hline
\end{tabular}

Tabela 2.10: Detecção de mudança das classes de vegetação natural (VN), agrossilvipastoril (AgP), área alterada (AA), área urbana (AUrb), água e estrada de 2002 a 2005.

\begin{tabular}{|c|c|c|c|c|c|c|c|}
\hline \multirow{2}{*}{\multicolumn{2}{|c|}{ Porcentagens (\%) }} & \multicolumn{6}{|c|}{ Classes em 2002} \\
\hline & & VN & AgP & Aurb & AA & Água & Estrada \\
\hline \multirow{8}{*}{ 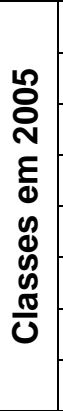 } & $V N$ & 98,40 & 0,00 & 0,00 & 0,00 & 0,00 & 0,00 \\
\hline & $A g P$ & 0,37 & 98,14 & 0,00 & 0,00 & 0,00 & 0,00 \\
\hline & Aurb & 0,03 & 0,01 & 100,00 & 0,62 & 0,00 & 0,00 \\
\hline & $A A$ & 1,20 & 1,85 & 0,00 & 99,37 & 0,00 & 0,00 \\
\hline & Água & 0,00 & 0,00 & 0,00 & 0,01 & 100,00 & 0,00 \\
\hline & Estrada & 0,00 & 0,00 & 0,00 & 0,00 & 0,00 & 100,00 \\
\hline & Total da Classe & 100,00 & 100,00 & 100,00 & 100,00 & 100,00 & 100,00 \\
\hline & Mudança na Classe & 1,61 & 1,86 & 0,00 & 0,63 & 0,00 & 0,00 \\
\hline
\end{tabular}

Tabela 2.11: Detecção de mudança das classes de vegetação natural (VN), agrossilvipastoril (AgP), área alterada (AA), área urbana (AUrb), água e estrada de 2005 a 2008.

\begin{tabular}{|c|c|c|c|c|c|c|c|}
\hline \multirow{2}{*}{\multicolumn{2}{|c|}{ Porcentagens (\%) }} & \multicolumn{6}{|c|}{ Classes em 2005} \\
\hline & & VN & AgP & Aurb & AA & Água & Estrada \\
\hline \multirow{8}{*}{ 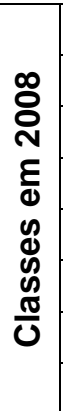 } & $V N$ & 97,86 & 0,00 & 0,25 & 0,00 & 0,00 & 0,00 \\
\hline & $A g P$ & 0,16 & 96,67 & 0,94 & 0,00 & 0,00 & 0,00 \\
\hline & Aurb & 1,98 & 3,31 & 98,53 & 0,00 & 0,00 & 0,00 \\
\hline & $A A$ & 0,00 & 0,01 & 0,25 & 100,00 & 0,00 & 0,00 \\
\hline & Água & 0,00 & 0,01 & 0,03 & 0,00 & 100,00 & 0,00 \\
\hline & Estrada & 0,00 & 0,00 & 0,00 & 0,00 & 0,00 & 100,00 \\
\hline & Total da Classe & 100,00 & 100,00 & 100,00 & 100,00 & 100,00 & 100,00 \\
\hline & Mudança na Classe & 2,14 & 3,34 & 1,48 & 0,00 & 0,00 & 0,00 \\
\hline
\end{tabular}


Tabela 2.12: Detecção de mudança das classes de vegetação natural (VN), agrossilvipastoril (AgP), área alterada (AA), área urbana (AUrb), água e estrada de 2008 a 2011.

\begin{tabular}{|c|c|c|c|c|c|c|c|}
\hline \multirow{2}{*}{\multicolumn{2}{|c|}{ Porcentagens (\%) }} & \multicolumn{6}{|c|}{ Classes em 2008} \\
\hline & & VN & AgP & Aurb & AA & Água & Estrada \\
\hline \multirow{8}{*}{ 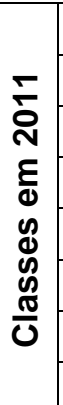 } & $V N$ & 95,42 & 0,44 & 0,23 & 1,83 & 15,32 & 0,00 \\
\hline & $A g P$ & 1,00 & 96,51 & 0,02 & 0,39 & 1,61 & 0,00 \\
\hline & Aurb & 0,08 & 0,44 & 98,96 & 3,25 & 0,11 & 0,00 \\
\hline & $A A$ & 3,00 & 2,49 & 0,67 & 94,05 & 6,26 & 0,00 \\
\hline & Água & 0,50 & 0,12 & 0,12 & 0,48 & 76,70 & 0,00 \\
\hline & Estrada & 0,00 & 0,00 & 0,00 & 0,00 & 0,00 & 100,00 \\
\hline & Total da Classe & 100,00 & 100,00 & 100,00 & 100,00 & 100,00 & 100,00 \\
\hline & Mudança na Classe & 4,59 & 3,49 & 1,04 & 5,95 & 23,30 & 0,00 \\
\hline
\end{tabular}

Tabela 2.13: Detecção de mudança das classes de vegetação natural (VN), agrossilvipastoril (AgP), área alterada (AA), área urbana (AUrb), água e estrada de 2011 a 2014.

\begin{tabular}{|c|c|c|c|c|c|c|c|}
\hline \multirow{2}{*}{\multicolumn{2}{|c|}{ Porcentagens (\%) }} & \multicolumn{6}{|c|}{ Classes em 2011} \\
\hline & & VN & AgP & Aurb & AA & Água & Estrada \\
\hline \multirow{8}{*}{ 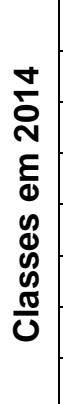 } & $V N$ & 95,96 & 0,00 & 0,00 & 0,00 & 0,00 & 0,00 \\
\hline & $A g P$ & 0,32 & 99,98 & 0,00 & 0,00 & 0,00 & 0,00 \\
\hline & Aurb & 0,04 & 0,00 & 100,00 & 0,13 & 0,00 & 0,00 \\
\hline & $A A$ & 3,67 & 0,00 & 0,00 & 99,75 & 0,00 & 0,00 \\
\hline & Água & 0,01 & 0,02 & 0,00 & 0,12 & 100,00 & 0,00 \\
\hline & Estrada & 0,00 & 0,00 & 0,00 & 0,00 & 0,00 & 100,00 \\
\hline & Total da Classe & 100,00 & 100,00 & 100,00 & 100,00 & 100,00 & 100,00 \\
\hline & Mudança na Classe & 4,04 & 0,02 & 0,00 & 0,26 & 0,00 & 0,00 \\
\hline
\end{tabular}

\subsubsection{Fatores que condicionam a ocupação humana}

Os condicionantes da ocupação humana incluem fatores naturais (declividade, pedologia e clima) e políticos (normas que regem o uso do espaço). Dentre os fatores ambientais, a declividade do terreno é um importante fator natural que norteia o uso do solo da APA (Figura 2.8). As áreas com maior declividade são menos apropriadas para o uso agrícola e construção de edificações, tornando-se mais preservadas (Figura 2.9). Em 2014, o uso antrópico da área com declividade acima de $25^{\circ}$ (protegidas pela Lei Federal 12.651/2012) era $16.32 \%$, enquanto os demais $83,68 \%$ se mantiveram cobertos por vegetação natural. Enquanto nas áreas com declividade abaixo de $25^{\circ}, 31,69 \%$ se mantiveram cobertos por vegetação nativa.

As áreas agrícolas estão localizadas predominantemente em terrenos planos, com declividade que não ultrapassa 8,5․ Na APA do Rio São Bartolomeu predomina o cultivo agrícola com regime de sequeiro, havendo apenas um pivô central instalado em 2014, configuração distinta da encontrada na região do Rio Preto, localizada a leste da poligonal estudada (FILHO, 2005). 


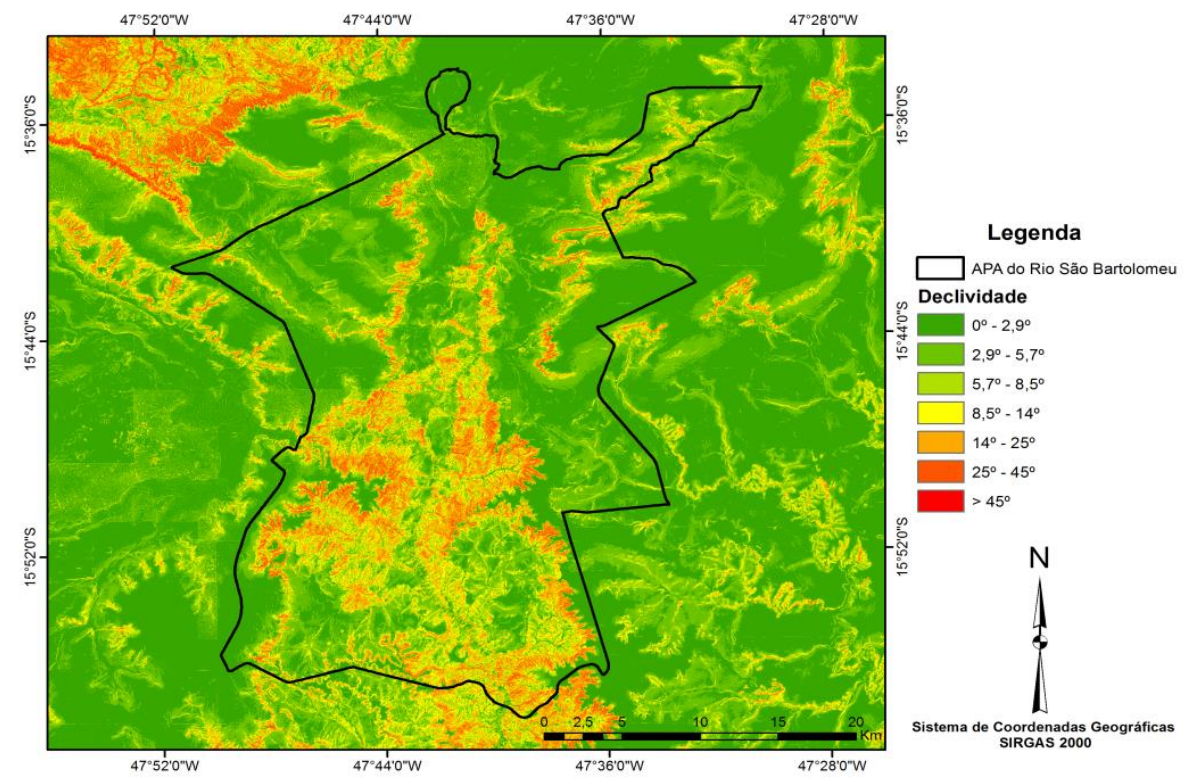

Figura 2.8 - Análise de declividade da região de estudo.

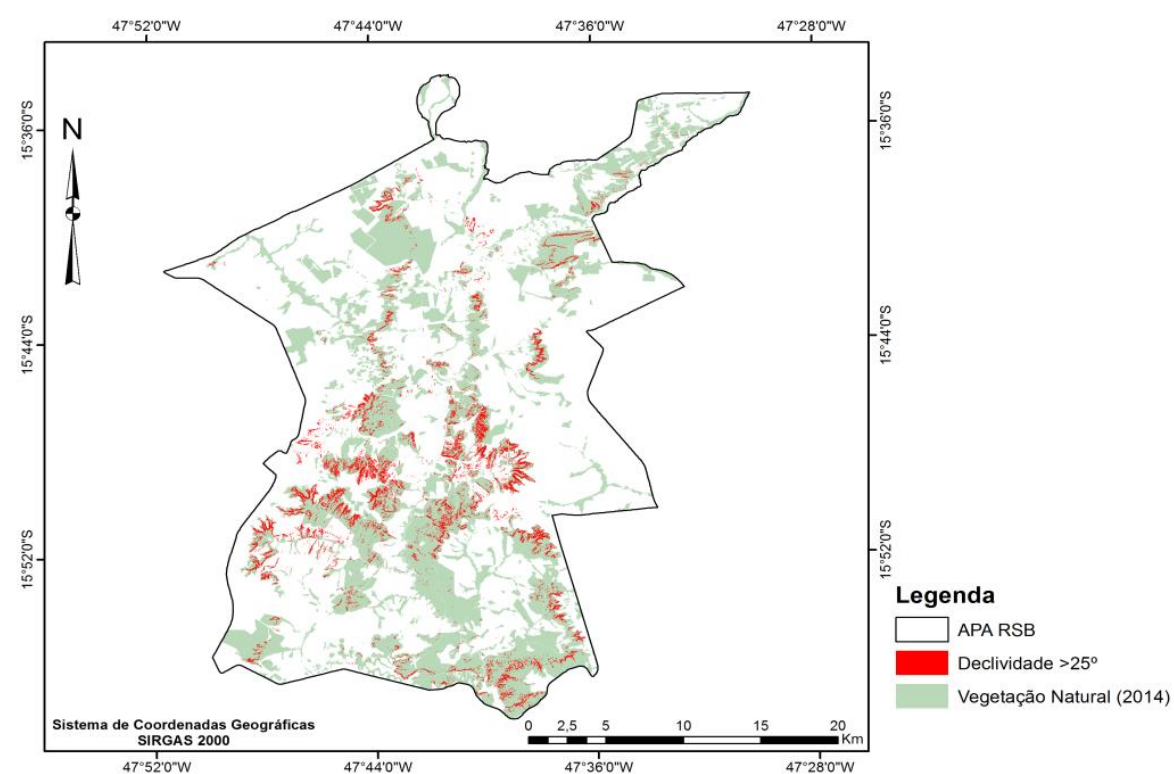

Figura 2.9 - Relação de declividade com a manutenção de vegetação natural.

O cenário agrícola do DF é definido pela configuração fundiária, onde uma grande parcela de imóveis rurais está em propriedade do Estado, funcionando em regime de concessão entre o poder público e pessoas físicas condicionadas à manutenção da atividade agrícola (Figura 2.10). As atividades agrossilvipastoris do leste da APA do Rio São Bartolomeu estão funcionando sob tal regime. Em 2014, o Estado possuía 13.262,20ha em regime de concessão dos 21.359,85ha de área ocupada por atividades agrossilvipastoris (Tabela 2.2). Portanto em 2014, 62\% da área agrícola estavam em um regime de uso definido pelo Estado. 


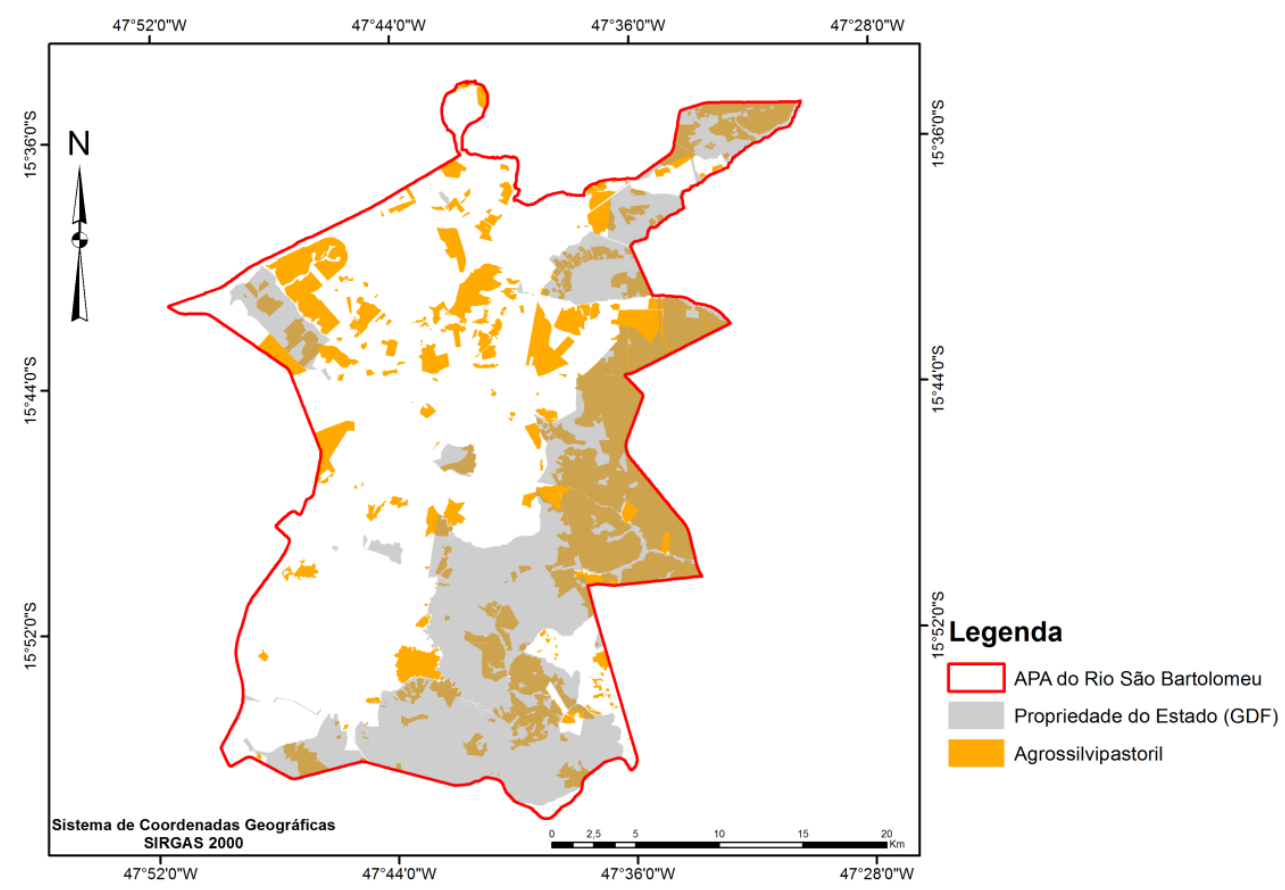

Figura 2.10 - Correlação do uso agrícola com a propriedade dos imóveis rurais.

O crescimento da urbanização na unidade de conservação ocorreu principalmente na porção oeste, limítrofe a Região Administrativa de Brasília - RA I. O crescimento urbano na APA é condicionado pela Lei Complementar n־803 de 25 de abril de 2009, que aprova a revisão do PDOT. O Art. 65ำ da presente lei estabelece e conceitua a Macrozona Urbana como o espaço que deverá contribuir para o desenvolvimento sustentável do território a partir das atividades dos setores secundário (sistema industrial) e terciário (prestadores de serviços), não excluída a presença de atividades do setor primário (agricultura e pecuária). Conforme esta lei, a Macrozona Urbana possui um potencial de ocupar 25,59\% da APA do Rio São Bartolomeu. Em 2014, a Macrozona Urbana ocupava 5.407,79 ha (6,45\%) da APA do Rio São Bartolomeu (Figura 2.10). Observa-se que em 2014 dos 28.132,77ha de vegetação natural da APA, 6.033,82ha (21,44\%) estão na Macrozona Urbana, logo, diretamente ameaçados por empreendimentos urbanos que poderão ser instalados neste espaço (Figura 2.11). 


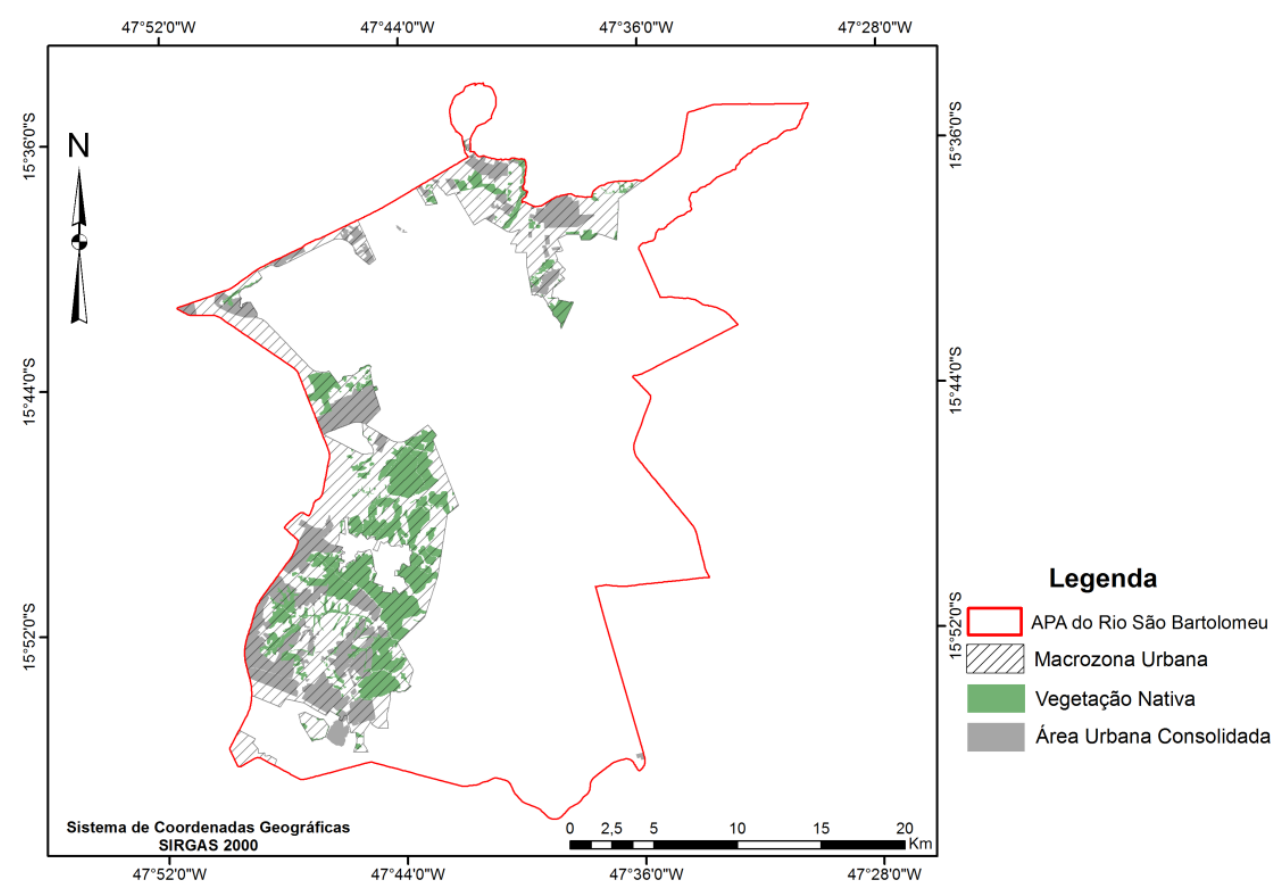

Figura 2.11 - Macrozona Urbana na APA do Rio São Bartolomeu.

Além do PDOT, que orienta a ocupação do solo em todo o DF, a APA do Rio São Bartolomeu tem regramento especifico que norteia o uso do solo. Dentre as normas editadas durante a história desta unidade de conservação, destacamos a Lei Distrital n-1.149 de 11 de julho de 1996, que dispõe sobre o rezoneamento ambiental da Área de Proteção Ambiental da bacia do rio São Bartolomeu e a Lei Distrital n-5.344 de 19 de maio de 2014, que dispõe sobre o rezoneamento ambiental e o plano de manejo da Área de Proteção Ambiental da Bacia do Rio São Bartolomeu, sendo que a lei de 2014 revogou e substituiu a lei de 1996. Ainda que a lei de 1996 tenha sido revogada, para a presente discussão é importante registra-la, possibilitando uma analise sobre a condução do poder público frente ao espaço protegido.

Conforme a Lei Distrital no 1.149 de 11 de julho de 1996, as Zonas de Proteção dos Reservatórios (ZPR) eram voltadas a conservação e manutenção de atividades agrícolas, a Zona de Uso Restrito (ZUR) era destinada a conservação e atividades agrícolas extensivas, permitindo alguns empreendimentos de mineração preexistentes e a Zona de Vida Silvestre (ZVS) tinha foco na proteção das espécies nativas da flora e fauna. Na atualização do rezoneamento, a Lei Distrital ํㅜ 5.344 de 19 de maio de 2014 trouxe a Zona de Conservação de Vida Silvestre (ZCVS) como a destinada à conservação dos recursos naturais e à integridade dos ecossistemas e a Zona de Preservação de Vida Silvestre (ZPVS) como o espaço voltado a 
preservação dos recursos ecológicos e genéticos, além da integridade dos ecossistemas.

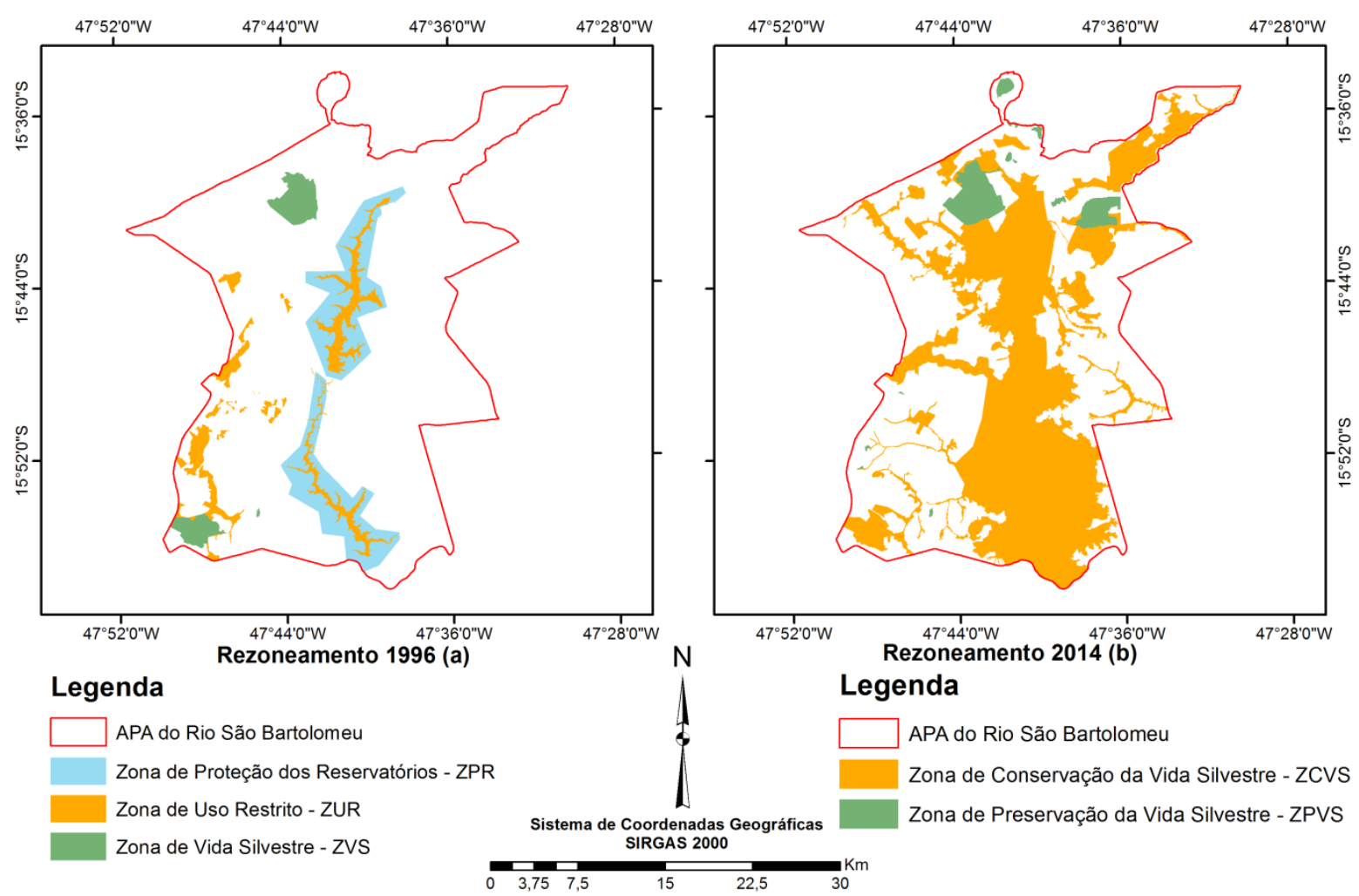

Figura 2.12 - Zonas de maior restrição ambiental na Área de Proteção Ambiental do Rio São Bartolomeu.

A comparação dos rezoneamentos evidencia que as áreas de maior restrição ambiental tiveram um acréscimo de 14.837,69ha em 1996 para 38.480,14ha em 2014, refletindo uma preocupação com a manutenção da vegetação nativa e consolidação dos corredores ecológicos. O aumento do rigor na restrição de uso do solo na unidade de conservação é consequência da fragilidade das áreas nativas quando confrontadas com o interesse imobiliário, seja para ocupações rurais ou urbanas. Ainda tratando de vegetação nativa no que se refere às normas de rezoneamento, verificou-se quanto desta classe estava presente nas zonas de maior restrição ambiental no oportuno da publicação das leis. 


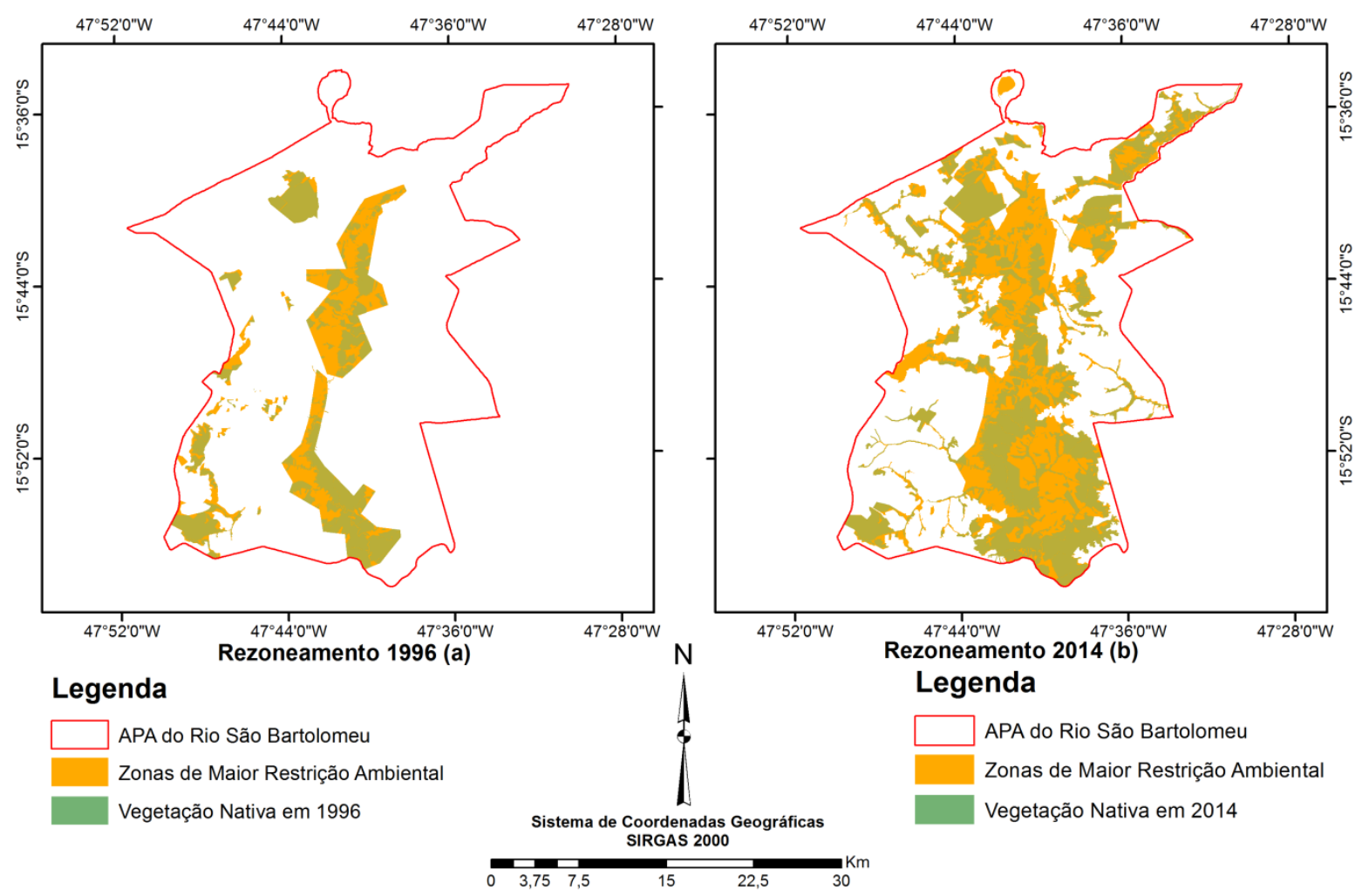

Figura 2.13 - Zonas de maior restrição ambiental na APA do Rio São Bartolomeu.

A vegetação nativa em 1996 ocupava uma área de 8.100,82ha em relação à zona de maior restrição ambiental que tinha área de 14.837,69ha, correspondendo a 54,59\% (Figura 2.13). Em 2014, dos 38.480,14 ha de maior restrição ambiental, 20.480,95ha estão cobertos por vegetação natural, representando 53,22\% destas zonas mais restritas. Além disso, $25,01 \%$ de vegetação nativa de toda a APA estavam em área de maior proteção ambiental em 1996, essa porcentagem sobe para $72,80 \%$ em 2014, expressando uma maior intenção do poder público em conservar a vegetação nativa na unidade de conservação. No entanto, vale registrar que em geral, tais áreas não conflitam com a Macrozona Urbana definida pelo plano diretor vigente (Lei Complementar nำ03/2009), mantendo aquela vegetação nativa passiva da antropização pela ocupação urbana (Figura 2.11).

\subsection{DISCUSSÃO}

A partir dos resultados, em se tratando de uma área protegida, a perda de vegetação nativa chama atenção, na comparação com os estudos de Castro et al. (2013) no município de Formosa do Rio Preto - BA e Spagnolo et al. (2012) em São Desidério - BA, em regiões com vocações agrícolas, as perdas na APA do Rio São 
Bartolomeu são significativas. Conforme Castro et al. (2013), entre os anos de 1988 à 2008 o município de Formosa do Rio Preto - BA perdeu 26,00\% da cobertura natural e Spagnolo et al. (2012) em São Desidério - BA registrou menos 36,24\% desta classe entre 1984 à 2008, enquanto a APA do Rio São Bartolomeu perdeu $18,80 \%$ de 1984 à 2014.

Por sua vez, Cocco et al. (2015) fez a avaliação da cobertura natural na Bacia Hidrográfica do Rio Diamantino, no estado do Mato Grosso - Brasil, que é uma área de uso diversificado, onde foi detectado que em 1993 a região tinha 88,58\% de vegetação nativa, porém, em 2013 tal classe cobria 62,49\% do território, registrando uma perda de $26,09 \%$ do remanescente de vegetação nativa em vinte anos, também maior que o índice constatado pelo presente estudo.

O índice de cobertura da vegetação silvestre encontrado na APA de estudo em 2014 foi de 33,53\%, portanto, superior aos 28,49\% encontrados por Souza et al. (2014) na APA Coqueiral, em Coqueiral - MG, porém, inferior aos 82,04\% da APA de Guaraqueçaba no Município de Guaraqueçaba - PR, publicado por Muller \& Bessa (2008) e aos 82,22\% encontrados por Rezende et al. (2011) na APA Cachoeira das Andorinhas, em Ouro Preto - MG.

No mesmo período do presente estudo, a região oeste da Bahia passou pela consolidação das atividades agrossilvipastoris, como pode ser visto em Flores et al. (2012), quando identificou que em 2008 a agricultura passou a ocupar $24,3 \%$ do município de Barreiras - BA, enquanto Menke et al. (2009) detectou que esta classe ocupava 50,00\% do território de Luiz Eduardo Magalhães - BA no mesmo ano e Spagnolo et al. (2012) encontrou cerca de 35,00\% da área ocupada por agricultura também em 2008 em São Desidério - BA. Na APA do Rio São Bartolomeu, com menor vocação agrícola, 25,72\% estavam ocupados por agricultura em 2008, mostrando que a unidade de conservação é impactada pelas atividades agrossilvipastoris em índices próximos as áreas não protegidas.

Conforme os dados que demonstram a expansão urbana, foi detectado que partiu-se de uma ocupação de 0,66\% em 1984, praticamente inexistente, para os $6,45 \%$ em 2014, com previsibilidade legal de avançar para mais que $25,00 \%$. 0 cenário pode avançar aos índices encontrados por Oliveira \& Aquino (2015), no bairro Vale do Gavião, município de Teresina - PI, onde a área urbana passou de 0,73\% à 19,18\% no período de 1985 à 2010.

Tanto o bairro Vale do Gavião no município de Teresina - PI, como a área de estudo, são regiões que compõe o entorno de grandes cidades, focos da 
especulação e interesse imobiliário, no entanto, o bairro Vale do Gavião não é uma área protegida como a APA do Rio São Bartolomeu.

\subsection{CONCLUSÃO}

A APA do Rio São Bartolomeu, uma das primeiras unidades de conservação criada no Brasil, sofreu durante os primeiros trinta anos de existência com a pressão antrópica, principalmente pelo interesse imobiliário, seja para uso rural ou urbano, em detrimento aos remanescentes de vegetação nativa, que perderam 15.775,83ha, que representam $18,80 \%$ do seu território. Tal constatação é acompanhada pelo crescimento do fracionamento do solo e urbanização da região, aumentando a demanda pelo recurso hídrico e por consequência dos pontos de reservatórios e represamentos de água na APA, que cresceram de 44 para 448 no período 1984 2014. Portanto, a pressão antrópica antecede a criação da unidade de conservação, porém agravou-se nos anos seguintes, diante da complexa situação fundiária do Distrito Federal, sendo o espaço diretamente ameaçado pela especulação fundiária.

Referente à política pública, destaca-se o previsto no PDOT-2009 (Lei Complementar n803/2009), que encaminha 25,59\% da APA do Rio São Bartolomeu a urbanização, colocando em risco a manutenção de 6.033,82ha que em 2014 estavam na área urbanizável. Frente ao previsto pela Lei Distrital n 30.031/2002 em se manter $50 \%$ do solo do DF coberto por vegetação silvestre, até 1984 a APA do Rio São Bartolomeu atendia o estabelecido na norma, porém, a partir de 1987 índices abaixo de 50\% foram registrando, com uma tendência de queda contínua até 2014. Por outro lado, há de se reconhecer os avanços da Lei Distrital n 5.344/2014, que elevou para $45,86 \%$ a área de maior restrição ambiental nesta unidade de conservação, que inclusive abrigava $72,80 \%$ da vegetação natural existente em 2014. Isto expressa uma maior compreensão do poder público sobre o espaço e principalmente maior preocupação em deter as supressões de vegetação nativa. 


\section{REFERÊNCIAS}

AGÊNCIA DE DESENVOLVIMENTO DO DISTRITO FEDERAL - TERRACAP. Termo de referência para contratação de levantamento aerofotogramétrico digital para geração de ortofotos do território do Distrito Federal e entorno imediato. Brasília - DF, 2012.

ANDERSON, L. O.; SHIMABUKURO, Y. E. ; LIMA, A.; MEDEIROS, J. S.; Mapeamento da cobertura da terra do estado do Mato Grosso através da Utilização de dados multitemporais do sensor MODIS; Geografia (Rio Claro); Rio Claro, SP, v. 30, n.2, p. 365-380, 2005.

BARBOSA, R.I.; CAMPOS, C.; Detection and geographical distribution of clearing areas in the savannas ('lavrado') of Roraima using Google Earth web tool; Journal of Geography and Regional Planning; 2011.

BORLAUG, N.E.; Feeding a world of 10 billion people: the miracle ahead. In: R. Bailey (ed.). Global warming and other eco-myths. pp. 29-60. Competitive Enterprise Institute, Roseville, EUA, 2002.

BRASIL; Decreto 88.940, de 07 de novembro de 1983; Criação das Áreas de Proteção Ambiental do Rio São Bartolomeu e do Rio Descoberto.

BRASIL; Lei 12.651, de 25 de maio de 2012; Lei de proteção da vegetação nativa.

BRASIL; Lei 6.902, de 27 de abril de 1981; Criação de Estações Ecológicas e Áreas de Proteção Ambiental.

BRASIL; Lei 6.938, de 31 de agsto de 1981; Sistema Nacional de Meio Ambiente SISNAMA.

BRASIL; Lei 9.985, de 18 de julho de 2000; Sistema Nacional de Unidades de Conservação - SNUC.

CAMPOS, J. E. G.; Hidrogeologia do Distrito Federal: Bases para a gestão dos recursos hídricos subterrâneos; Revista Brasileira de Geociências; São Paulo SP; v. 34, n. 1, p. 41 - 48; 2004.

CARDOSO, M R. D.; MARCUZZO, F. F. N.; BARROS, J. R.; Caracterização da temperatura do ar no Estado do Goiás e no Distrito Federal. Revista Brasileira de Climatologia, v. XI, p. 119-134, 2013.

CASTRO, A. S.; GOMES, R. A. T.; GUIMARÃES, R. F.; CARVALHO JUNIOR, O. A.; MARTINS, E. S.; Análise da dinâmica da paisagem no município de Formosa do Rio Preto (BA). Espaço e Geografia (UnB), v. 16, p. 307-323, 2013.

COCCO, J.; RIBEIRO, H. V. ; GALVANIN, E. A. S.; Intensity of anthropic action in the Diamantino river Sub-basin, Mato Grosso State/Brazil. Geografia (Rio Claro. Impresso), v. 40, p. 71-84, 2015.

DE BRUIN, S.; Querying probabilistic land cover data using fuzzy set theory. International Journal of Geographical Information Sciences; v.14; p.359-372; 2000. 
DISTRITO FEDERAL; Lei Complementar no803 de 25 de abril de 2009; Aprova a revisão do Plano Diretor de Ordenamento Territorial do Distrito Federal - PDOT.

DISTRITO FEDERAL; Lei o 1.149 de 11 de julho de 1996; Dispõe sobre o rezoneamento ambiental da Área de Proteção Ambiental da bacia do rio São Bartolomeu.

DISTRITO FEDERAL; Lei nํ․031, de 18 de julho de 2002; Institui a Política Florestal do Distrito Federal.

DISTRITO FEDERAL; Lei ํ⒌344 de 19 de maio de 2014; Dispõe sobre o Rezoneamento Ambiental e o Plano de Manejo da Área de Proteção Ambiental da Bacia do Rio São Bartolomeu.

EITEN, G.; Vegetação; In: NOVAES PINTO, M (org); Cerrado: caracterização, ocupação e perspectivas; 2. ed., Brasília: Edunb/Sematec; Brasília - DF; 1993.

FILHO, B. S. S.; Impacto da Revisão do Código Florestal - Como viabilizar o grande desafio adiante, Secretaria de Assuntos Estratégicos, Brasília (DF), 2013.

FILHO, J. A. S. Carta de Fragilidade Ambiental do Alto da Bacia do Rio Preto. Universidade Federal de Minas Gerais (UFMG). Departamento de Geografia. Belo Horizonte - MG, 2005.

FLORENZANO, T.G. Sensoriamento Remoto para Geomorfologia. In: Florenzano, T.G (Org.), Geomorfologia: conceitos e tecnologias atuais. São Paulo: Oficina de Textos, 2008.

FLORES, P. M.; GUIMARÃES, R. F.; CARVALHO JÚNIOR, O. A.; GOMES, R. A. T.; Análise multitemporal da expansão agrícola no município de Barreiras - Bahia (1988 - 2008). Campo - Território, v. 7, p. 1-19, 2012.

FREITAS, C. F. S.; Proteção Ambiental e Direito à Cidade no processo de expansão urbana do Distrito Federal: até que ponto existe um conflito? Tese de Doutorado Universidade de Brasília - UnB; Brasília-DF, 2009.

HOWARTH, P. J.; WICKWARE, G. M. Procedures for change detection using Landsat digital data. International Journal of Remote Sensing, v. 2, p. 277-291, 1981.

INPE - Instituto Nacional de Pesquisas Espaciais; Catálogo de Imagens; Disponível em: <http://www.dgi.inpe.br/siteDgi/portugues/index.php> Acesso em: 08 outubro 2015.

MAS, J. F. Monitoring land-cover changes: a comparison of change detection echniques. International Journal of Remote Sensing, v.20, p. 139-152, 1999.

MENKE, A. B.; CARVALHO JUNIOR, O. A.; GOMES, R. A. T.; MARTINS, E. S.; OLIVEIRA, S. N.; Análise das mudanças do uso agrícola da terra a partir de dados de sensoriamento remoto multitemporal no município de Luis Eduardo Magalhães (BA - Brasil). Sociedade \& Natureza (UFU. Online), v. 21, p. 315-326, 2009.

MÜLLER, A. C. P.; BESSA JUNIOR, O.; Variação temporal e espacial da cobertura vegetal da floresta ombrófila densa da Área de Proteção Ambiental de 
Guaraqueçaba, no Estado do Paraná, Brasil. Desenvolvimento e Meio Ambiente (UFPR), v. 17, p. 111-120, 2008.

MUNYATI, C.; Wetland change detection on the Kafue Flats, Zambia, by classification of a multitemporal remote sensing image dataset; International Journal of Remote Sensing; v.21; n.9; p. 1787/1806; 2000.

OLIVEIRA, C. C. E.; AQUINO, C. M. S.; Analise da expansão urbana em Teresina e no bairro Vale do Gavião e suas implicações na cobertura vegetal nos anos de 1985 e 2010 (ISSN 2316-8056); Revista da Casa da Geografia de Sobral (RCGS), v. 17, p. $68-84,2015$.

OLIVEIRA, S. N.; CARVALHO JÚNIOR, O. A.; GOMES, R. A. T.; GUIMARÃES, R. F.; MARTINS, E. S.; Detecção de mudança do uso e cobertura da terra usando o método de pós-classificação na fronteira agrícola do Oeste da Bahia sobre o Grupo Urucuia durante o período 1988-2011. Revista Brasileira de Cartografia, v. 66, p. 1157-1176, 2014.

PAVIANI, A.. Brasília no contexto local e regional: Urbanização e crise. Revista Território, ano VII, n. 11, 12 e 13 - set./out., Rio de Janeiro, 2003.

REZENDE, R. A.; PRADO FILHO, J.F.; SOBREIRA, F.G.; Análise temporal da flora nativa no entorno de unidades de conservação - APA Cachoeira das Andorinhas e FLOE Uaimii, Ouro Preto, MG. Revista Árvore, v. 35, p. 435-443, 2011.

ROSÁRIO, D. C.; PEREIRA, B. L.; SILVA, N. M.; GOMES, M. V. C. N.; Estudo de Impacto Ambiental na Qualidade da Água da ETA - Bolonha, Anais de Artigos (Volume II) do II Simpósio de Estudos e Pesquisas em Ciências Ambientais na Amazônia, Belém (PA), 2013.

SCHENINI, P. C.; COSTA, A. M.; CASARIN, V. W.; Unidades de Conservação: aspectos históricos e sua evolução. In: $6^{\circ}$ Congresso Brasileiro de Cadastro Técnico Multifinalitário; $4^{\circ}$ Encontro de Cadastro Técnico Multifinalitário para Países do MERCOSUL; $1^{\circ}$ Encontro de Cadastro Técnico Multifinalitário para Países da América Latina, 2004, Florianópolis. Anais do COBRAC 2004, 2004.

SILVA, L. R.; COSTA NETO, J. F.; A sustentabilidade dos recursos hídricos do Distrito Federal. In: V Congresso de Ensino, Pesquisa e Extensão e V Encontro de Iniciação Científica do UniCEUB - Educação Superior e Desenvolvimento Sustentável, 2007, Brasília. Anais do V Congresso de Ensino, Pesquisa e Extensão e V Encontro de Iniciação Científica do UniCEUB - Educação Superior e Desenvolvimento Sustentável. Brasília: UniCEUB, 2007. v. 1. p. 254-254.

SINGH, A.; Digital change detection techniques using remotely sensed data. International Journal of Remote Sensing, v. 10, n. 6, p. 989-1003, 1989.

SOUZA, C. G.; ZANELLA, L.; BOREM, R. A. T.; CARVALHO, L. M. T.; ALVES, H. M. R.; VOLPATO, M. M. L. Análise da Fragmentação da paisagem da Área de Proteção Ambiental Coqueiral, Coqueiral - MG, Ciência Florestal v. 24, p. 631-644, 2014.

SPAGNOLO, T. F. O.; GOMES, R. A. T.; CARVALHO JÚNIOR, O. A.; GUIMARÃES, R. F.; MARTINS, E. S.; COUTO JÚNIOR, A. F.; Dinâmica da expansão agrícola do município de São Desidério-BA entre os anos de 1984 a 2008, importante produtor nacional de soja, algodão e milho. Geo UERJ (2007), v. 2, p. 603-618, 2012. 


\section{CAPÍTULO 3 - ANÁLISE DA FRAGMENTAÇÃO DA PAISAGEM NA APA DO RIO SÃO BARTOLOMEU - DISTRITO FEDERAL - BRASIL (1984-2014).}

\section{RESUMO}

O objetivo deste trabalho é avaliar a fragmentação da paisagem na APA do Rio São Bartolomeu, a partir de métricas da paisagem, através dos programas Path Analyst e V-Late, com a detecção de mudança nas classes da Morphological Spatial Pattern Analysis - MSPA por meio do programa Guidos Toobox, para observar qual foi a dinâmica e efeitos da antropização na vegetação nativa da unidade de conservação. A APA do São Bartolomeu, categorizada como de uso sustentável, tem área aproximada $82.679,88 \mathrm{ha}$, em interseção com as Bacias Hidrográficas do São Bartolomeu e Preto no Distrito Federal - DF, possuindo usos urbano e rural. A deteç̧ão de mudanças utilizou a fotografia aérea de alta resolução espacial $(0,23$ m), obtido por levantamento realizado pelo Governo do Distrito Federal em 2014, e série temporal do sensor Landsat 5 TM, órbita 221 ponto 71, dos anos de 1984, 1987, 1990, 1993, 1996, 1999, 2002, 2005, 2008 e 2011, que forneceram informações sobre a ocupação da terra por vegetação natural. A análise concluiu que a pressão antrópica, ocorreu principalmente pelo interesse imobiliário, seja para uso rural ou urbano, em detrimento aos remanescentes de vegetação nativa, que perderam 15.775,83ha, que representam $18,80 \%$ do território desta área protegida, fazendo com que as manchas de vegetação nativa saíssem de 597 em 1984 para 808 em 2014. Por meio do MSPA, constatou-se que a fragmentação se deu de forma gradual e pontual, evidenciando perfurações, fenômeno que precedeu 0 desaparecimento dos fragmentos de vegetação natural. A partir de tal, sugere-se garantir a manutenção dos fragmentos que se mantiveram após os experimentos de bordas maiores, preservando a conectividade entre esses através dos corredores existentes após os mesmos experimentos.

Palavras Chaves: fragmentação da paisagem, remanescentes de vegetação nativa, APA do Rio São Bartolomeu. 


\title{
ANALYSIS OF FRAGMENTATION IN LANDSCAPE OF THE ENVIRONMENTAL PROTECTED AREA OF SÃO BARTOLOMEU RIVER - FEDERAL DISTRICT - BRAZIL (1984 - 2014)
}

\begin{abstract}
The objective of this study is to evaluate the fragmentation of the landscape in the Environmental Protected Area of São Bartolomeu River - EPASR, from landscape metrics using Path Analyst and V-Late, with change detection in classes of Morphological Spatial Pattern Analysis - MSPA through Guidos Toolbox, to observe the dynamics and effects of human disturbance on native forest in an protected area. The EPASR, categorized as sustainable use, has an area of 82.679,88ha, intersecting with the Watersheds of São Bartolomeu and Preto Rivers in the Federal District - FD, Brazil, having urban and rural uses. The change detection used a high spatial resolution aerial photography $(0.23 \mathrm{~m})$, obtained by a survey conducted by the Government of the FD in 2014, and time series of Landsat 5 TM sensor, orbit 221 point 71, the years 1984, 1987, 1990, 1993, 1996, 1999, 2002, 2005, 2008 and 2011, which provided information on the occupation of land by native forest. The analysis concluded that the anthropic pressure, occurred mainly by the real estate interest, either to rural or urban use, for the detriment of remaining native forest, which lost $15.775,83 \mathrm{ha}$, representing $18,80 \%$ of the territory, causing native forest patches came out from 597 fragments in 1984 to 808 in 2014. Through the MSPA, it was found that fragmentation occurred in a gradual and timely manner, showing perforation phenomenon that preceded the disappearance of native forest fragments. From this, it is suggested to ensure the maintenance of fragments that remained after the major edges of experiments, preserving the connectivity between them through the corridors that remains after the same experiments.
\end{abstract}

Keywords: landscape fragmentation changes, remnants of native vegetation, Environmental Protected Area of São Bartolomeu River. 


\subsection{INTRODUÇÃO}

O conceito de fragmentação refere-se às transformações da paisagem, a partir de uma condição preservada e uniforme para uma situação heterogênea e irregular, resultando em padrões fragmentados das coberturas vegetais e isolamento de habitats (BALDI et al., 2006, OLIVEIRA, 2015). As principais causas da fragmentação têm sido as atividades humanas, como a implantação de áreas urbanas, agrícolas e de infraestruturas de transporte (BUREL et al., 2004; LLAUSÀS \& NOGUÉ, 2012; OLIVEIRA et al., 2016). A fragmentação da paisagem pode aumentar a mortalidade de espécies (MAZEROLLE, 2004), atuar como barreira para a movimentação da vida silvestre (MORTELLITI et al., 2014), interferir nos níveis de polinização e dispersão de sementes (FERREIRA et al., 2013), reduzir a conectividade dos habitat (LIU et al., 2014), alterar os processos naturais dos ecossistemas (HOBBS, 1993) e reduzir a diversidade de espécies (MA et al., 2013).

O estudo da fragmentação da paisagem tem sido feito por meio da aplicação de métricas de paisagem, índices estatísticos e geoestatísticos (FORMAN \& GODRON, 1986; LINDENMAYER \& FISCHER, 2006). Oliveira et al. (2016) ao analisar a fragmentação da paisagem no Oeste da Bahia utilizaram métricas de paisagem tradicionais e aplicaram a análise dos padrões espaciais morfológicos (Morphological Spatial Pattern Analysis - MSPA). Essa metodologia permitiu a análise da fragmentação resultante das atividades agrícolas tanto em nível geral da paisagem quanto em nível de habitat.

A análise da fragmentação da paisagem pode ser de grande utilidade para a compreensão do impacto do uso e ocupação da Terra nos remanescentes de vegetação natural na APA do Rio São Bartolomeu no Distrito Federal (DF). A motivação inicial para a criação da APA do Rio São Bartolomeu se deve a previsão da construção de um reservatório para o abastecimento da população do DF. Além disso, a APA integra o bioma Cerrado, em que as taxas de desmatamento têm sido historicamente superiores às da floresta Amazônica e com menores áreas protegidas, possuindo somente $2,2 \%$ de área legalmente protegida na forma de Unidades de Conservação (KLINK \& MACHADO, 2005).

A implantação da APA do Rio São Bartolomeu não restringiu a ampliação paulatina da antropização na direção das regiões de maior fragilidade ambiental (FREITAS, 2009). Conforme previsto na Lei Federal no 9.985 de 18 de julho de 2000 (Sistema Nacional de Unidades de Conservação da Natureza) é possível coexistir a atividade humana regulada em Áreas de Proteção Ambiental. Entretanto, o 
crescimento populacional desordenado no entorno das metrópoles, aliado à ausência de políticas públicas eficientes, colaboram com o desrespeito das previsões legais.

O objetivo deste trabalho é avaliar a fragmentação da paisagem na área de estudo, a partir da aplicação de métricas tradicionais de paisagem e da Análise Morfológica dos Padrões Espaciais (Morphological Spatial Pattern Analysis - MSPA), para identificar os principais efeitos causados pela antropização na vegetação nativa nesta Unidade de Conservação.

\section{2 ÁREA DE ESTUDO}

A APA do Rio São Bartolomeu localiza-se na região centro-leste do DF a jusante da represa do Lago Paranoá e contem uma área de 82.679,88ha (Figura 3.1). Esta APA intercepta as Bacias Hidrográficas do São Bartolomeu e Preto, como também seis Regiões Administrativas do DF (Sobradinho - RA V, Planaltina - RA VI, Paranoá - RA VII, Santa Maria - RA XIII, São Sebastião - RA XIV e Lago Norte - RA $\mathrm{XVIII).} \mathrm{A} \mathrm{área} \mathrm{possui} \mathrm{usos} \mathrm{urbanos} \mathrm{e} \mathrm{rurais,} \mathrm{principalmente} \mathrm{de} \mathrm{culturas} \mathrm{de} \mathrm{ciclo} \mathrm{curto,}$ tais como a soja (Glycine max), milho (Zea mays) e sorgo (Sorghum bicolor).

O clima da região é tropical com duas estações bem distintas: uma chuvosa e quente, de outubro a abril, e outra seca e fria, de maio a setembro (CODEPLAN, 1984). O DF está localizado no Planalto Central do Brasil, onde se localizam as cabeceiras de afluentes dos três maiores rios brasileiros (Tocantins, São Francisco e Paraná) (CAMPOS, 2004). A vegetação nativa da região é o Cerrado, com suas várias formações fitofisionômicas: Campo Limpo, Campo Sujo, Cerrado, Cerradão, Mata de Galeria e Vereda (EITEN, 1993). As Matas de Galeria e Veredas estão associadas aos cursos d'água no fundo dos vales, margeando os canais de drenagens e áreas de nascentes, respectivamente (PINTO et al., 2009).

As Unidades de Conservação do DF ocupam um total de $42 \%$ de sua área física, mas muitas dessas áreas, inclusive as Áreas de Proteção Ambiental, encontram-se invadidas por edificações ilegais, o que leva a contaminação e assoreamento dos corpos d'água e consequente queda da biodiversidade (UNESCO 2002). 

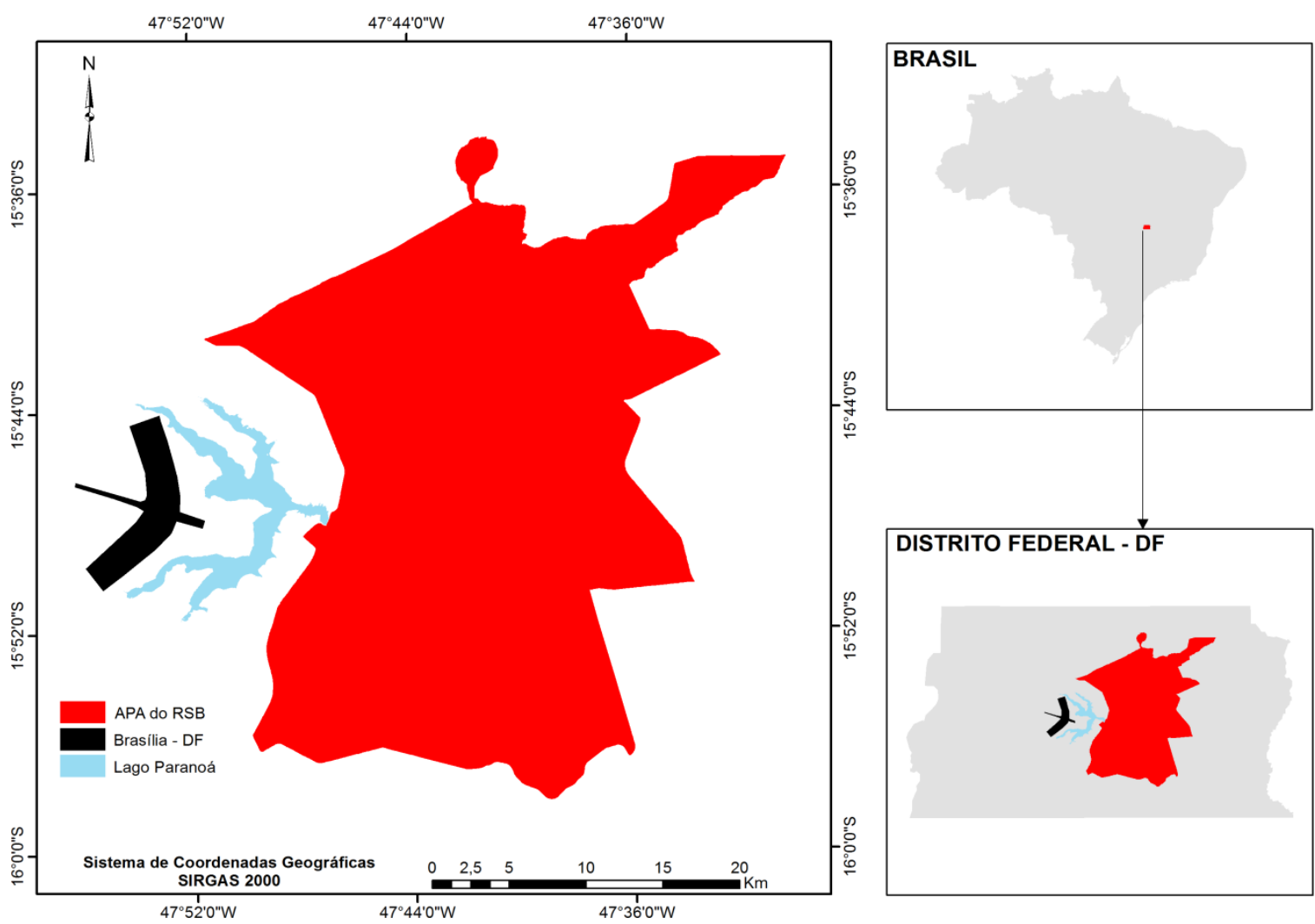

Figura 3.1 - Mapa de localização da Área de Proteção Ambiental do Rio São Bartolomeu.

\subsection{MATERIAIS E MÉTODOS}

Neste trabalho foram realizadas as seguintes etapas: (a) obtenção do uso e cobertura da Terra; (b) análise das métricas tradicionais da paisagem; e (c) análise Morfológica dos Padrões Espaciais (Morphological Spatial Pattern Analysis - MSPA).

\subsubsection{Classificação multitemporal do uso e cobertura da Terra}

O mapa de uso e cobertura da Terra foi obtido a partir da interpretação visual e vetorização em tela das fotografias aéreas de alta resolução espacial $(0,23 \mathrm{~m})$ do ano de 2014 (cedidas pelo Governo do DF) e de uma série temporal do sensor TMLandsat 5 (órbita/ponto 221/71) com intervalos de três anos (1984, 1987, 1990, 1993, 1996, 1999, 2002, 2005, 2008 e 2011). As imagens TM-Landsat selecionadas são do período seco (junho a agosto) e com pouca cobertura de nuvem $(<10 \%)$.

O método de interpretação visual e vetorização em tela foi aplicado nas fotografias aéreas e na série temporal TM-Landsat 5, usando o programa ArcGis 10.2. As classes utilizadas de uso e cobertura da Terra foram: vegetação natural, área alterada, agrossilvipastoril, urbano, água e estrada. A técnica de retroanálise foi adotada para obter uma precisa detecção de mudança. Este procedimento realiza 
uma classificação ordenada (da mais recente para a mais antiga) e aproveita os dados vetoriais existentes da interpretação do período anterior (MENKE et al., 2009; OLIVEIRA et al. 2014). Uma vez que as linhas sem mudança permanecem intactas ao longo da série histórica, minimizam-se os erros de detecção de mudança, muito comuns nas classificações automatizadas. A classe de vegetação natural da série temporal foi utilizada na análise da fragmentação da paisagem da área de estudo.

\subsubsection{Análise das métricas tradicionais de Paisagem}

As métricas tradicionais de paisagem permitem compreender quão uma área se encontra fragmentada (GUIMARÃES, 2012). Para uma análise da estrutura da paisagem usam-se métricas quantitativas de sua composição (variedade e abundância) e configuração (distribuição física ou característica espacial dos elementos) (PEREIRA et al., 2001; ANHAIA et al., 2012, SANTOS \& MACHADO, 2015). Neste trabalho, os cálculos das métricas tradicionais da paisagem foram obtidos através das ferramentas Patch Analyst 5.0 (REMPEL et al. 2012) e v-LATE 1.1 (LANG \& TIEDE, 2003), presentes no programa ArcGIS 10.2. As seguintes métricas foram extraídas: área de classe (CA), total das bordas (TE), tamanho médio das bordas (MPE), tamanho médio dos fragmentos (MPS), número de fragmentos (NumP), desvio padrão do tamanho dos fragmentos (PSSD), índice de forma média (MSI) e distância média do vizinho mais próximo (MNNDist). A análise espaciotemporal da fragmentação da APA do Rio São Bartolomeu considerou toda a série temporal TM-Landsat.

\subsubsection{Análise Morfológica do Padrão Espacial (Morphological Spatial Pattern Analysis - MSPA)}

A MSPA permite uma análise sobre os padrões espaciais e estruturais da paisagem a partir de áreas cobertas e não cobertas por floresta ou vegetação natural (Vogt et al., 2007). Uma das principais características da MSPA é a detecção automática e o mapeamento das ligações estruturais entre núcleos (OSTAPOWICZ et al. 2008). A obtenção das métricas MSPA utilizou o programa Guidos Toobox (http://forest.jrc.ec.europa.eu/download/software/guidos), que gera sete classes mutuamente exclusivas: core (núcleo), islet (ilha), loop (laço), bridge (ponte), perforation (perfuração), edge (borda) e branch (ramo) (Soille e Vogt 2009). A classificação do MSPA é feita pixel a pixel e utiliza um arquivo raster binário: 1 
(forest) e 2 (no forest). A MSPA foi aplicada na série temporal, considerando quatro larguras de borda (30m, 60m, 90m e 120m). O emprego de diferentes dimensões de bordas é para abarcar diferentes espécies da flora e da fauna local, observando os efeitos do desmatamento no bioma Cerrado em toda a sua diversidade.

\subsection{RESULTADOS}

\subsubsection{Obtenção do uso e cobertura da Terra}

A Figura 3.2 demonstra uma perda constante da vegetação natural devido ao avanço da interferência humana. Nos anos de 1980, as classes antrópicas ocupavam áreas inferiores que 50\%, atualmente as atividades antrópicas têm índices similares à cobertura natural. No entanto, constata-se que não há uma tendência de crescimento das atividades agrossilvipastoris, que passa de 21.996,20ha (1984) para 21.359,85 ha (2014). Este fato desperta atenção, pois a expansão agrícola é a principal causa de perda de vegetação natural no bioma Cerrado, fenômeno não constatado na área de estudo.

As áreas alteradas cresceram 58,84\% durante o período estudado, essa classe representa os espaços que não agregam as características das demais classes levantadas pelo trabalho. O crescimento das áreas alteradas em substituição aos remanescentes nativos sugere uma motivação imobiliária e o abandono de áreas agrícolas que não promove uma regeneração imediata da vegetação natural. Os parcelamentos do solo em áreas rurais no entorno das regiões economicamente valorizadas de Brasília (DF) consistem em uma desvirtuação dos imóveis rurais, que tornam moradias e infraestruturas de lazer com tamanho médio de 2,00 ha.

A Figura 3.2 demonstra o aumento do uso urbano em dez vezes entre 1984 e 2014, evidenciando a ação de especuladores imobiliários (PAVIANI, 2003). complexo cenário fundiário do DF impacta diretamente o uso e cobertura da Terra na APA analisada, pois o avanço das ocupações desordenadas sobre áreas sensíveis ambientalmente tem sido a principal causa de pressão sobre os remanescentes nativos. 


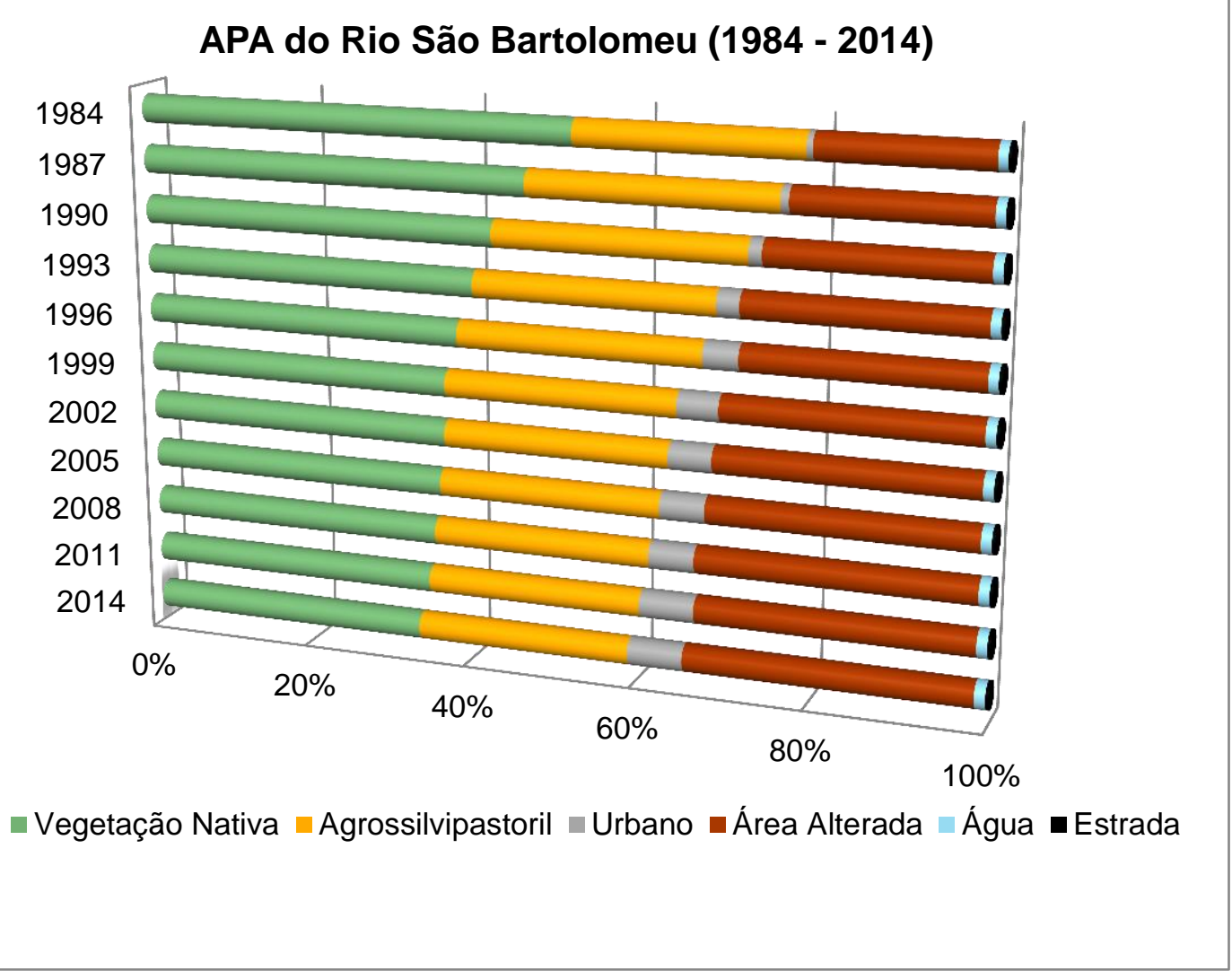

Figura 3.2 - Dinâmica das mudanças da cobertura da terra na APA do Rio São Bartolomeu.

\subsubsection{Métricas tradicionais da paisagem}

A Figura 3.3 demonstra os resultados das métricas tradicionais de paisagem. No período estudado, a área da classe vegetação natural (CA) teve redução de 15.775,83ha, passando de 43.908,60ha (1984) para 28.132,77ha (2014). A extensão total das bordas (TE) apresenta uma oscilação ao longo do período analisado, com 2.200 km (1984), 2.450 km (1999) e 2.500 km (2011). O tamanho médio das bordas (MPE) teve pequena oscilação e manteve uma tendência de queda de 3,8 km (1984) para 3,0 km (2014). Este parâmetro reflete o tamanho dos fragmentos, pois quanto menor a borda, menor a área do fragmento. Em consonância com a MPE, o tamanho médio dos fragmentos (MPS) teve um decréscimo significativo ao longo dos anos, caindo de 75 ha (1984) para 35 ha (2014).

O número de fragmentos (NumP) evidencia a fragmentação da paisagem com aumento constante, onde ambiente inicial em 1984 com 600 fragmentos, intensificação da fragmentação alcançando 800 fragmentos a partir de 2002. Tais resultados são acompanhados pelo desvio padrão do tamanho dos fragmentos (PSSD), que evidencia a intensidade da antropização no terreno, regredindo de cerca de 350ha (1984) para 150ha (2014). 
a) $\mathrm{CA}$

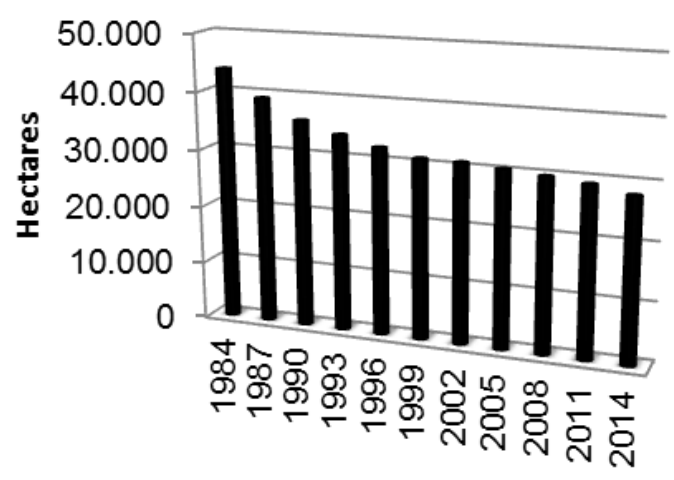

c) MPE

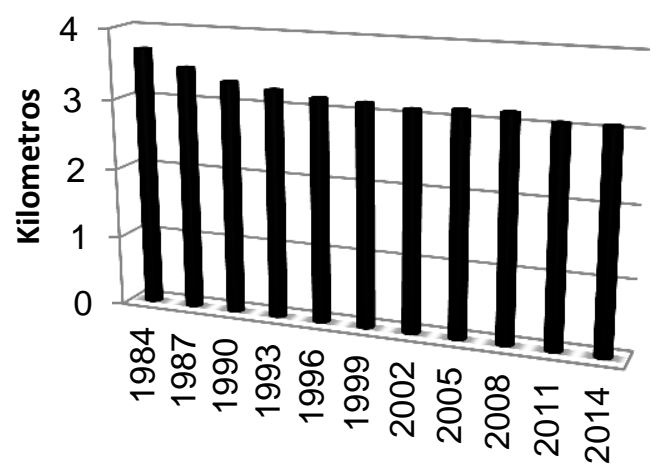

e) NumP

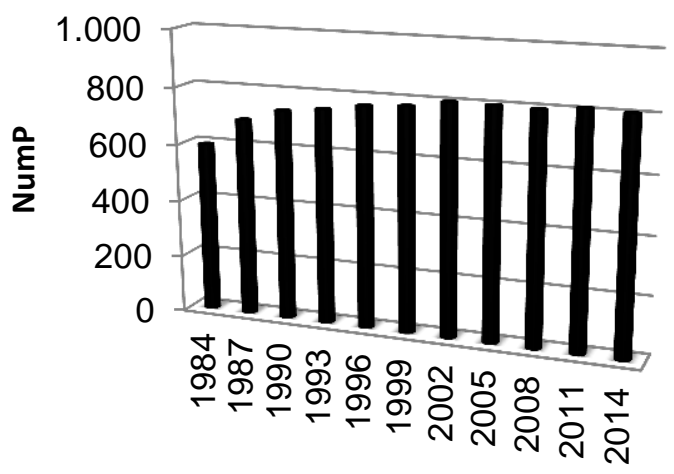

g) MSI

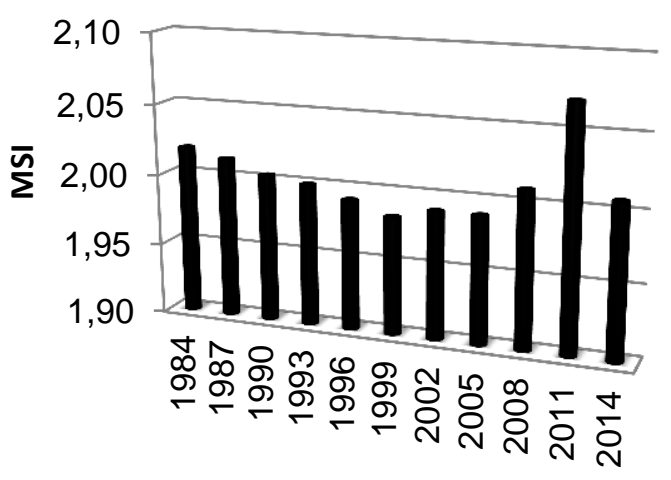

b) TE

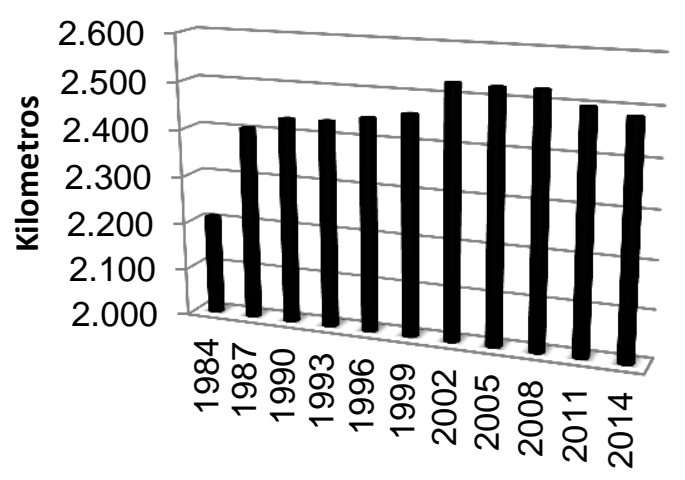

d) MPS

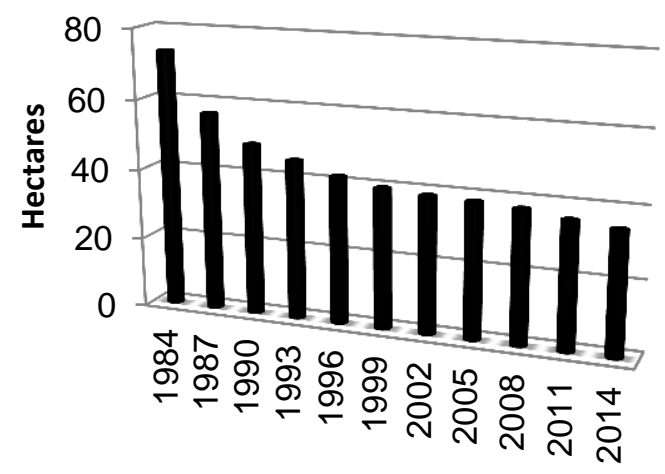

f) PSSD

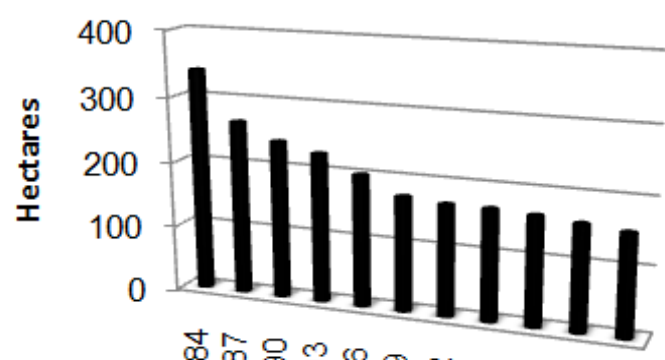

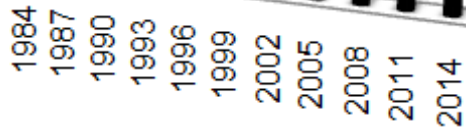

h) MNNDist

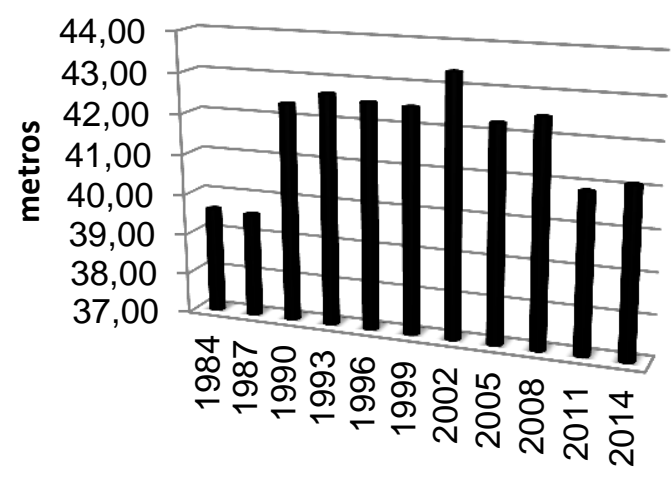

Figura 3.3 - Métricas tradicionais da área de estudo no período de 1984 à 2014: (a) CA, (b) TE, (c) MPE, (d) MPS, (e) NumP, (f) PSSD, (g) MSI e (h) MNNDist . 
Por sua vez, o índice de forma média (MSI) alcançou 2,0 em 1984, sofrendo uma queda contínua até 1999, voltando a crescer em 2002, em comportamento que se manteve até 2011, observando uma nova queda em 2014. Enquanto a distância média do vizinho mais próximo (MNNDist) oscilou durante o período entre $39 \mathrm{~m}$ à $43 \mathrm{~m}$.

\subsubsection{Análise Morfológica do Padrão Espacial (MSPA)}

As classes MSPA ao longo do período estudado retrata a evolução da fragmentação na área de estudo devido às ações antrópicas (Figuras 3.4, 3.5, 3.6 e 3.7). Em 1984, a APA do Rio São Bartolomeu apresenta as seguintes áreas de núcleo (core) conforme as diferentes dimensões de borda: 47,14\% (30m), 42,36\% (60m), 39,42\% (90m) e 36,89\% (120m). Em 2014, esses valores apresentam um significativo decréscimo: $27,11 \%(30 \mathrm{~m}), 21,80 \%(60 \mathrm{~m}), 18,80 \%(90 \mathrm{~m})$ e $16,44 \%$ (120m) (Figura 3.4). Portanto, a classe de núcleo apresenta uma diminuição de área ao longo dos anos, enquanto a quantidade de núcleos aumenta no período devido à fragmentação (Figuras 3.6 e 3.7). Ainda referente à frequência, observa-se na Figura 3.7 (a) que quanto menor a borda utilizada no experimento, maior a diferença entre os anos, pois na utilização de bordas maiores, alguns núcleos encontrados nos experimentos de menores bordas desaparecem, ficando apenas os núcleos maiores.

Outro parâmetro que permite constatar a intensidade da ação humana na unidade de conservação é à formação de ilhas (islets), que são fragmentos sem conectores, prejudicando a função ambiental do remanescente de vegetação nativa. Neste caso, ao observar a percentagem de área coberta por esta classe através da Figura 3.6 (b), observa-se uma disparidade entre os anos, pois quanto maior a borda utilizada no experimento, maior a quantidade de ilhas existentes no terreno.

O índice de borda (edge) apresenta variações, que depende muito do tamanho dos fragmentos, quanto menor o fragmento menor a extensão da borda, contudo, a depender da quantidade de áreas núcleo, é possível resultar num índice de borda mais elevado. As Figuras 3.6 (c) e 3.7 (c) demonstram um padrão com avanço gradual ao decorrer dos anos, por consequência da intensa antropização evidenciada na área de estudo. 

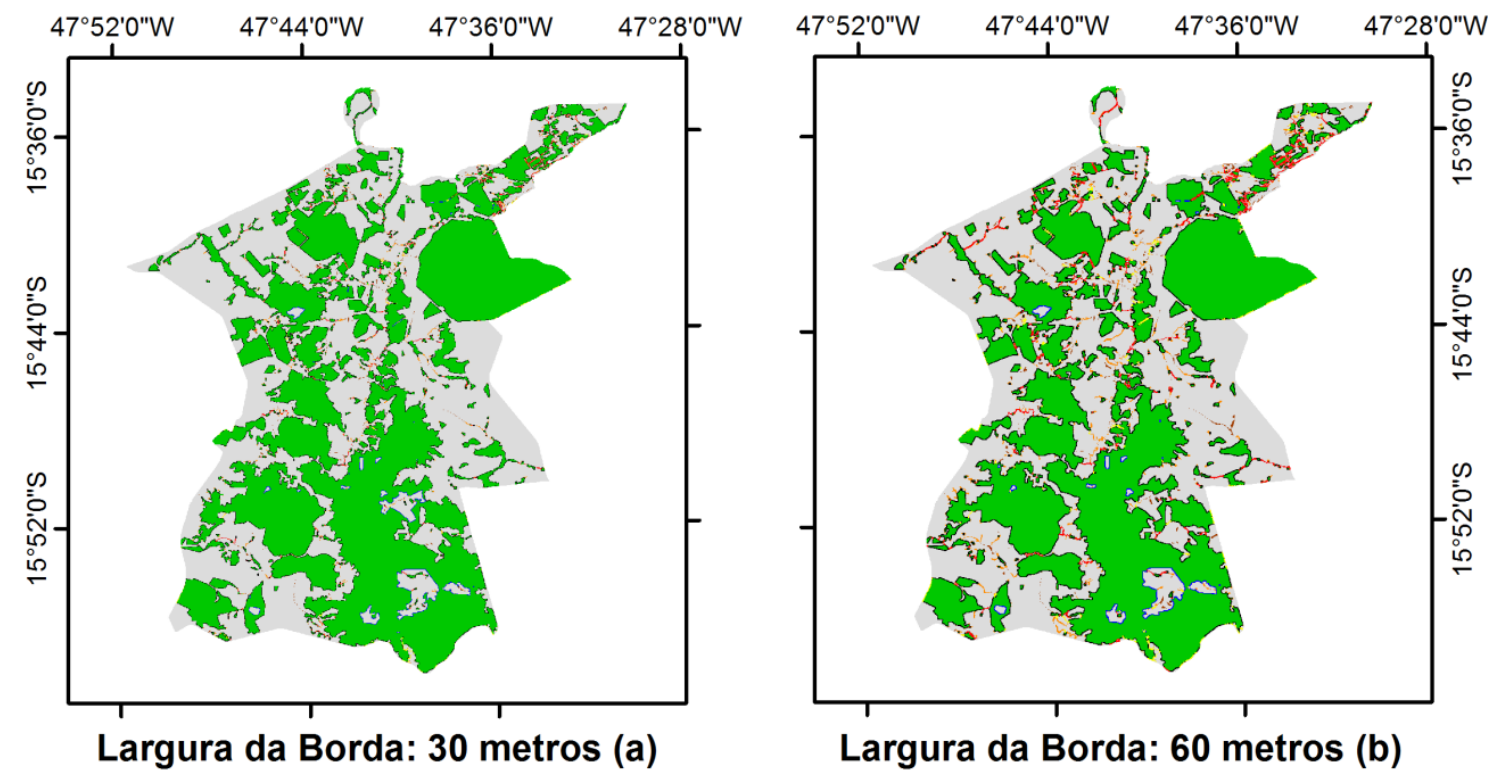

Largura da Borda: 60 metros (b)
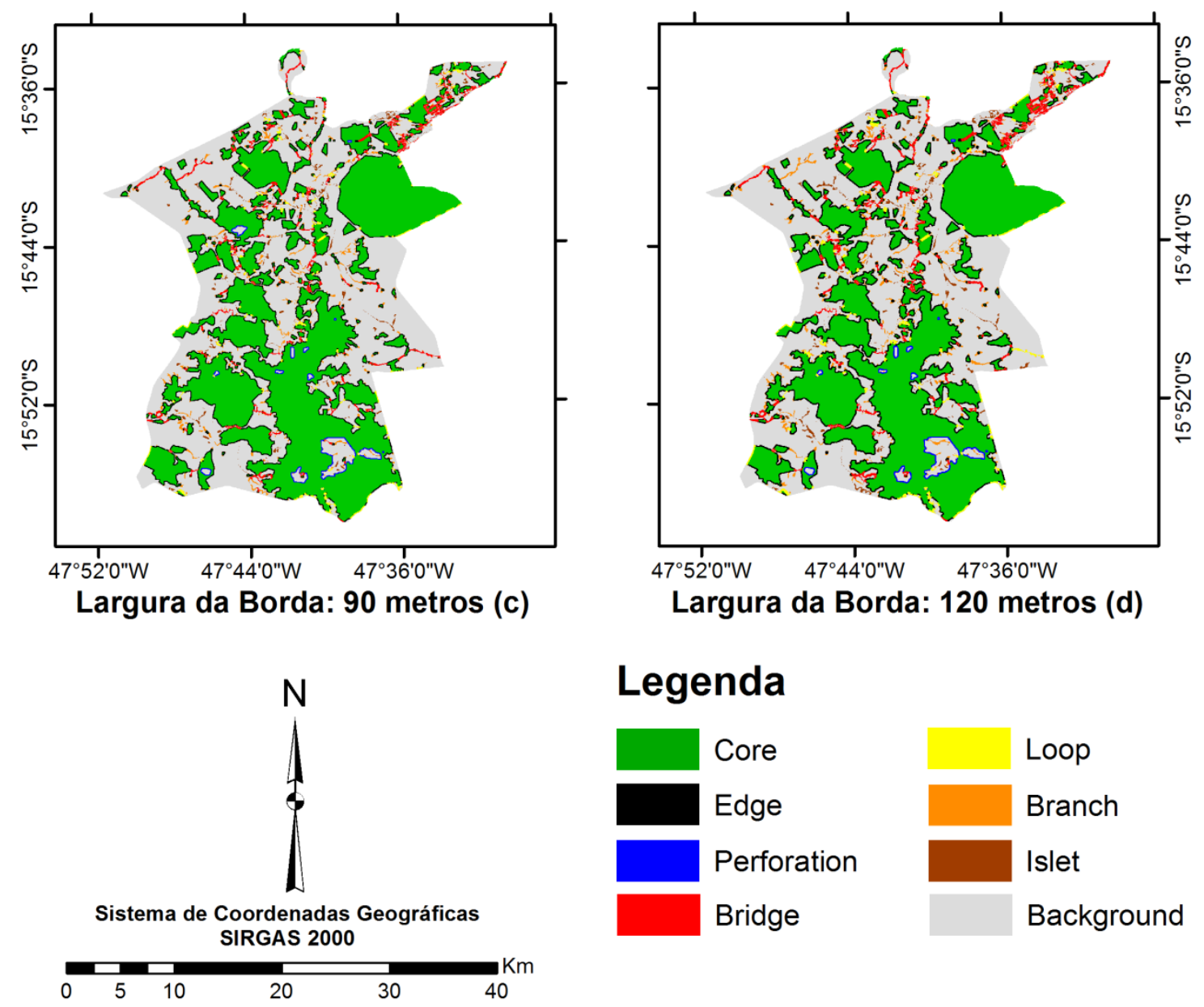

\section{Legenda}

\begin{tabular}{|l|l|}
\hline Core & Loop \\
\hline Edge & Branch \\
\hline Perforation & Islet \\
\hline Bridge & Background \\
\hline
\end{tabular}

Figura 3.4 - MSPA da vegetação natural existente em 1984, com bordas de (a) 30m, (b) 60m, (c) $90 \mathrm{~m}$ e (d) $120 \mathrm{~m}$. 

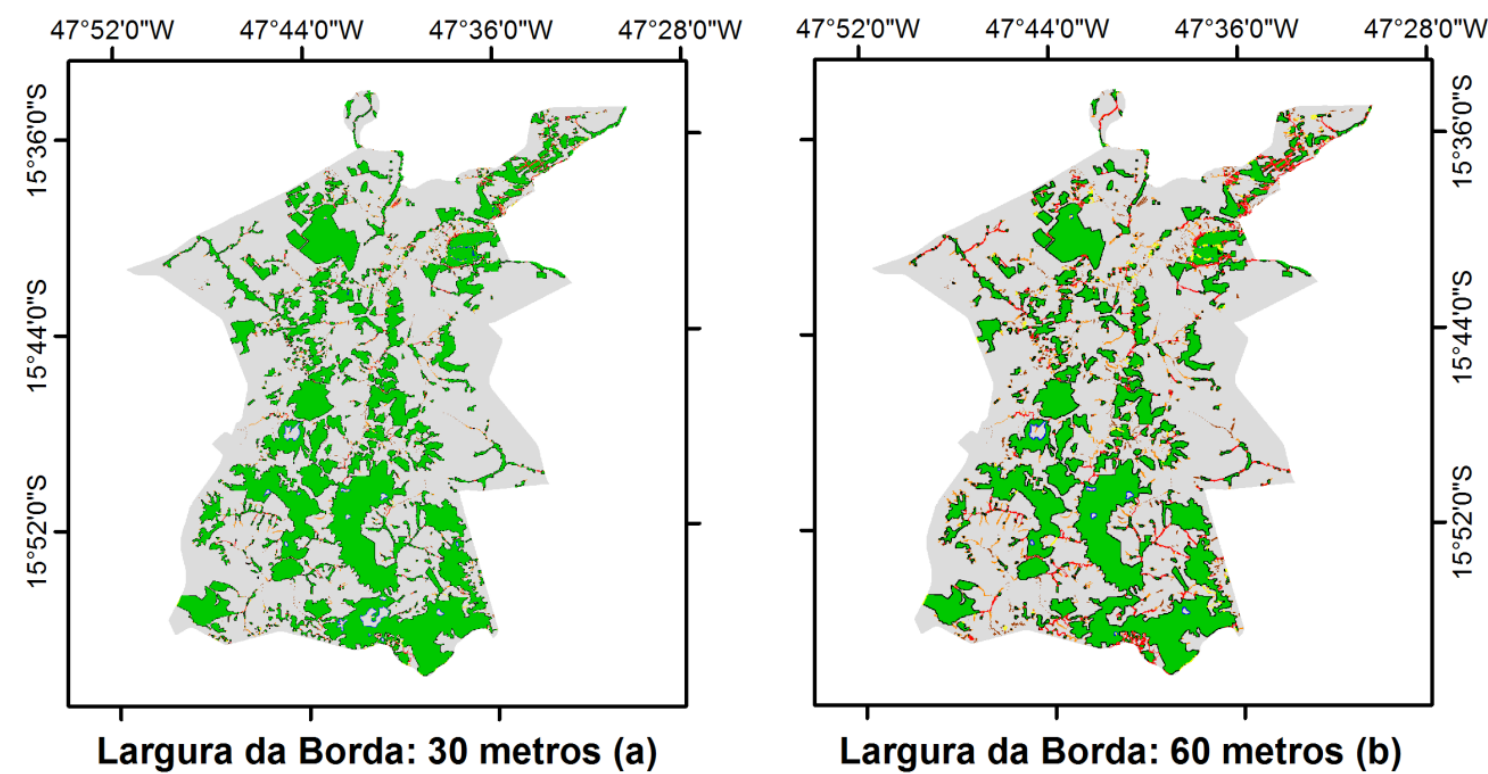

Largura da Borda: 60 metros (b)
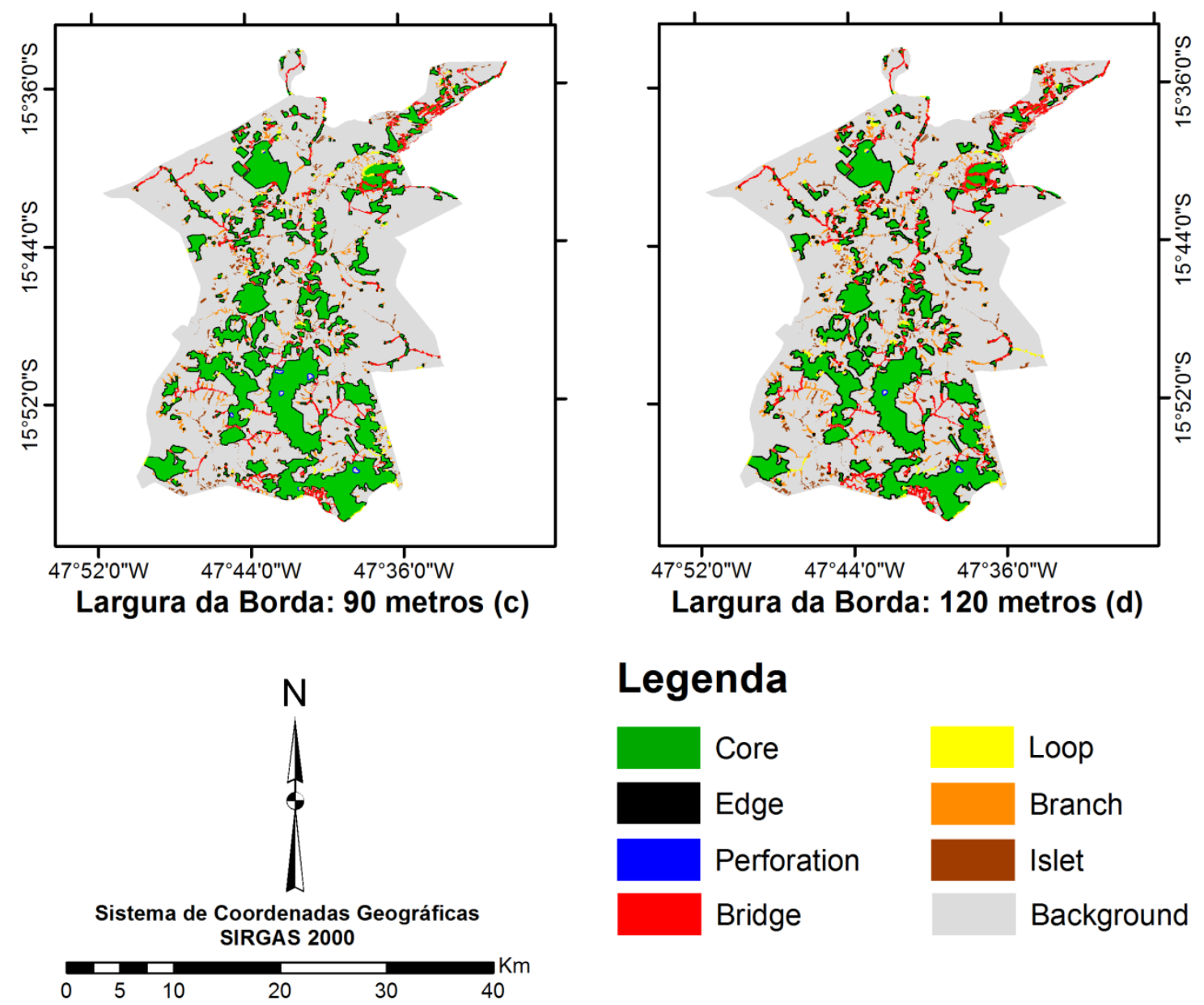

\section{Legenda}

\begin{tabular}{|l|l|}
\hline Core & Loop \\
\hline Edge & Branch \\
\hline Perforation & Islet \\
\hline Bridge & Background \\
\hline
\end{tabular}

Figura 3.5 - MSPA da vegetação natural existente em 2014, com bordas de (a) 30m, (b) 60m, (c) $90 \mathrm{~m}$ e (d) $120 \mathrm{~m}$. 
a)

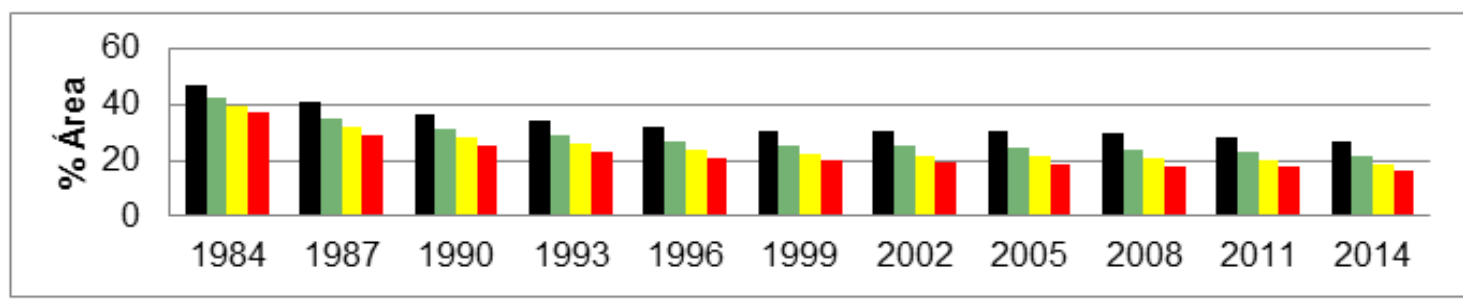

b)

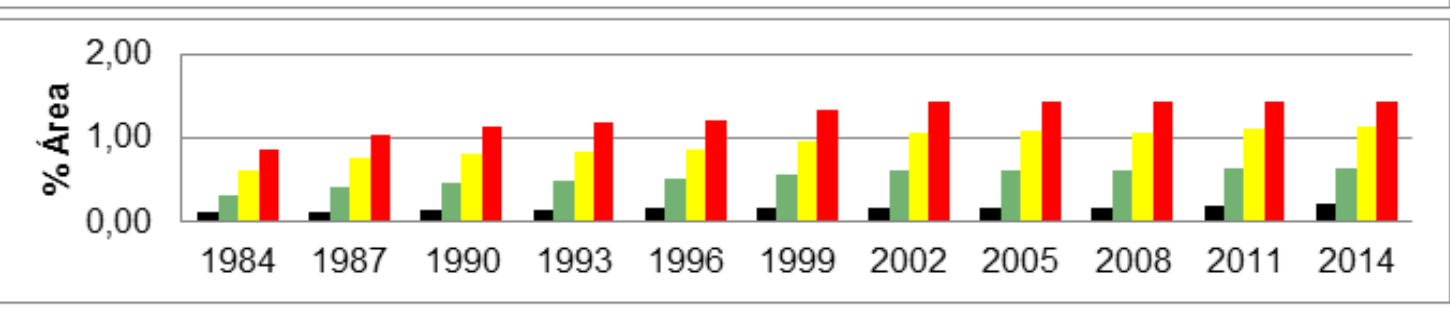

c)

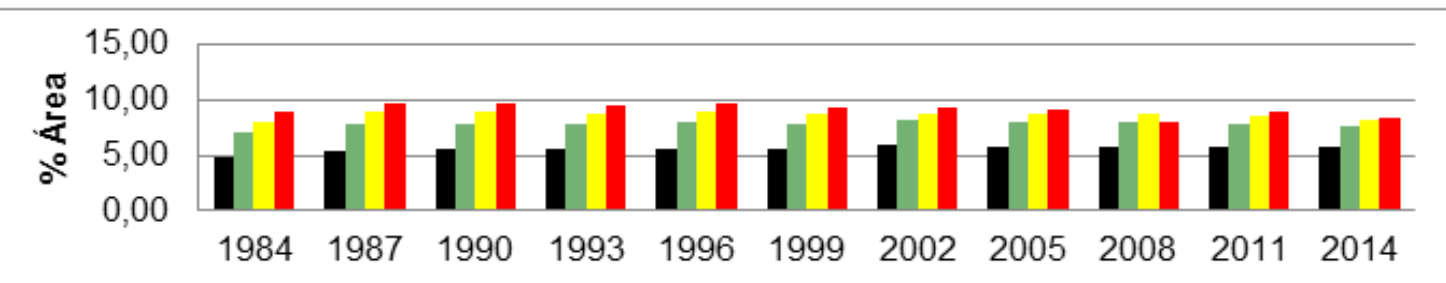

d)

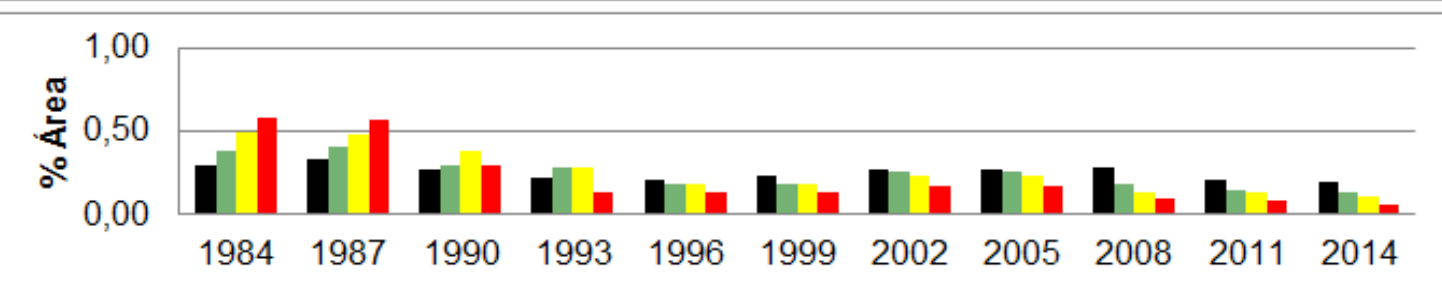

e)

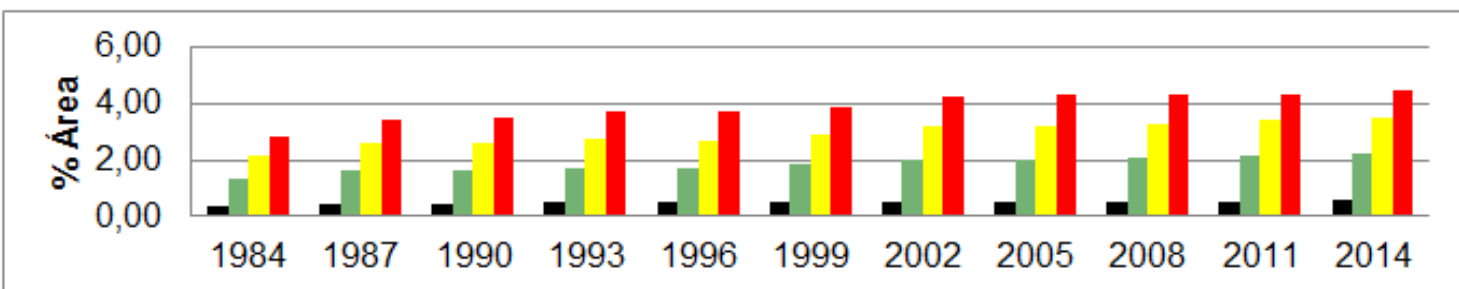

f)

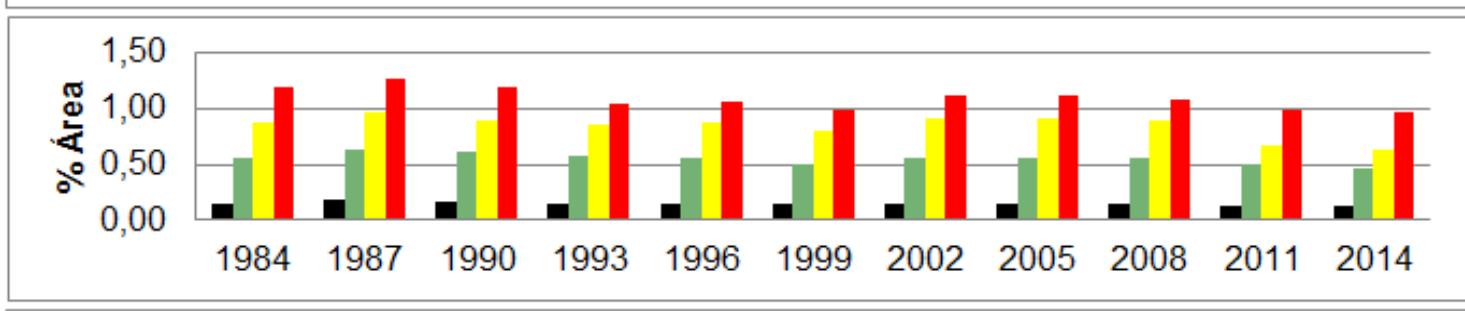

g)

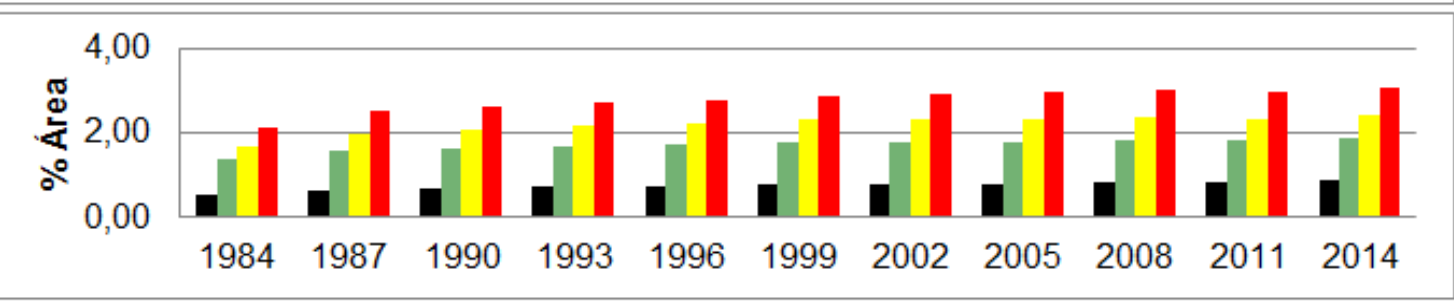

\section{Legenda}

Bordas: $\square 30 \mathrm{~m} \quad 60 \mathrm{~m} \quad 90 \mathrm{~m} \quad 120 \mathrm{~m}$

Figura 3.6 - MSPA em percentagem da área de estudo no período de 1984 à 2014: (a) Core, (b) Islet, (c) Edge, (d) Perforation, (e) Bridge, (f) Loop e (g) Branch. 
a)

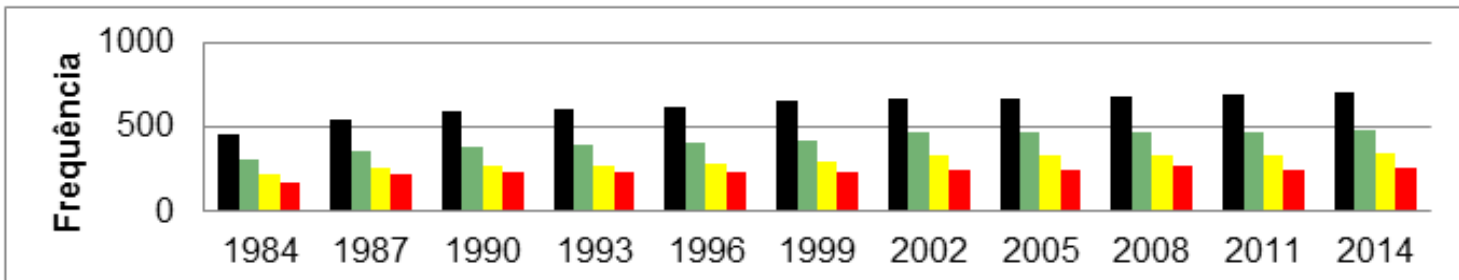

b)

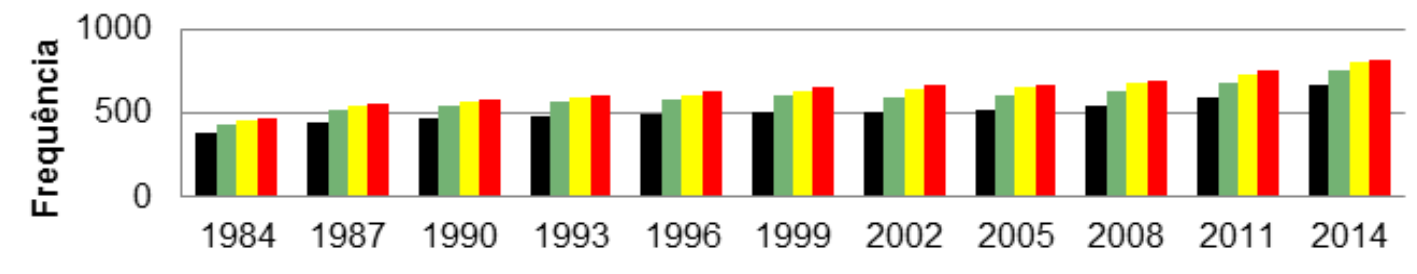

c)

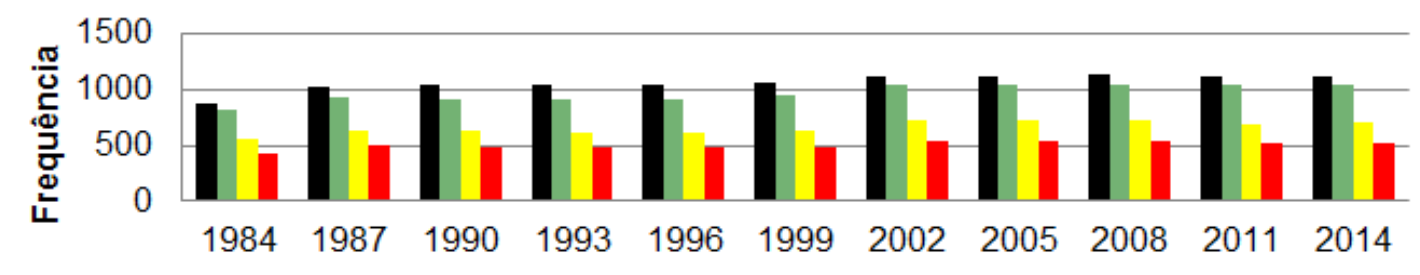

d)

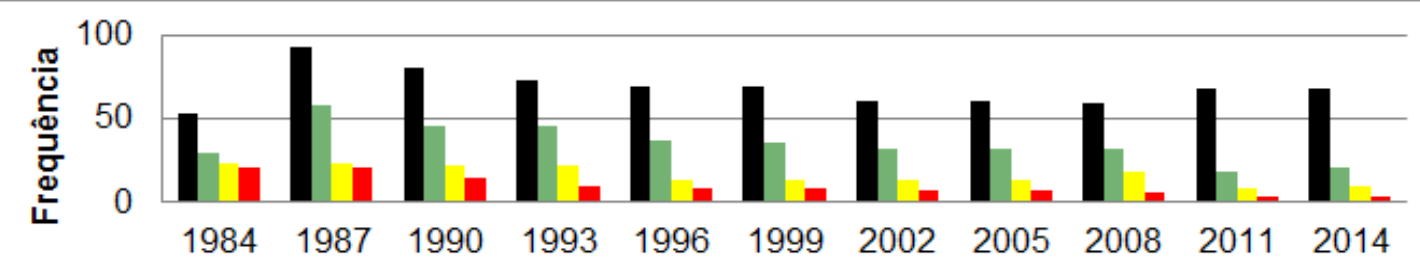

e)

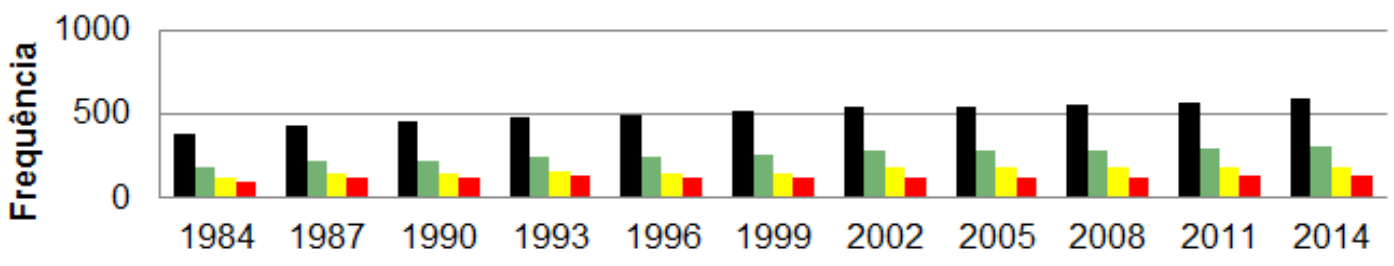

f)

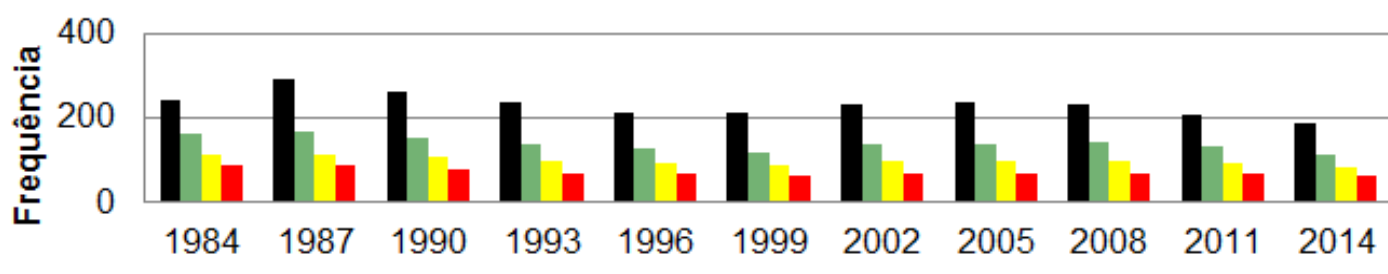

g)

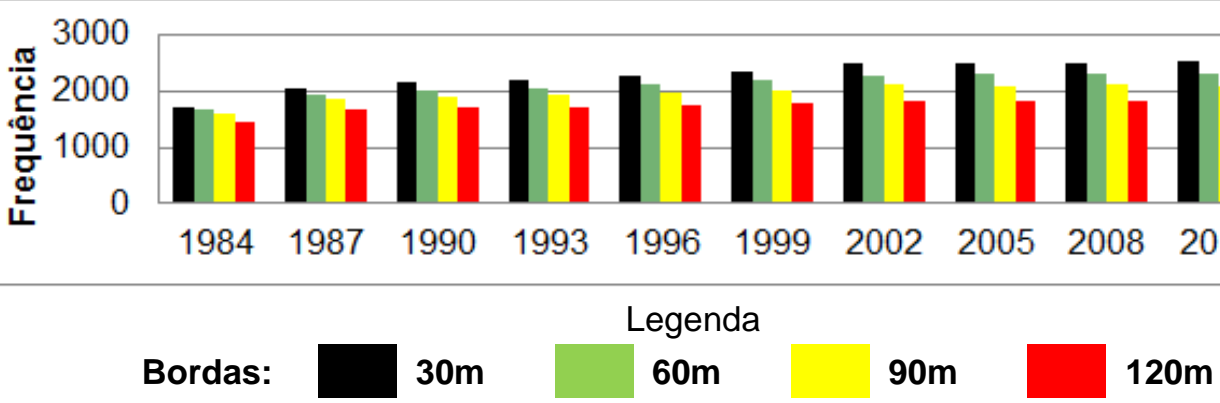

Figura 3.7 - MSPA em frequência no período de 1984 à 2014: (a) Core, (b) Islet, (c) Edge, (d) Perforation, (e) Bridge, (f) Loop e (g) Branch. 
Apesar de ocuparem menos que $1 \%$ da área, as perfurações (perforations) permitem constatar como e quando ocorreu com maior intensidade o processo de fragmentação, pois precede o desaparecimento da vegetação nativa de uma área. No período 1984-1990 tal métrica ocorre com maior intensidade devido o avanço sobre a vegetação nativa na unidade de conservação (Figura 3.6 (d) e 3.7 (d)), seguindo um padrão nos anos subsequentes.

Outra consequência da fragmentação são os corredores (bridge), que tem aproximadamente 500 ocorrências a cada ano estudado, ocupando na maioria dos anos área menor que $5 \%$ da área estudada. Tal índice depõe sobre as conectividades existentes em cada experimento realizado com as bordas de $30 \mathrm{~m}$, $60 \mathrm{~m}, 90 \mathrm{~m}$ e 120 , sendo um elemento importante na manutenção da função ambiental dos fragmentos. Os resultados constantes das Figuras 3.6 (e) e 3.7 (e) nos mostram que tal classe ocupa mais área com uma maior borda $(120 \mathrm{~m})$, porém, é mais frequente nos experimento realizado com menor borda $(30 \mathrm{~m})$, o que esta diretamente relacionada à quantidade de fragmentos mais presentes no experimento de menor borda.

O Art. 14 da Lei Federal 12.651/2012 indica que a localização das reservas legais deva favorecer a formação de corredores ecológicos. Neste tocante, a MSPA salienta os corredores ecológicos (bridge), sendo capaz de auxiliar os detentores de imóveis rurais e poder público na escolha das áreas de reserva legal.

As conexões de extremidades na mesma área núcleo (loops) estão diretamente relacionadas com o processo de perfuração da vegetação, sinalizando a intensidade do processo de fragmentação. No entanto, em se tratando de porcentagem de área ocupada, verifica-se que quanto maior a borda do experimento, maior a área ocupada (Figura 3.6 (f)), o que não é traduzido pela freqüência, que diminui com o aumento da borda experimentada (Figura 3.7 (f)).

Por fim, as conexões com apenas uma extremidade do "loop", "bridge", "perfuration" ou "edge" (branchs) expressam a perda de conectividade entre os fragmentos, pois são corredores (bridges) que perdem o seguimento, afetando diretamente na função ambiental dos fragmentos remanescentes de uma paisagem. Através das Figuras 3.6 (g) e 3.7 (g), também detectamos que quanto maior a borda experimentada, maior a área ocupada por essa classe, por outro lado, quanto menor a borda, maior a frequência desta na área de estudo. 


\subsection{DISCUSSÃO}

\subsubsection{Métricas Tradicionais}

Observando os resultados das métricas tradicionais, em comparação a outros trabalhos acadêmicos, constatou-se que Oliveira (2015) detectou que na região oeste da Bahia, entre 1988 à 2011, 26,57\% do território perdeu vegetação natural, enquanto que na APA do Rio São Bartolomeu, entre 1987 à 2011, 11,87\% da área deixou de ser coberta por vegetação natural. Os índices mostram uma diferença considerável entre os trabalhos, contudo, vale destacar que no oeste baiano, o período analisado recepcionou a época de maior expansão agrícola da região, entre 1990 e 2000 (SAMPAIO, 2012), no entanto, no mesmo período a APA do Rio São Bartolomeu, que é uma área protegida apresentou perda significativa sem nenhum fenômeno conhecido como no oeste baiano.

As áreas ocupadas pelos remanescentes nativos estão distribuídas em fragmentos no perímetro objeto de estudo, as métricas referentes a densidade e tamanho destas manchas refletem a intensidade da ação humana no espaço. $\mathrm{Na}$ APA do Rio São Bartolomeu, durante os trinta anos foi observado o crescimento desta métrica, que oscilou entre 597 (1984) e 808 (2014), com uma média de 780 em uma área de 84 mil hectares, diferente do encontrado por Lucas (2011) que em uma área de 36 mil hectares do munícipio de São Gonçalo do Rio Abaixo - MG, registrou 2.113 fragmentos de vegetação nativa. A diferença nesses estudos é explicada frente aos dados do tamanho médio destes fragmentos, onde na APA variou entre 341,04ha (1984) e 153,76ha (2014), resultando em uma média de 200,40ha, enquanto Lucas (2011) constatou uma média dos fragmentos florestais em área de 11,11ha.

Faz parte da análise os estudos referentes as bordas dos fragmentos, que expressam a intensidade do processo de fragmentação e potencialidade da função ambiental de uma mancha, assim como tendência ao desaparecimento. No presente o tamanho médio das bordas oscilaram entre 3,70km (1984) à 3,08km (2014), resultado superior aos 991,95m encontrados por Silva \& Souza (2014) na Floresta Nacional (FLONA) de Ibura no estado do Sergipe, com área aproximada de 114 mil hectares.

Segundo o Sistema Nacional de Unidades de Conservação (SNUC), as Florestas Nacionais são áreas com cobertura florestal de espécies predominantemente nativas e tem como objetivo básico o uso múltiplo sustentável 
dos recursos florestais e a pesquisa científica, permitindo apenas a manutenção das populações tradicionais que já habitavam a unidade quando de sua criação. Portanto, a Flona é uma unidade de conservação que tem regime de uso mais restrito que a APA, porém, considerando o tamanho médio das bordas, os resultados apontam uma condição mais favorável na APA.

Em relação ao índice médio das formas (MSI) dos fragmentos, os resultados da APA do Rio São Bartolomeu apresentaram variações, entre 1,98 e 2,07, intervalo que recepciona o valor encontrado por Silva \& Souza (2014) na Flona de lbura, que foi de 2,0, porém diferente de Oliveira (2015), onde os anos analisados apresentaram um padrão em torno de 1,60.

Frente aos dados da média do vizinho mais próximo (MNNDist), constatamos que os dados entre o presente trabalho que oscilou entre 38,9m e 43,36m, são similares ao encontrado por Lucas (2011) no munícipio de São Gonçalo do Rio Abaixo - MG, que foi de 44,30m entre as manchas florestais.

\subsubsection{Análise Morfológica do Padrão Espacial (MSPA)}

Com a execução da MSPA, foi possível melhor entender a ação antrópica na APA do Rio São Bartolomeu, através do software Guidos Toobox, com experimentos que utilizaram bordas de 30m (1), 60m (2), 90m (3) e 120m (4). Sobre as áreas núcleo (CORE), no presente estudo, foi constatada uma perda significativa de vegetação nativa nos experimentos, partindo de 47\% em 1984 e chegando a 27\% em 2014, com 30m de borda, perda similar ao encontrado por Sun \& Southworth (2013) no estado do Acre em intervalo menor, saindo de 95\% em 1986 e chegando a $74 \%$ em 2010.

Tanto a APA do Rio São Bartolomeu quanto o estado do Acre, não são áreas destinadas a agricultura intensiva, ainda que existam ocorrências desta atividade, assim como a área de estudo explorada por Elbakidze et al. (2016) em região florestal da Lituânia no ano de 2014, onde com um efeito de borda de 50m a área núcleo (CORE) atingiu 70\%. Diferente do oeste baiano, que tem uma vocação agrícola, assim, o experimento de Oliveira (2015) registrou em 1988 uma área acima de $80 \%$ em área núcleo, que caiu para $60 \%$ em 2011, perda similar a encontrada nas outras regiões, mesmo com diferente vocação de uso do solo.

Referente a formação de ilhas (islets) nos experimentos, na área de estudo, observou-se um comportamento padrão, ocupando no máximo 1,5\% do território durante o período estudado, diferente do constatado por Sun \& Southworth (2013), 
que teve um pico de 0,3\% no estado do Acre e Oliveira (2015), que registrou maior marca em $0,18 \%$. Tais informações apontam que as supressões de vegetação ocorridas no Acre e no oeste baiano são ordenadas e em blocos, diferente do percebido na APA do Rio São Bartolomeu, que sugere uma ocupação gradual e pontual. No entanto, ao observarmos o estudo de Saura et al. (2011) em Boyal na Espanha, registrou-se uma presença de 0,91\% desta classe na região de estudo, algo intermediário entre os encontrados por Sun \& Southworth (2013), Oliveira (2015) e o presente trabalho, sugerindo assim uma diversidade na dinâmica de ocupação antrópica sobre os espaços ocupados por florestas.

$\mathrm{Na}$ classe que reporta sobre a ocupação das bordas (edges) na paisagem, na unidade de conservação avaliada, foi uma tendência aumentar a ocupação destas a cada faixa experimentada, padrão também percebido por Sun \& Southworth (2013) e Oliveira (2015).

Observando as perfurações (perforations), constatou-se que a classe precede o desaparecimento de fragmentos, logo, aparecem com maior frequência no período de maior ação humana em detrimento a vegetação natural, como nos períodos de 1984 à 1990 na Figura 3.7 (d). No estudo de Oliveira (2015), a percepção de padrão no desmatamento também se confirma nesta classe, o que ocorre parcialmente em Sun \& Southworth (2013), exceto pelos dados de 1991.

A classe Bridge manifesta-se sobre a formação de corredores no espaço estudado, possibilitando especular o grau de ameaça às funções ambientais dos fragmentos. Neste, foi identificado que quanto maior a fragmentação maior será a formação de corredores, padrão que também foi identificado no oeste da Bahia através de Oliveira (2015) e Saura et al. (2011) na Espanha, tanto nas regiões da Segovia e Boyal.

Em relação a classe Loop, que são as conectividades dentro de uma mesma perfuração, os experimentos da APA mostram um padrão, em cenário similar ao percebido em 1991 por Sun \& Southworth (2013), mas não observado por Oliveira (2015), por conta da forma que se deu a antropização nas diferentes regiões, que na APA e no Acre ocorreram de forma gradual e isolada, diferente do Oeste baiano.

A variação encontrada no presente estudo acompanha o que foi anotado por Elbakidze et al. (2016) na Lituânia, com a ocupação desta classe se aproximando no máximo a 1,5\%, mantendo a tendência de crescimento a partir do aumento da borda adotada pelo experimento. 
Para a classe Branch que mostra os corredores interrompidos, o que agrava a potencialidade em manter a função ambiental nos fragmentos, os resultados de Sun \& Southworth (2013) e Oliveira (2015) são similares aos encontrados na APA do Rio São Bartolomeu, mostrando que quanto maior a fragmentação, maior será a frequência desta classe.

\subsection{CONCLUSÃO}

A APA do Rio São Bartolomeu, uma das primeiras unidades de conservação criada no Brasil, sofreu durante os primeiros trinta anos de existência com a pressão antrópica, principalmente pelo interesse imobiliário, seja para uso rural ou urbano, em detrimento aos remanescentes de vegetação nativa, que perderam 15.775,83ha, que representam $18,80 \%$ do território desta área protegida. $O$ presente trabalho permitiu compreender como se deu o processo de fragmentação da paisagem, que fez as manchas de vegetação nativa saíssem de 597 em 1984 para 808 em 2014.

Por consequência desta fragmentação causada pela ação humana, houve diminuição no tamanho dos fragmentos e aumento das bordas, que compõe a região de maior fragilidade de um fragmento. As métricas tradicionais nos permitiram a leitura de quão intenso ocorreu o processo de desconstrução da paisagem pela ação antrópica em detrimento a vegetação natural.

Por meio do MSPA, foi também possível constatar que a fragmentação se deu de forma gradual e pontual, aumentando as perfurações principalmente pelo avanço da atividade imobiliária na área. Fenômeno que precedeu o desaparecimento dos fragmentos de vegetação natural. Assim como observou a manutenção de corredores mesmo nos cenários mais fragmentados, com maior efeito de borda, desta forma, para a garantia da proteção do espaço é necessário que o poder público utilize destas informações para planejar uma estratégia de proteção, observando os corredores mais frágeis, que desaparecem com os experimentos com bordas de 30 metros e os mais resistentes, que suportam a um impacto de 120 metros na borda. A partir de tal, sugere-se garantir a manutenção dos fragmentos que se mantém após os experimentos de bordas maiores, preservando a conectividade entre esses através dos corredores existentes após os mesmos experimentos. 


\section{REFERÊNCIAS}

ANHAIA, T. R. S.; LUIZ, A. M. E. ; LEITAO, K. ; MORO, R. S. . A paisagem do Rio Pitangui em seu curso superior, no $1^{\circ}$ Planalto Paranaense. Ra'e ga (UFPR), v. 24, p. 134-148, 2012.

BALDI, G.; GUERSCHMAN, J. P.; PARUELO, J. M.; Characterizing fragmentation in temperate South America grasslands. Agriculture; Ecosystems and Environment; v. 116, p. 197-208; 2006.

BARBOSA, R.I.; CAMPOS, C.; Detection and geographical distribution of clearing areas in the savannas ('lavrado') of Roraima using Google Earth web tool; Journal of Geography and Regional Planning; 2011.

BRASIL; Decreto 88.940, de 07 de novembro de 1983; Criação das Áreas de Proteção Ambiental do Rio São Bartolomeu e do Rio Descoberto.

BRASIL; Lei 9.985, de 18 de julho de 2000; Sistema Nacional de Unidades de Conservação - SNUC.

BRASIL; Lei 12.651, de 25 de maio de 2012; Lei de proteção da vegetação nativa.

BUREL, F.; BAUDRY, J.; Landscape ecology: concepts, methods, and applications. Enfield, N.H.; Science Publishers. V. XVI, 362 p; 2004.

CAMPOS, J. E. G.; Hidrogeologia do Distrito Federal: Bases para a gestão dos recursos hídricos subterrâneos; Revista Brasileira de Geociências; São Paulo SP; v. 34, n. 1, p. 41 - 48; 2004.

CODEPLAN; Atlas do Distrito Federal; Governo do Distrito Federal - GDF; Brasília - DF; 1984.

EITEN, G.; Vegetação; In: NOVAES PINTO, M (org); Cerrado: caracterização, ocupação e perspectivas; 2. ed., Brasília: Edunb/Sematec; Brasília - DF; 1993.

ELBAKIDZE, M; RAZAUSKAIT, R; MANTON, M; ANGELSTAM, P; MOZGERIS, G; BRUMELIS, G; BRAZAITIS, G; VOGT, P; The role of forest certification for biodiversity conservation: Lithuania as a case study; Eur J Forest Res; 2016.

FERREIRA, P. A.; BOSCOLO, D.; VIANA, B. F.; What do we know about the effects of landscape changes on plant-pollinator interaction networks?; Ecological Indicators; v. 31; p. 35-40; 2013.

FREITAS, C. F. S.; Proteção Ambiental e Direito à Cidade no processo de expansão urbana do Distrito Federal: até que ponto existe um conflito?; Tese de Doutorado Universidade de Brasília - UnB; Brasília-DF, 2009.

FORMAN, R. T. T.; GODRON, M; Landscape ecology. New York: Wiley \& Sons Ed.; 619p; 1986. 
GUIMARÃES, B. P.; Análise multitemporal do uso e ocupação do solo no município de Baianópolis (BA); Dissertação de Mestrado - Universidade de Brasília - UnB; 2012.

HOBBS, R. J.; Effects of landscape fragmentation on ecosystem processes in the Western Australian Wheatbelt; Biological Conservation; v. 64; p. 193-201; 1993.

KLINK, C. A.; MACHADO, R.; A conservação do Cerrado brasileiro. Megadiversidade; v. 1, n.1, p. 147-155, Belo Horizonte-MG; 2005.

LANG, S.; TIEDE, D.; vLATE Extension für ArcGIS - vektorbasiertes Tool zur quantitative Landschaftsstrukturanalyse. http://downloads2.esri.com/campus/uploads/library/pdfs/68464.pdf.; 2003; Acessado em 10 de maio de 2016.

LINDENMAYER, D. B.; FISCHER, J.; Habitat fragmentation and landscape change: an ecological and conservation synthesis; Washington D.C.: Island Press; p. 328; 2006.

LINDENMAYER, D. B.; A checklist for ecological management of landscapes for conservation; Ecology Letters, Oxford, v. 11, n. 1, p. 78-91, 2008.

LIU, S.; DONG, Y.; DENG, L.; LIU, Q.; ZHAO, H.; DONG, S.; Forest fragmentation and landscape connectivity change associated with road network extension and city expansion: A case study in the Lancang River Valley; Ecological Indicators; v. 36; p. $160-168 ; 2014$.

LLAUSÀS, A.; NOGUÉ, J.; Indicators of landscape fragmentation: The case for combining ecological indices and the perceptive approach; Ecological Indicators v. $15: 1$, p. $85-91 ; 2012$.

LUCAS, D. F.; Análise Espacial dos Fragmentos Florestais no Município de São Gonçalo do Rio Abaixo/MG; Monografia - Universidade Federal de Minas Gerais UFMG; 2011.

MA, M.; HIETALA, R.; KUUSSAARI, M.; HELENIUS, J.; Impacts of edge density of field patches on plant species richness and community turnover among margin habitats in agricultural landscapes; Ecological Indicators; v. 31; p. 25-34; 2013.

MAZEROLLE, M. J.; Amphibian road mortality in response to nightly variations in traffic intensity; Herpetologica; v. 60, p. 45-53; 2004.

MORTELLITI, A.; WESTGATE, M. J.; LINDENMAYER, D. B; Experimental evaluation shows limited influence of pine plantations on the connectivity of highly fragmented bird populations; Journal of Applied Ecology; v. 51; p. 1179-1187; 2014.

OLIVEIRA, S. N.; Análise das mudanças espaciais e temporais nos padrões de paisagem na Região do Oeste da Bahia sobre a formação do Grupo Urucuia (19882011) e suas implicações para a conservação do cerrado; Tese de Doutorado; Universidade de Brasília - UnB; 2015. 
OLIVEIRA, S.N.; CARVALHO, O. A.; GOMES, R. A. T.; GUIMARÃES, R. F.; MCMANUS, C. M.; Landscape-fragmentation change due to recent agricultural expansion in the Brazilian Savanna, Western Bahia, Brazil; Reg Environ Change; 2016.

Organização das Nações Unidas para a Educação, a Ciência e a Cultura UNESCO; Vegetação do Distrito Federal : tempo e espaço; $2^{\circ}$ Edição; 80p; Brasília - DF; 2002

OSTAPOWICZ, K.; VOGT, P.; RIITTERS, K. H,; KOZAK, J.; ESTREGUIL, C.; Impact of scale on morphological spatial pattern of forest; Landscape Ecol; 2008.

PAVIANI, A.. Brasília no contexto local e regional: Urbanização e crise. Revista Território - Ano VII - no 11, 12 e 13 - set./out., Rio de Janeiro, 2003.

PEREIRA, J.L.G.; BATISTA, G.T.; THALÊS, M.C.; ROBERTS, D.A.; VENTURIERI, A. Métricas da paisagem na caracterização da evolução da ocupação da Amazônia. Geografia, v.26, n.1, p.59-90, 2001.

PINTO, J. R. R.; LENZA, E.; PINTO, A. S.; Composição florística e estrutura da vegetação arbustivo-arbórea em um cerrado rupestre, Cocalzinho de Goiás, Goiás; Revista Brasileira de Botânica, v. 32, p. 1-10, 2009.

PRIMACK, R. B.; RODRIGUES, E. Biologia da conservação. Londrina: Viva; p. 328; 2001.

REMPEL R.S.; KAUKINEN D.; CARR A.P.; Patch Analyst and Patch Grid; Ontario Ministry of Natural Resources; Centre for Northern Forest Ecosystem Research, Thunder Bay, Ontario; 2012.

SAMPAIO, M.; Oeste da Bahia Capitalismo, Agricultura e Expropriação de Bens de Interesse Coletivo; Anais do XXI Encontro Nacional de Geografia Agrária; Universidade Federal de Uberlândia - UFU; Uberlândia - MG; 2012.

SANTOS, A. A.; MACHADO, M. M. M.; Análise da Fragmentação da Paisagem do Parque Nacional da Serra da Canastra e de sua Zona de Amortecimento - MG. RA'E GA: o Espaço Geográfico em Análise, v. 33, p. 75-93, 2015.

SAURA, S; VOGT, P; VELÁZQUEZ, J; HERNANDO, A; TEJERA, R; Key structural forest connectors can be identified by combining landscape spatial pattern and network analyses; Forest Ecology and Management; 2011.

SILVA, W. G.; METZGER, J. P.; SIMÕES, S. B.; Relief influence on the spatial distribution of the Atlantic Forest cover at the Ibiúna Plateau, SP; Brazilian Journalof Biology; Rio de Janeiro, v. 67, n. 3, p. 403-411, 2007.

SILVA, M. S. F., SOUZA, R. M.; Padrões Espaciais de Alterações da Paisagem na Floresta Nacional do Ibura, Sergipe, Brasil; Mercator; v. 13, n. 3, p. 121-137; Universidade Federal do Ceará - UFC; Fortaleza - CE; 2014.

SOILLE, P.; VOGT, P.; Morphological segmentation of binary patterns; Pattern Recognit Lett; 2009. 
SOUZA, C. G.; ZANELLA, L. ; BOREM, R. A. T. ; CARVALHO, L. M. T. ; ALVES, H. M. R. ; VOLPATO, M. M. L.; Análise da Fragmentação da paisagem da Área de Proteção Ambiental Coqueiral, Coqueiral - MG; Ciência Florestal; v. 24, p. 631-644, 2014.

SUN, J., SOUTHWORTH, J. Indicating structural connectivity in Amazonian rainforests from 1986 to 2010 using morphological image processing analysis, International Journal of Remote Sensing; 2013.

VOGT, P.; RIITTERS, K. H.; ESTREGUIL, C.; KOZAK, J.; WADE, T. G.; WICKHAM, J. D.; Mapping spatial patterns with morphological image processing; Landsc Ecol; 2007. 


\section{CAPITULO 4 - CONSIDERAÇÕES FINAIS}

O presente estudo possibilitou o conhecimento das alterações ocorridas pela ação humana na APA do Rio São Bartolomeu desde a sua criação até os dias atuais, reunindo informações com potencial em auxiliar o planejamento e controle deste espaço protegido.

Em geral, as gestões das unidades de conservação são de responsabilidade do poder público com participação da sociedade civil. Tal processo resguarda uma serie de desafios, deixando por vezes em segundo plano os reais objetivos de cada unidade, pois as prioridades são ocupadas por questões politicas e administrativas, como o controle da pressão urbana, ocupação desordenada, avanço sobre a vegetação nativa e regularização fundiária (quando couber).

Não diferente das demais UCs, a APA do Rio São Bartolomeu passa por tantos desses problemas, ainda que seja uma unidade de uso sustentável, ou seja, que permita a coexistência com as ações humanas. No entanto, o descontrole do avanço das atividades humanas é tão intenso, que por vezes a existência da área protegida é ignorada.

Neste trabalho foi possível constatar a fragilidade da unidade de conservação frente às pressões econômicas e especulação fundiária. Ao perder $15.775,83$ ha de área nativa, que representam $18,80 \%$ da unidade, é constatado o afastamento do poder público e gestão da unidade no período estudado. Aqui não se diz que há um abandono do poder público, mas é possível afirmar que as ações educacionais ou de controle não chegam à comunidade local.

É relevante a atualização das normas de zoneamento, partindo da Lei Distrital № 1.149/1996 para a Lei Distrital № 5.344/2014, destacando o aumento de 45,86\% da área de maior restrição ambiental na unidade, resguardando $72,80 \%$ da vegetação natural existente em 2014. No entanto, questiona-se a exposição de 6.033,82ha $(21,44 \%)$ da vegetação nativa em Macrozona Urbana (Lei Complementar o 803/09 - DF), permitindo a implementação de empreendimentos urbanos que poderão ser instalados neste espaço.

Além da vegetação nativa, a análise da mudança de cobertura da terra permitiu o conhecimento da dinâmica de classes que também são importantes para a gestão pública. $O$ trabalho demonstrou que durante o período estudado, ainda que não houvesse grande variação nos espaços ocupados com atividades agrossilvipastoris as áreas alteradas registraram um aumento de 58,84\%, 
interferindo em áreas antes ocupadas por vegetação natural e agricultura, precedendo o uso urbano quando do aumento desta classe.

Através dos resultados da dinâmica das modificações impostas no uso e cobertura da terra, foi possível analisar a fragmentação da paisagem da unidade de conservação, com vistas aos remanescentes de vegetação natural. Neste ponto, além da intensa fragmentação dos remanescentes nativos, foi possível constatar a característica de ocupação desordenada e gradual, sinalizado com o aparecimento de perfurações anteriores ao desaparecimento dos fragmentos.

Frente aos desafios para a gestão de áreas protegidas e a implementação da Lei Federal 12.6561/2012, fica evidenciado que as técnicas utilizadas por esta dissertação são importantes para a correta e justa tomada de decisões. Ademais, na observação de instrumentos como o CAR e o PRA, é possível por exemplo se valer de tais metodologias para enquadrar quais imóveis mantém atividades agrossilvipastoris anteriores a 22 de julho de 2008, assim como direcionar uma correta definição das reservas legais através da visualização dos corredores ecológicos existentes.

O conjunto de técnicas adotadas por esta dissertação se mostram úteis e necessárias para o planejamento, monitoramento e controle na gestão dos territórios. Diante das técnicas disponíveis e previsões legais, a gestão de uma unidade de conservação apenas será eficiente quando nortear o planejamento em resultados obtidos por técnicas que compreendam as mudanças espaço-temporais dos padrões de paisagem, aliando com politicas públicas que alcancem a população local e sejam efetivas no controle do que ameaça o rezoneamento e demais normas de ordenamento. 